PRZEGLĄD NAUK HISTORYCZNYCH 2016, R. XV, NR 2

http://dx.doi.org/10.18778/1644-857X.15.02.05

ZBigniew ANusiK

UNIWERSYTET ŁÓDZKI

\title{
Książęta Jerzy i Krzysztof Zbarascy wobec problemów poludniowo-wschodniego pogranicza Rzeczypospolitej w drugim i trzecim dziesięcioleciu XVII wieku
}

Streszczenie. Książęta Jerzy i Krzysztof Zbarascy byli potomkami starej i ogromnie bogatej rodziny magnackiej. Ich wykształcenie, majątek i walory umysłowe predestynowały ich do odgrywania ważnej roli na arenie politycznej. Niechęć ze strony Zygmunta III sprawiła jednak, że obaj bracia znaleźli się w szeregach opozycji. Jako właściciele wielkich majątków na kresach, książęta z natury rzeczy musieli być zainteresowani zarówno sytuacja na Ukrainie, jak i stosunkami $z$ państwami graniczącymi $w$ tym regionie $z$ Rzecząpospolitą. $\mathrm{W}$ połowie drugiego dziesięciolecia XVII $\mathrm{w}$. popadli $\mathrm{w}$ konflikt $\mathrm{z}$ hetmanem Stanisławem Żółkiewskim. Uważali bowiem, że polityka hetmana na kresach prowadzi do wojny $z$ Turcją. Zbarascy opowiadali się natomiast za utrzymaniem pokoju z sułtanem. Swojego stosunku do państwa Imperium Osmańskiego nie zmienili do końca życia. Utrzymanie pokojowych stosunków z Turcją uważali za jeden $z$ priorytetów polityki zagranicznej Rzeczypospolitej. Na kwestię stosunków $z$ Chanatem Krymskim książęta Zbarascy patrzyli przez pryzmat polityki tureckiej. Władców Krymu uważali za wykonawców polityki Stambułu i narzędzie służące sułtanom do wywierania nacisku na Rzeczpospolita. Opowiadali się za tym, by nie prowokować Tatarów. Brali jednak czynny udział w zwalczaniu najazdów tatarskich. W walce $z$ Tatarami gotowi byli wykorzystać pomoc Kozaków. W latach 1624-1628 bracia Zbarascy poparli pomysł interwencji w wewnętrzne sprawy Chanatu Krymskiego. Uważali bowiem, że podsycanie wojny domowej na Krymie będzie pod każdym względem korzystne dla interesów Rzeczypospolitej.

Bardzo ciekawy był też stosunek braci Zbaraskich do Kozaczyzny. Obaj książęta uważali Kozaków za buntowników, burzycieli porządku wewnętrznego i awanturników prowokujących konflikty $z$ Turcją. Nie akceptowali polityki pobłażania Kozakom w okresie przed Cecorą. Po Chocimiu nakłaniali Kozaków

* Wydział Filozoficzno-Historyczny, Instytut Historii, Katedra Historii Nowożytnej. 
do zaprzestania wypraw na Morze Czarne. Obaj bracia bardzo szybko dostrzegli niebezpieczeństwo, jakie stanowił sojusz prawosławnych władyków z Kozaczyzną. Uznali go za poważne zagrożenie dla interesów Rzeczypospolitej na Ukrainie. Książęta Zbarascy odnosili się do mołojców z poczuciem wyższości i z pogarda. Doceniali jednak siłę wojskową Kozaczyzny. Bracia Zbarascy opowiadali się za polityką twardej ręki wobec Kozaków. Książę Jerzy wielokrotnie powtarzał, że na Kozaków nie trzeba żadnych komisji, tylko szabli. Niemniej książęta ze Zbaraża czuli respekt przed liczna i bitna armią kozacką. Bali się zniszczenia swoich majątków. Po zawarciu ugody kurukowskiej opowiedzieli się jednak za rygorystycznym przestrzeganiem jej warunków. Stosunkowo niewiele uwagi poświęcali natomiast Zbarascy sytuacji w księstwach naddunajskich - Mołdawii i Wołoszczyźnie. Śledzili zaś poczynania władcy Siedmiogrodu - Bethlena Gabora. Paradoksem wydaje się to, że po śmierci Krzysztofa, kiedy został najpotężniejszym latyfundystą na kresach Rzeczypospolitej, Jerzy ks. Zbaraski w dużo mniejszym stopniu interesował się sytuacja $\mathrm{w}$ tamtym regionie. Jego uwagę absorbowały bowiem $\mathrm{w}$ tym czasie zupełnie inne problemy. Warto w tym kontekście zaznaczyć, że również wcześniej problematyka pogranicza południowo-wschodniego nie stanowiła bynajmniej głównego przedmiotu zainteresowania braciZbaraskich. Byli oni bowiem politykami, którzy próbowali wpływać na całokształt tak wewnętrznej, jak i zagranicznej polityki państwa, śledząc i komentując na bieżąco wszystkie najistotniejsze wydarzenia, które rozgrywały się w Europie Środkowo-Wschodniej w drugim i trzecim dziesięcioleciu XVII w.

Słowa kluczowe: Rzeczpospolita w pierwszej połowie XVII w., pogranicze południowo-wschodnie, Jerzy ks. Zbaraski, Krzysztof ks. Zbaraski, Zygmunt III, Turcja, Tatarzy, Kozacy.

$\mathrm{J}$ erzy (1574-1631) i Krzysztof (1579-1627) ks. Zbarascy byli potomkami starego wołyńskiego rodu kniaziowskiego, który jednak dopiero za panowania ostatniego z Jagiellonów zaczą odgrywać poważniejszą rolę polityczną w Wielkim Księstwie Litewskim, a następnie (po unii lubelskiej) w całej Rzeczypospolitej. Prawdziwym twórca majątkowej i politycznej potęgi kniaziów na Zbarażu był dopiero ojciec obu książąt - wojewoda bracławski Janusz (zm. 1608). Książę-wojewoda $z$ niebywała wprost konsekwencja powiększał swój stan posiadania i u schyłku życia władał już wielkimi i dobrze zagospodarowanymi dobrami zarówno na Wołyniu, jak i na Ukrainie. Nie wchodząc w szczegóły, należy przyjąć, że na przełomie XVI i XVII stulecia w rękach Janusza ks. Zbaraskiego znajdowały się prywatne majątki, w skład których wchodziło co najmniej 190 miast, miasteczek i wsi. W 1572 r. książę Janusz ożenił się z kniaziówna Anną Czetwertyńska (zm. 1581), która po bezpotomnej śmierci jedynego brata (kniazia Janusza Czetwertyńskiego) odziedziczyła rozległe dobra ziemskie na Wołyniu i w województwie bracławskim. Dwaj synowie Janusza i Anny, Jerzy i Krzysztof 
ks. Zbarascy byli jedynymi spadkobiercami całej ogromnej fortuny zgromadzonej przez wojewodę bracławskiego. Od dzieciństwa wychowani w wierze katolickiej, obyci w świecie, wykształceni i oczytani, pod względem intelektualnym zdecydowanie przewyższali ojca. Przesiąknięci kulturą zachodnią, bardzo aktywni w życiu politycznym, osiagnęli w Rzeczypospolitej znaczenie, o którym nie mógł marzyć wojewoda bracławski. W przeciwieństwie do księcia Janusza, jego synowie nie poświęcali już tak wiele uwagi swoim dobrom ukraińskim. Nie oznacza to jednak, że nie troszczyli się o sprawy majątkowe. Wręcz przeciwnie, sądzić można, że w tym zakresie wykazywali wiele podobieństw do ojca ${ }^{1}$.

Swoje wielkie znaczenie polityczne i niezwykła popularność wśród szlachty bracia Zbarascy zawdzięczali nie tylko niewattpliwym talentom osobistym ${ }^{2}$, lecz także ogromnemu majatkowi. Obaj okazali się zreszta bardzo rządnymi gospodarzami i wykazywali wielka dbałość o powiększenie odziedziczonych po ojcu dóbr ziemskich. O ile jednak książę Janusz interesował się przede wszystkim nabytkami na kresach, o tyle Jerzy i Krzysztof ks. Zbarascy zwrócili większą uwagę na ziemie leżące na zachód od ich rodzinnego Wołynia. $Z$ biegiem czasu obaj uzyskali nadania licznych królewszczyzn na Rusi oraz na etnicznych ziemiach polskich ${ }^{3}$. Do dóbr domeny

${ }^{1}$ Por. J. Wolff, Kniaziowie litewsko-ruscy od końca XIV wieku, Warszawa 1895, s. 616-617; A. Boniecki, Poczet rodów w Wielkiem Księstwie Litewskim w XV i XVI wieku, Warszawa 1887, s. 412, 416; Z. Anusik, Latyfundia ksiażąt Zbaraskich w XVI i XVII wieku, „Przegląd Nauk Historycznych” 2009, R. VIII, nr 1, s. 19-25, 34-51; i d e m, Zbarascy i Kalinowscy. Karta z dziejów wielkiej własności ziemskiej na kresach Rzeczypospolitej w pierwszej połowie XVII wieku, [w:] Miedzy Zachodem a Wschodem, t. III (Etniczne, kulturowe i religijne pogranicza Rzeczypospolitej $w$ XVI-XVIII wieku), red. K. Mikulski i A. Zielińska-Nowicka, Torun 2006, s. 75-89; id e m, Kasztelan krakowski Jerzy ks. Zbaraski (1574-1631). Szkic do portretu antyregalisty, „Przegląd Nauk Historycznych” 2010, R. IX, nr 1, s. 55-58; W. Dobrowolska, Młodość Jerzego i Krzysztofa Zbaraskich ( $Z$ wstępem o rodzie Zbaraskich i życiorysem Janusza Zbaraskiego wojewody bracławskiego), Przemyśl 1927, s. 51-52, 53, 55, 57-63, 86-103, 121-134; e ade m, Ksiązęta Zbarascy $w$ walce $z$ hetmanem Źółkiewskim, Kraków 1930, passim; J. M o r zy, Kryzys demograficzny na Litwie i Białorusi w II połowie XVII wieku, Poznań 1965, s. 181, 333.

${ }^{2}$ Obaj bracia odznaczali się wielkim dowcipem, przechodzacym czasami w sarkazm, oraz niepospolita wymową. Byli także znanymi i cenionymi publicystami. Głośna była też sława ich licznych zagranicznych podróży oraz gruntownego i wszechstronnego wykształcenia. Por. W. Dobrowols ka, Młodość..., s. 133-134.

${ }^{3}$ Jerzy ks. Zbaraski był starosta pińskim, radohoskim, sokalskim, żarnowieckim i wiślickim (dostał to starostwo po śmierci brata). Użytkował też dobra krzesłowe kasztelanii krakowskiej i tenutę szycką. W królewszczyznach miał w sumie 
królewskiej rychło dodali też prywatne dobra w Małopolsce. Jerzy kupił Pilicę i Łodygowice w Krakowskiem ${ }^{4}$, a Krzysztof Końskowolę w Lubelskiem ${ }^{5}$. W Krakowie posiadali piękną, renesansową kamienicę (zwana pałacem), która stała się ich ulubiona rezydencją. Nie na Wołyniu i na Ukrainie, ale właśnie w Małopolsce najczęściej też przebywali ${ }^{6}$.

osiem miast i przynajmniej 166 wsi. Orientacyjny wymiar kwarty z tych dóbr domeny wynosił 5503 złote. Por. J. Wolff, op. cit., s. 618; A. Boniecki, op. cit., s. 412-413; K. Chła pow ski, Realizacja reform egzekucji dóbr 1563-1665. Sprawa zniesienia zastawów królewszczyzn małopolskich, Warszawa 1984, s. 211, 221; i d e m, Elita senatorsko-dygnitarska Korony za czasów Zygmunta III i Władysława IV, Warszawa 1996, s. 99; Z. An u sik, Zbarascy..., s. 89; id e m, Latyfundia..., s. 54-55; idem, Kasztelan..., s. 58-59; ide m, Kariery faworytów królewskich a kariery opozycjonistów $w$ dobie panowania Zygmunta III (1587-1632), „Przegląd Nauk Historycznych” 2004, R. III, nr 2 (6), s. 52-53. Krzysztof ks. Zbaraski był starostą krzemienieckim, bolesławskim (krótko w 1615 r.), soleckim, wiślickim i hrubieszowskim. W sumie użytkował pięć miast i 70 wsi królewskich, z których opłacał 5659 złotych kwarty. Por. K. Chłapowski, Elita..., s. 84, 99-100, 122; id e m, Realizacja..., s. 221; id e m, Starostowie w Małopolsce 1565-1668, [w:] Społeczeństwo staropolskie, t. IV, red. A. Izydorczyk i A. Wyczański, Warszawa 1986, s. 131, 133, 139, 150; A. Boniecki, op. cit., s. 412; J. Wolff, op. cit., s. 618; Z. Anu sik, Zbarascy..., s. 89; id em, Latyfundia..., s. 53-55; idem, Kariery..., s. 52-54; id e m, Kasztelan..., s. 59.

${ }^{4}$ Miasta Pilicę i Mrzygłód z 15 całymi wsiami i trzema częściami wsi wchodzącymi w skład „hrabstwa” pilickiego kupił książę Jerzy Zbaraski już w 1613 r. od Padniewskich. Dominium Łodygowice (cztery wsie) odkupił w 1618 r. od Krzysztofa Rarowskiego, który przeją ten majątek za długi poprzedniego właściciela - Mikołaja Komorowskiego, ale obawiał się, że nie zdoła utrzymać go w swoich rękach. Por. Z. Anu sik, Zbarascy..., s. 89-90; id e m, Latyfundia..., s. 55; id e m, Kasztelan..., s. 59; Rejestr poborowy województwa krakowskiego z roku 1629, oprac. W. Domin, J. Kolasa, E. Trzyna, S. Żyga, red. S. Inglot, Wrocław 1956, s. 170-171, 175, 183-184, 190-191; A. Grusze cki, Zamki bastionowe w Małopolsce, Warszawa 1962, s. 144, 187; J. W iśn n i w s ki, Historyczny opis kościołów, miast, zabytków i pamiatek w Olkuskiem, Mariówka 1933, s. 280; W. D o b r o w o1ska, Młodość..., s. 207; A. Przy boś, Komorowski Mikołaj z Komorowa, [w:] Polski słownik biograficzny [dalej: PSB], t. XIII, Wrocław 1967-1968, s. 427.

${ }^{5}$ Krzysztof ks. Zbaraski wszedł $\mathrm{w}$ posiadanie klucza końskowolskiego (miasto i 21 wsi) około roku 1617. Dobra te przejał od zadłużonego u niego (dług w wysokości 160 tys. złotych) wojewody lubelskiego Gabriela Tęczyńskiego. Por. R. Szczygieł, Od lokacji do upadku szlacheckiej Rzeczypospolitej, [w:] Dzieje Końskowoli, red. R. Szczygieł, Lublin 1988, s. 41-42; Z. Anu sik, Kasztelan..., s. 59-60; Rejestr poborowy województwa lubelskiego (powiat lubelski i urzędowski z r. 1626, ziemia łukowska z r. 1620), oprac. J. Kolasa i K. Schuster, red. S. Inglot, Wrocław 1957, s. 136-139.

${ }^{6}$ Por. W. Dobrowolska, Młodość..., s. 207. Ulubiona rezydencja Krzysztofa stała się Końskowola. Dokonał on również gruntownej przebudowy starościńskiego zamku w Solcu nad Wisła. Jerzy ks. Zbaraski wszedł z kolei w posiadanie świeżo 
Jerzy i Krzysztof ks. Zbarascy początkowo wspólnie zarządzali swoimi dobrami na Wołyniu i Ukrainie. W drugim dziesięcioleciu XVII w. (bliższej daty nie udało się niestety ustalić) dokonali jednak formalnoprawnego podziału spadku po ojcu. Krzysztof wziął wówczas w Bracławszczyźnie Pohrebyszcze i Daszów, wszystkie dobra kijowskie (Wołodarka, Antonów, Rozwołoż, Bereznia, Irhaczów, Torczyca, Borszczajówka) oraz połowę Zbaraża i dóbr wołyńskich ${ }^{7}$. Pozostałe dobra bracławskie (Niemirów, Przyłuka, Ładyżyn, Berszada i szereg innych) oraz połowa Zbaraża i dziedzicznych majątków ziemskich na Wołyniu przypadły natomiast w udziale Jerzemu ${ }^{8}$. Każdy $z$ braci na własny już rachunek dokonał też wspomnianych

wybudowanego przez Wojciecha Padniewskiego zamku (pałacu) w Pilicy. Wkrótce po nabyciu klucza pilickiego Zbaraski rozpoczął rozbudowę swojej nowej rezydencji. Do końca życia nie zdołał jednak zakończyć tej inwestycji. Wspólnym dziełem obu braci była natomiast przebudowa pałacu w Krakowie, zrealizowana przez flamandzkiego architekta Henrika van Peene w latach 1620-1631. Por. Z. An usik, Latyfundia..., s. 56; i d e m, Kasztelan..., s. 60; R. Szczy gi ieł, op. cit., s. 42; S. Starowolski, Polska albo opisanie położenia Królestwa Polskiego, wyd. A. Piskadło, Kraków 1976, s. 81 (tu błędnie przypisano przebudowę zamku w Solcu Krzysztofowi Zborowskiemu zamiast Zbaraskiemu); W. Czapliński, J. Długosz, Życie codzienne magnaterii polskiej $w$ XVII wieku, Warszawa 1976, s. 13; H. Kowa1ska, Padniewski Wojciech, [w:] PSB, t. XXV, Wrocław 1980, s. 8; J. W iśn niew ski, op. cit., s. 279-280, 295-297; A. Gruszecki, op. cit., s. 144; A. Miłobędzki, Architektura polska XVII wieku, t. I, Warszawa 1980, s. 252.

${ }^{7} \mathrm{Na}$ podstawie zachowanych rejestrów poborowych dla Wołynia i dwóch województw ukrainnych możemy przyjać, że pod koniec życia Krzysztof ks. Zbaraski miał około 8300 dymów w województwie bracławskim, 2670 dymów w województwie kijowskim oraz 2600 dymów w województwie wołyńskim. Łącznie więc w swoich dobrach na Wołyniu i Ukrainie posiadał około 13600 gospodarstw chłopskich i mieszczańskich. Por. H. Litwin, Napływ szlachty polskiej na Ukraine 1569-1648, Warszawa 2000, s. 45; Z. A nu sik, Struktura społeczna szlachty bracławskiej $w$ świetle rejestru podymnego z 1629 roku, „Przegląd Historyczny” 1985, t. LXXVI, z. 2, s. 237-238; idem, Szlachta polska na Ukrainie $w$ latach 1569-1648. Kilka uwag na marginesie ksiażki Henryka Litwina, „Przegląd Nauk Historycznych” 2002, R. I, nr 2, s. 237; ide m, Latyfundia..., s. 64-65; idem, Kasztelan..., s. 60-61; O. B a ra n ow y c z, Zaludnienija wołynskogo wojewodstwa $w$ pierszij połowyni XVII st., Kyjw 1930, s. 25, 56, 98-100, 102-103; Źródła dziejowe, t. XX (Polska XVI wieku pod względem geograficzno-statystycznym, t. IX, Ziemie ruskie. Ukraina [Kijów-Bracław]), wyd. A. Jabłonowski, Warszawa 1894, s. $132,133,135,138$.

${ }^{8}$ U schyłku trzeciego dziesięciolecia XVII w. Jerzy ks. Zbaraski miał prawie 11000 dymów w województwie bracławskim oraz około 2600 dymów na Wołyniu. Podobnie jak młodszy brat był więc właścicielem około 13600 gospodarstw chłopskich i mieszczańskich. Por. H. Litwin, op. cit., s. 45; Z. Anu sik, Struktura..., s. 237-238; idem, Szlachta..., s. 237; idem, Latyfundia..., s. 65; id e m. Kasztelan..., s. 61; O. Baranowycz, op. cit., s. 25, 98-100, 102-103. 
zakupów dóbr w Małopolsce. Ich wspólną własnością pozostał natomiast zamek w Zbarażu i pałac w Krakowie. Po uwzględnieniu użytkowanych przez Zbaraskich dóbr domeny królewskiej śmiało można powiedzieć, że każdy $z$ nich należał do grona najzamożniejszych magnatów koronnych pierwszej połowy XVII w. Już w listopadzie 1620 r. potężny magnat litewski - Lew Sapieha, krytykując Zbaraskich za zbyt małe, jego zdaniem, zaangażowanie w przygotowanie kraju do obrony przed najazdem tureckim, $z$ pewna przesada napisał: „Książęta Zbarascy, wielcy panowie, od KJM więcej mają [dostatków - przyp. Z.A.], a nie stawiają więcej jeno 200 koni Kozaków i 200 piechoty"'.

Potęga majątkowa ostatnich książąt Zbaraskich była bez wątpienia jednym $z$ istotnych czynników wpływających na ich pozycję polityczną. Ogromna popularność wśród szlachty zawdzięczali jednak bracia Zbarascy przede wszystkim swojej działalności publicznej i prezentowanym przez siebie poglądom. Starszy z nich - książę Jerzy - był $z$ pewnościa najwybitniejszym przywódca antykrólewskiej opozycji w drugiej połowie panowania Zygmunta III. Od początku swojej kariery politycznej Jerzy ks. Zbaraski ściśle współpracował ze swoim młodszym bratem Krzysztofem. Ten ostatni, wszechstronnie wykształcony, władający kilkoma obcymi językami, należał bezsprzecznie do grona najciekawszych postaci sceny politycznej Rzeczypospolitej drugiego i trzeciego dziesięciolecia XVII w. Służył krajowi na polach bitew, uczestniczył w sejmach i sejmikach, sprawował ważne misje dyplomatyczne ${ }^{10}$. Początkowo nic nie wskazywało na to, że książęta ze Zbaraża staną się w przyszłości przywódcami antykrólewskiej opozycji. Po śmierci ojca bracia Zbarascy starali się bowiem pozyskać łaskę Zygmunta III. Obaj wzięli też udział w wyprawie smoleńskiej. W nagrodę za udział w wojnie

${ }^{9}$ Lew Sapieha do Jana Stanisława Sapiehy, Warszawa 15 XI 1620, cyt. za: A. Filipczak-Kocur, Contra majestatem czy pro publico bono? Jerzy Zbaraski, kasztelan krakowski 1621-1631, [w:] Faworyci i opozycjoniści. Król a elity polityczne $w$ Rzeczypospolitej XV-XVIII wieku, red. M. Markiewicz i R. Skowron, Kraków 2006, s. 267.

10 Por. W. Chomętowski, Książe Krzysztof Zbaraski, koniuszy koronny, „Biblioteka Warszawska” 1865, t. III, s. 1-14, 424-428, t. IV, s. 142-174, 451-509; A. Filipczak-Kocur, Ksiaże Krzysztof Zbaraski (1579-1627). Szkic biograficzny, [w:] Korespondencja księcia Krzysztofa Zbaraskiego koniuszego koronnego 1612-1627, oprac. A. Filipczak-Kocur, Opole 2015, s. 9-80; Z. Anusik, Cztery listy księcia Krzysztofa Zbaraskiego do prymasa Wawrzyńca Gembickiego z lat 1620-1623, „Przegląd Historyczny” 1991, t. LXXXII, z. 3-4, s. 469; id e m, Kariery..., s. 53; W. Do b row ols ka, Młodość..., s. 207-208, e a d e m, Książęta..., s. 6-9. 
moskiewskiej król obdarzył w 1610 r. Krzysztofa urzędem koniuszego wielkiego koronnego, a Jerzego wyniósł w roku 1612 do godności krajczego koronnego ${ }^{11}$.

W kolejnych latach książe Jerzy, który z racji swojego urodzenia, zajmowanej pozycji społecznej, majątku i wykształcenia czuł się predestynowany do odgrywania czołowej roli politycznej w kraju, $z$ coraz większą niechęcia spoglądał na poczynania Zygmunta III. Król $z$ kolei nie śpieszył się $z$ obdarzeniem ambitnego magnata jakimś wyższym urzędem lub też nadaniem mu jakiegoś wakującego starostwa. Przeciwko Zbaraskiemu intrygowali zreszta skutecznie dworzanie królewscy i jezuici. Na jego niekorzyść działały też wyrażane przez niego opinie. Jak słusznie zauważyła Wanda Dobrowolska: „Tolerant i wróg jezuitów, wróg Austrii, do której niechęć powoli wzrastała, Jerzy Zbaraski coraz mocniej przekonywał się o niemożności przerobienia kursu polityki Zygmuntowej, coraz więcej rozgoryczał"12. Jest sprawą oczywista, że książęta ze Zbaraża, właściciele ogromnych dóbr ziemskich na Wołyniu i Ukrainie, ze szczególna uwagą obserwowali sytuację na południowo-wschodnich kresach Rzeczypospolitej. Ich niezadowolenie $z$ polityki państwa w tym regionie spowodowało, że już wkrótce mieli przejść do otwartej opozycji wobec Zygmunta III.

W drugiej połowie drugiego dziesięciolecia XVII w. bracia Zbarascy uwikłali się $\mathrm{w}$ głośny konflikt $\mathrm{z}$ faworyzowanym $\mathrm{w}$ tym czasie przez króla wojewodą kijowskim i hetmanem polnym koronnym Stanisławem Żółkiewskim. Otwarcie oskarżali hetmana o nieudolność i obwiniali go za nieporządki panujace na kresach. Zbarascy mieli zresztą uzasadnione powody do niezadowolenia, gdyż ich wołyńskie i ukraińskie dobra były ustawicznie pustoszone przez Tatarów, z którymi Żółkiewski nie potrafił walczyć, Kozaków i bandy niepłatnego żołnierza. Mimo narastającej $z$ każdym rokiem niechęci do hetmana, Jerzy ks. Zbaraski przyprowadził w 1617 r. swoje nadworne choragwie (podobno aż 3000 ludzi) do obozu Żółkiewskiego. W czasie rokowań $z$ Turkami pod Busza książę Jerzy rozkazał spalić należące do niego miasteczko Berszadę, stanowiące punkt

${ }^{11}$ Por. J. Wolff, op. cit., s. 618; W. Polak, O Kreml i Smoleńszczyzne. Polityka Rzeczypospolitej wobec Moskwy w latach 1607-1612, Torun 1995, s. 197; Urzędnicy centralni i nadworni Polski XIV-XVIII wieku. Spisy, oprac. K. Chłapowski, S. Ciara, Ł. Kądziela, T. Nowakowski, E. Opaliński, G. Rutkowska, T. Zielińska, red. A. Gąsiorowski, Kórnik 1992, nr 248 i 293.

${ }^{12}$ W. Dobrowolska, Młodość..., s. 208. 
oparcia dla wypraw kozackich na Morze Czarne (zniesienie Berszady było jednym $z$ żądań tureckich). Otworzyło to drogę do pomyślnego sfinalizowania przez hetmana rozmów $z$ Iskanderem pasza (Skinderbasza) w dniu 23 września 1617 r. Sam traktat buszański (zawarty podobno przez Żółkiewskiego bez wiedzy i zgody obecnych w obozie panów kresowych), który pozbawiał Rzeczpospolita wszelkiego wpływu na sprawy księstw naddunajskich, wywołał jednak powszechne niezadowolenie i sprawił, że Zbarascy nie zaprzestali wrogich poczynań wobec starego hetmana ${ }^{13}$.

Niechęć obu braci do Żółkiewskiego wzrosła jeszcze bardziej w czasie obrad sejmu, który zebrał się w Warszawie 13 lutego 1618 r. Na tym właśnie sejmie Jerzy i Krzysztof ks. Zbarascy, uznani już w tym czasie przywódcy opozycji szlacheckiej, usiłowali wymóc na królu nadanie im wakujących godności (Jerzy aspirował do urzędu kanclerza wielkiego koronnego po Szczęsnym (Feliksie) Kryskim, a Krzysztof do podkomorstwa koronnego po Andrzeju Boboli). W tym celu zachęcali izbę poselską, aby zmusiła Zygmunta III do przestrzegania prawa o rozdawnictwie wakansów przed obradami sejmowymi. Spór o wakanse niemal sparaliżował obrady tego sejmu, gdyż posłowie twardo ponawiali swoje żądania, a król trwał $\mathrm{w}$ charakterystycznym dla siebie uporze. Wreszcie jednak ustapił i ku ogólnemu zaskoczeniu powierzył urząd kanclerza wielkiego koronnego staremu hetmanowi Stanisławowi Żółkiewskiemu, którego wcześniej, jeszcze przed rozpoczęciem obrad sejmu (6 lutego), mianował hetmanem wielkim koronnym. Co ciekawe, objęcie zwolnionego przez Żółkiewskiego urzędu wojewody kijowskiego zaproponował Zygmunt III Jerzemu ks. Zbaraskiemu. Ten jednak odmówił, gdyż nie uśmiechała mu się konieczność dłuższego pobytu na kresach (wojewoda kijowski był jednocześnie starosta grodowym w Kijowie). Być może odmowa przyjęcia przez księcia Jerzego najwyższego urzędu senatorskiego na ziemiach ruskich Korony uraziła Zygmunta III. W każdym razie po dłuższych przepychankach $z$ izbą poselska król rozdzielił pozostałe wakanse, w najmniejszym nawet stopniu nie uwzględniając zabiegów potężnych książąt. Podkanclerstwo koronne otrzymał bowiem przyjaciel Żółkiewskiego, biskup łucki Andrzej Lipski, buławę polną koronna protegowany i zięć hetmana, Stanisław Koniecpolski, a województwo kijowskie Tomasz

${ }^{13}$ Por. W. Dobrowolska, Książęta..., s. 917; Z. Os soliński, Pamiętnik, oprac. J. Długosz, Warszawa 1983, s. 83-91; A. Filipczak-Kocur, Contra..., s. 264-265; e a d e m, Książę..., s. 34-35. 
Zamoyski. Urząd podkomorzego koronnego pozostał nieobsadzony. Faworyzujac i dopuszczając do swojej łaski starego hetmana i jego politycznych przyjaciół, Zygmunt III niewątpliwie przyczynił się do dalszego zaognienia stosunków między Żółkiewskim a książętami ze Zbaraża. Zraził też do siebie tych ostatnich, co szybko dostrzegli ludzie $z$ najbliższego otoczenia monarchy. Jakub Zadzik wręcz twierdził, że pomijając w awansach Jerzego i Krzysztofa Zbaraskich, król stracił szansę na współpracę $z$ ludźmi ogromnie bogatymi i wywierajacymi istotny wpływ polityczny na szlachtę małopolską ${ }^{14}$.

Jeszcze w czasie sejmu 1618 r. Zbarascy wytoczyli szereg oskarżeń pod adresem Żółkiewskiego, zarzucając mu nieudolność i zaniedbanie interesów Rzeczypospolitej na pograniczu południowo-wschodnim. Domagali się także (zgodnie $z$ brzmieniem instrukcji sejmiku krakowskiego) zorganizowania wyprawy przeciwko Tatarom, ograniczenia władzy hetmana i zniesienia dożywotności tego urzędu. Sędziwy Żółkiewski musiał się usprawiedliwiać ze swego postępowania. W końcu też, dzięki poparciu ze strony innych regalistów, „zmusił do milczenia dąsającą się zazdrość” swoich przeciwników. W sumie jednak zwycięstwo partii dworskiej i hetmana na sejmie 1618 r. było tylko pozorne. Upór króla w sprawie rozdania wakansów sprawił bowiem, że posłowie odjechali z sejmu ogromnie rozjątrzeni, a ich niezadowolenie szybko rozszerzyło się na całą szlachtę $e^{15}$.

Wkrótce po zakończeniu sejmu, w obliczu nowego zagrożenia ze strony Turcji i Tatarów (spodziewano się odwetu za wyprawy kozackie $z$ lat 1617-1618), na dworze królewskim podjęto starania o pogodzenie braci Zbaraskich $z$ hetmanem Żółkiewskim. Zabiegi mediatorów (jednym $z$ nich był przyjaciel Krzysztofa - Tomasz

${ }^{14}$ Por. J. Seredyka, Sejm z 1618 roku, Opole 1988; W. Dobrowols ka, Ksiażęta..., s. 19-23; Z. Ossoliński, op. cit., s. 102-107 (tu na s. 106 znamienna opinia o dokonanych na sejmie nominacjach królewskich: „i w tym mały respekt na Rzeczpospolita majac, byle numerus w senacie był, o consilium jego nie dbajac, byle na urzędach byli ci, którzy by ad nutum wszystko czynili"); A. Filipczak- Kocur, Contra..., s. 263-266; J. Dorobisz, Jakub Zadzik (1582-1642), Opole 2000, s. 77; Z. Anusik, Kasztelan..., s. 65; E. Opaliński, Faworyci Zygmunta III a urzad podkomorzego koronnego, [w:] Faworyci..., s. 250; W. Ko n o p czyń ski, Chronologia sejmów polskich 1493-1793, Kraków 1948, s. 21 (147).

${ }_{15}$ Por. W. Dobrowolska, Ksiażęta..., s. 23-25; Instrukcja dana posłom na sejm z sejmiku przedsejmowego województwa krakowskiego w Proszowicach 2 stycznia 1618 r., [w:] Akta sejmikowe województwa krakowskiego [dalej: ASWK], t. I (1572-1620), wyd. S. Kutrzeba, Kraków 1932, s. 376; A. Filipczak-Kocur, Contra..., s. 265; J. Dorobisz, op. cit., s. 77. 
Zamoyski) przyniosły jednak dość ograniczone rezultaty. Co prawda obaj Zbarascy przybyli do obozu hetmana pod Orynin, ale podobnie jak inni możnowładcy kresowi, nie chcieli podporządkować się jego rozkazom. W efekcie spory i niesnaski w polskim obozie sparaliżowały działania całej armii. Ani Żółkiewski, ani też jego adwersarze nie wykazali jakiejkolwiek inicjatywy. Wojsko siedziało bezczynnie w obozie, a tymczasem Tatarzy rozpuścili zagony i spustoszyli ogromna połać bezbronnego kraju. Łupem rabusi padły liczne miasta i wioski na Wołyniu, Podolu i Ukrainie. Najbardziej ucierpiały majątki Zbaraskich, Sieniawskich, Ostrogskich, Zasławskich i Wiśniowieckich ${ }^{16}$. Rozgoryczony Krzysztof ks. Zbaraski pisał wkrótce po Oryninie (11 października 1618 r.) do kasztelana kaliskiego Rafała Leszczyńskiego: „Mnie Jampol, Ożochowce, wsi po tamtej stronie Krzemieńca w popiół obrócili, chłopy, szkapy cum omni generatione wybrali, nie zostało mi jedno kilka wiosek, caetera pustki. Co się zaś dzieje na krajnie [Ukrainie - przyp. Z.A.], bo środkiem majętności moich i brata mego pośli, do tego czasu wiadomości nie mam $z$ wielkim podziwieniem moim. Pan hetman do jakiegoś Żabińca poszedł mil 4 od Baru, tam posła od hospodara i od Skinder baszy przyjmować ma, który już poszedł z nadzieja fałszywego pokoju jako i sami przestrzegaja. Jest tam przy nim JMP starosta sandomierski $z$ ludźmi swoimi i moich dwanaścieset człowieka zostało. Jam tu swoich wołyńskich sług i piechoty nie mógł utrzymać i mnie już było trudno consiliis się bawić, gdzie res privata wszystka zginęła, raczej mi przyszło łatać te ostatki, niż móc ratować czeladź, którzy tak zostali jako na koniach siedzieli, żon, dzieci, majętności postradawszy. Bym ja był do tego przeklętego obozu nie chodził, mniej bym miał szkody, a więcej bym mógł sprawić, ale fata ducunt volentem, nollentem trahunt" ${ }^{17}$. Kompromitująca zarówno dla wodza, jak i dla jego wojska kampania orynińska ściagnęła gromy potępienia na Żółkiewskiego. Wiele wskazuje na to, że znaczna część anonimowych pism atakujących i szkalujących starego hetmana powstała $\mathrm{w}$ najbliższym otoczeniu braci Zbaraskich. Jest pewne, że niektóre $z$ tych pism były ich własnego

${ }^{16}$ Por. W. Dobrowolska, Ksiażęta..., s. 25-32; Z. Os soliński, op. cit., s. 110-112; W. Dwor za cze k, Hetman Jan Tarnowski. Z dziejów możnowładztwa małopolskiego, Warszawa 1985, s. 418-420; A. Filipczak-Kocur, Contra..., s. 265; ea de m, Ksią̇ę..., s. 35-36; Z. Anu sik, Kasztelan..., s. 66-67.

${ }^{17}$ Krzysztof Zbaraski do Rafała Leszczyńskiego, Białokrynica 11 X 1618, Korespondencja..., s. 89. Ten sam list por. W. Dobrowolska, Ksiażęta..., s. 38. 
autorstwa. Jest tė̇ sprawą oczywista, że bezpardonowe ataki na Źółkiewskiego tylko utwierdziły tego ostatniego w jego niechęci do dumnych książąt ${ }^{18}$.

Na kolejnym sejmie (22 stycznia - 5 marca 1619 r.) inspirowana i prowadzona przez Zbaraskich opozycja znowu wytoczyła zarzuty pod adresem hetmana. Żółkiewski ponownie musiał się tłumaczyć ze swojej bezczynności pod Oryninem. Rozgoryczony, zgłosił nawet gotowość złożenia buławy. Był to jednak jedynie pusty gest z jego strony, gdyż zarówno król, jak i senatorowie regaliści wystapili z goraca obrona jego zasług i dokonań. Podczas obrad sejmu 1619 r. powróciła sprawa wakansów (posłowie domagali się ich rozdania przed sejmem, a Zygmunt III zignorował te żądania). Nieustępliwość monarchy w tej drażliwej kwestii sprawiła, że opozycja zablokowała wysunięte przez dwór propozycje zorganizowania wielkiej wyprawy przeciwko Turkom i Tatarom (był to plan przedstawiony przez hetmana Żółkiewskiego), przeprowadzenia reformy podatkowej i znalezienia środków na obronę Inflant. Wiele czasu i energii posłowie poświęcili natomiast na próbę obciążenia duchowieństwa nadzwyczajnym podatkiem przeznaczonym na obronę kraju przed Tatarami. Ponieważ jednak w obronie stanu duchownego wystapił król i cała partia dworska, nie udało się zrealizować zamysłów kierowanej przez Zbaraskich szlachty. W tej sytuacji sejm 1619 r. rozszedł się bez podjęcia jakichkolwiek konstruktywnych uchwał ${ }^{19}$.

Mimo zdecydowanie opozycyjnej w owym czasie postawy Jerzego ks. Zbaraskiego, w trzy miesiące po zakończeniu sejmu (6 czerwca 1619 r.) Zygmunt III obdarzył go urzędem podczaszego koronnego. Radość obdarowanego nie była jednak zbyt wielka, gdyż godność tę książę Jerzy otrzymał po śmierci swojego przyjaciela, Adama Hieronima Sieniawskiego, wiernego od lat sojusznika Zbaraskich

18 Por. W. Dworzaczek, op. cit., s. 420; W. Dobrowolska, Ksią̇ęta..., s. 33-41; Z. Ossoliński, op. cit., s. 111-112; A. Filipczak-Kocur, Contra..., s. 265 (tu błędne stwierdzenie, że wydarzenia pod Oryninem „stały się inspiracja do artykułu w instrukcji województwa krakowskiego na sejm w roku 1618 na temat urzędu hetmana"). Warto bowiem przypomnieć, że do starcia $z$ Tatarami pod Oryninem doszło w końcu września 1618 r., a przywoływana instrukcja dla posłów krakowskich datowana jest na 2 I $1618 \mathrm{r}$.

${ }^{19}$ Por. J. Rzoń ca, Ostatni sejm przed Cecora (w roku 1619), „Pamiętnik Biblioteki Kórnickiej” 1983, z. 20, s. 5-91; W. Dobrowols ka, Książęta..., s. 41-46; A. Filipczak-Kocur, Contra..., s. 264; Z. Anusik, Kasztelan..., s. 67-68; Konstytucye seymu walnego koronnego warszawskiego roku P. 1619, [w:] Volumina legum [dalej: Vol. leg.], t. III, wyd. J. Ohryzko, Petersburg 1859, s. 169-175; W. Konopczyński, op. cit., s. 21 (147). 
w walce przeciwko hetmanowi Żółkiewskiemu. W kolejnych miesiącach książę Jerzy nie zmienił bynajmniej swoich poglądów i zdecydowanie potępiał politykę króla i hetmana. Za wielki błąd polityczny uważał próby mieszania się Rzeczypospolitej do wojny trzydziestoletniej i zabiegi Zygmunta III o odzyskanie Śląska. Bezwzględnie krytykował też pomoc króla dla Habsburgów zagrożonych przez wojska powstańców czeskich i sprzymierzonego z nimi władcy Siedmiogrodu Bethlena Gabora (Gabriela Bethlena). Ze szczególnym potępieniem ze strony księcia spotkało się jednak posłanie do Siedmiogrodu oddziałów lisowczyków, które pobiły pod Humiennem (23 listopada 1619 r.) korpus Jerzego Rakoczego i zmusiły Bethlena Gabora do odstąpienia od murów Wiednia. Kiedy zaś w początkach następnego roku wyparci z Siedmiogrodu lisowczycy wrócili do kraju i zaczęli rabować dobra szlacheckie w Małopolsce, Jerzy ks. Zbaraski wykorzystal niezadowolenie szlachty krakowskiej i podburzał ją przeciwko królowi i hetmanowi. Ostrzegał również, że pomoc udzielona cesarzowi może ściagnać na Rzeczpospolitą odwetową wyprawę turecka. W obliczu powszechnego niezadowolenia z polityki Zygmunta III, w roku 1620 bracia Zbarascy porozumiewali się $z$ innymi przywódcami magnackiej opozycji: kasztelanem krakowskim Januszem ks. Ostrogskim, kasztelanem wileńskim Januszem ks. Radziwiłłem, kasztelanem kaliskim Rafałem Leszczyńskim i hetmanem polnym litewskim Krzysztofem ks. Radziwiłłem. Nie zdołali jednak uzgodnić wspólnego stanowiska ze względu na rychłą śmierć najpierw Janusza ks. Ostrogskiego (12/13 września), a następnie Janusza ks. Radziwiłła (6/7 listopada). I chociaż krażyły pogłoski o tym, że opozycja gotowa jest użyć siły w walce ze zwolennikami króla, to nie wydaje się jednak, żeby książę Jerzy szykował w tym czasie jakiś antyregalistyczny rokosz. Nie miał też nic wspólnego $z$ podjęta nieco później (15 listopada 1620 r.) przez Michała Piekarskiego próbą zamachu na życie Zygmunta III. Z pewnością bracia Z barascy nie szczędzili natomiast słów potępienia dla prohabsburskiej polityki dworu. Ostro też występowali przeciwko porządkom panującym na pograniczu południowo-wschodnim i zbyt ugodowej - ich zdaniem - postawy króla i hetmana wobec ukraińskiej Kozaczyzny ${ }^{20}$.

${ }^{20}$ Por. J. Wolff, op. cit., s. 618; M. Nagielski, Sieniawski Adam Hieronim, [w:] PSB, t. XXXVII, Warszawa-Kraków 1996-1997, s. 100-102; Urzędnicy centralni..., nr 589; W. Dobrowolska, Ksiażęta..., s. 46-53; Zjazd szlachty województwa krakowskiego na rokach ziemskich $w$ Krakowie 6 stycznia 1620 r., 
W obliczu narastajacego napięcia w stosunkach $z$ Turcja Zbarascy radzili zrobić wszystko, aby nie dopuścić do wybuchu wojny. Poglady obu braci znalazły odzwierciedlenie w liście napisanym przez Krzysztofa w kwietniu 1620 r. do prymasa Wawrzyńca Gembickiego. Książę koniuszy informował arcybiskupa gnieźnieńskiego, że 16 marca w granice Rzeczypospolitej wpadło tysiąc Tatarów. „Wielki strach i szkodę niemała uczynili, a najbardziej ta calamitas padła na ostatek prawie zepsowanych majętności moich, gdzie mi wzięli do pięciuset poddanych i sług kilku dobrych, zaraz się nie bawiąc poszli z ziemie. [Piotr Konaszewicz - przyp. Z.A.] Sahajdaczny, hetman kozacki poszedł ich przejmujac w pola i tam ich rozgromił, pobił, jako WMMP z listu zrozumiesz, daj Boże by tak było". Zbaraski prosił przy tej okazji prymasa, aby swoim autorytetem wpłynał na króla i hetmana Żółkiewskiego, żeby ci swoim postępowaniem nie prowokowali Turków i dotrzymali wszystkiego, „co w paktach postanowiono, a najbardziej Kozaki, koło których bardzo niepilno chodza. Snadź się na morze gotują, a jako drudzy rozumieja, żeby i niektórzy mieli wyniść. Jakoż i ci posłowie kozaccy powiedali, co tu byli, że im pieniędzy nie dają ani sukien, oni też muszą o sobie myśleć. Tym by się pewnie strzeż Boże i Skinderbaszyne udanie i jego gniew zaczęty popędził. Niech sobie tych kilkunastu albo i więcej tysięcy, któreśmy przeszłego sejmu dali tak nie ważą, żeby dla nich i Rzeczpospolita i zdrowie swoje mieli ważyć. Więc za ta porażka teraźniejsza, mogłoby się skupieniem wojska wczesnego, rumorem samym, a tym strachem powściagnać inkursję. Bo iż to pogaństwo omina przed się często bierze i w tym roku źle sobie obiecuja, ażeby od tej teraźniejszej porażki mogli sobie jaką opinię utworzyć i nie tak się aperte ważyć. O te Kozaki znowu WMMP powtarzam, bo pewnie za tym patrzac na rzeczy, zgubę Rzeczypospolitej widzę"21.

[w:] ASWK, s. 408-422; U. Augustyniak, W. Sokołowski, Wstęp, [w:] „Spisek orleański" z lat 1626-1628, oprac. U. Augustyniak, W. Sokołowski, Warszawa 1990, s. 12-13; T. Wasilewski, Radziwiłt Janusz, [w:] PSB, t. XXX, Wrocław 1987, s. 207; A. Filipczak-Kocur, Contra...., s. 266; J. Pietrzak, Piekarski Michat, [w:] PSB, t. XXVI, Wrocław 1981, s. 73-74; Z. Oss oliński, op. cit., s. 118-120; M. Dzied u szy cki, Krótki rys dziejów i spraw Lisowczyków, t. I-II, Lwów 1843-1844; F. Kudelka, Bitwa pod Humiennem, „Przegląd Powszechny” 1902, t. LXXXV, s. 187-199; A. Szelagowski, Śląsk i Polska wobec powstania czeskiego (Sprawa północna w wiekach XVI $i$ XVII, cz. 2), Lwów 1904, s. 101, 112-118, 121-124, 144 i n.; Z. Anusik, Kasztelan..., s. 68-69.

${ }^{21}$ Por. K. Zbaraski do Wawrzyńca Gembickiego, Solec 5 IV 1620, Korespondencja..., s. 93-94. Ten sam list por. Z. Anusik, Cztery listy..., s. 473-475; oraz idem, $Z$ korespondencji księcia Krzysztofa Zbaraskiego $z$ arcybiskupem 
Niefortunna wyprawa do Mołdawii, klęska cecorska i śmierć hetmana Żółkiewskiego po rozbiciu przez Tatarów polskiego taboru pod Mohylewem (6 października 1620 r.) znowu ściagnęły gromy potępienia na politykę królewską. Dobra okazją do wytoczenia zarzutów pod adresem Zygmunta III i zmarłego hetmana stał się sejm, który obradował w Warszawie od 3 listopada do 11 grudnia 1620 r. I znowu bracia Zbarascy, cieszacy się wielkim autorytetem wśród szlachty, stanęli na czele antykrólewskiej opozycji. Pod wpływem ostrych wystąpień poselskich dwór musiał się tłumaczyć zarówno $z$ wyprawy mołdawskiej Żółkiewskiego, jak i z wysłania lisowczyków do Siedmiogrodu. $Z$ inspiracji Zbaraskich podniesiono także po raz kolejny sprawę wakansów (śmierć Żółkiewskiego sprawiła bowiem, że należało pomyśleć o obsadzeniu dwóch najważniejszych ministerstw - hetmaństwa wielkiego i kanclerstwa wielkiego koronnego). Pierwszym kandydatem do buławy wielkiej koronnej był Krzysztof ks. Zbaraski. Ponieważ jednak król nie chciał mu dać dowództwa nad wojskiem (a nie chciał też zrażać innych kandydatów do buławy), skorzystał $z$ tego, że hetman polny koronny Stanisław Koniecpolski przebywał w niewoli tureckiej (a był on przecież także poważnym kandydatem do buławy wielkiej) i przeforsował uchwałę sejmu o tymczasowym powierzeniu dowództwa nad wojskiem koronnym hetmanowi wielkiemu litewskiemu Janowi Karolowi Chodkiewiczowi, a buławy polnej - Stanisławowi Lubomirskiemu (do czasu powrotu Koniecpolskiego $z$ niewoli). Ponieważ już przed rozpoczęciem obrad sejmu król nadał Jerzemu ks. Zbaraskiemu kasztelanię krakowska, wakująca po śmierci Janusza ks. Ostrogskiego („a, że jeszcze nie zasiadł [w senacie - przyp. Z.A.] ta przyczyna, że tę funkcję [poselska - przyp. Z.A.] od braciej, na się włożoną odprawuje"), nie rozpatrywano jego kandydatury do kanclerstwa. Ostatecznie kanclerzem wielkim koronnym został podkanclerzy Andrzej Lipski, a podkanclerstwo po nim otrzymał Wacław Leszczyński. Marszałkostwo nadworne (starał się o nie także Jerzy Zbaraski za pośrednictwem Jakuba Zadzika) przypadło w udziale kasztelanowi poznańskiemu Łukaszowi Opalińskiemu. Marszałek izby poselskiej Jakub Szczawiński otrzymał województwo brzeskokujawskie, kasztelan halicki Stanisław Wołucki podkomorstwo koronne, a Stanisław Lubomirski bogate starostwo białocerkiewskie. Jedynie Krzysztof ks. Zbaraski nie otrzymał żadnej godności. Książę Jerzy natomiast

gnieźnieńskim Wawrzyñcem Gembickim, [w:] idem, Studia i szkice staropolskie, Łódź 2011, s. 75-77. 
tuż po zakończeniu obrad sejmowych (12 grudnia 1620 r.) przyjął urząd kasztelana krakowskiego. Zrobił to $z$ pewnościa niezbyt chętnie, gdyż nominacja królewska definitywnie zamknęła mu drogę do upragnionego kanclerstwa wielkiego koronnego ${ }^{22}$.

Po rozdaniu wakansów przez króla bracia Zbarascy nie zmienili bynajmniej swojego krytycznego stanowiska wobec projektów partii dworskiej. W sumie jednak na sejmie 1620 r. odegrali pożyteczna i bardzo konstruktywną rolę. Obaj weszli do komisji senatorsko-poselskiej, której zadaniem było opracowanie planu obrony przed Turcją. Trzeba też przyznać, że cały plan wojny tureckiej, który doprowadził do zwycięstwa chocimskiego, był w dużej mierze dziełem Jerzego (powołanego do Rady Wojennej przy królu) i Krzysztofa Zbaraskich. Książęta zrobili też wszystko, aby izba uchwaliła podatki niezbędne do wystawienia odpowiednio silnej armii. I chociaż ostatecznie posłowie krakowscy doprowadzili do odesłania decyzji podatkowych na sejmik relacyjny (a za ich przykładem poszło wiele innych województw), to jednak sejmik w Proszowicach (nie bez wpływu Jerzego ks. Zbaraskiego) uchwalił deklarowane na sejmie podatki. W czasie obrad sejmowych Zbarascy starli się także $z$ episkopatem, żądając od duchowieństwa nadzwyczajnego subsydium na obronę państwa. Dostało się również senatorom świeckim i duchownym, których zmuszono do złożenia deklaracji o wystawieniu prywatnych pocztów na wojnę turecka. W sprawie prowadzenia wojny $z$ Turcja przeszły na tym sejmie niemal wszystkie żądania Zbaraskich. Dodano więc hetmanom cywilnych komisarzy, „aby wojska gdzie indziej nie dawano, ani wojny przenoszono, jako postapiono $z$ lisowczykami, którzy się tym szczycili, że od KJM na posługę Rzeczypospolitej zaciagnieni byli, a przecie potym mówiono, że KJM o tym nie wiedział". Kiedy zaś okazało się, że przedstawione przez Zbaraskich plany wojny ofensywnej przeciwko Turcji nie maja najmniejszych szans powodzenia (ze względu na zbyt

22 Por. F. Suwara, Przyczyny i skutki klęski cecorskiej 1620 r., Kraków 1930; R. Majewski, Cecora rok 1620, Warszawa 1970; L. Podhorodecki, Stanisław Koniecpolski ok. 1592-1646, Warszawa 1978, s. 65-98; Z. O s soliński, op. cit., s. 125-128, 134-136; A. Filipczak-Kocur, Contra..., s. 268; W. Dobrowolska, Ksiażęta..., s. 54-60; J. Pietrzak, Po Cecorze i podczas wojny chocimskiej. Sejmy z lat 1620 i 1621, Wrocław 1983; Z. Traw i cka, Jakub Sobieski 1591-1646. Studium $z$ dziejów warstwy magnackiej w Polsce doby Wazów, Kraków 2007, s. 95-96, 107; Z. Anusik, Kasztelan..., s. 69-70; J. Dorobisz, op. cit., s. 77; E. Opaliński, op. cit., s. 250; J. Wolff, op. cit., s. 618; W. Konopczyński, op. cit., s. 21 (147). 
wielką skalę tego przedsięwzięcia), książę Krzysztof wystąpił z żądaniem, aby zaciagnąc jedynie 31 tys. żołnierzy, bo tylko tyle można było wystawić $z$ podatków uchwalonych przez sejm. Ponadto książęta przestrzegali sejmujące stany, żeby nie przyjmować do służby więcej wojska, niż pozwalaja na to posiadane fundusze, gdyż nieopłacony żołnierz w przeszłości wielokrotnie zniweczył dokonania najlepiej nawet prowadzonych kampanii. Ostatecznie też niemal wszystkie żądania Zbaraskich znalazły się w contentach marszałka sejmowego i zostały przez sejm uchwalone. Warte odnotowania wydaje się również to, że mimo zgody większości posłów na skrócenie obrad, Zbarascy do tego nie dopuścili i sejm trwał ustawowe sześć tygodni (książęta żądali rozpatrzenia przez króla sformułowanych przez nich na początku obrad egzorbitancji, czyli „urazów prawa”). Po zakończeniu sejmu obaj Zbarascy wnieśli do grodu krakowskiego (21 lutego 1621 r.) protest Przeciwko niektórym wariacjom konstytucji na sejmie namówionych $i$ sensu wyraźnego ad mentem na ten czas tak koła poselskiego, jako i z pozwolenia JKM $z$ senatem. Chodziło tu o bezprawne - ich zdaniem - zmiany w tekście 8 konstytucji sejmowych dokonane między zakończeniem obrad a podaniem uchwał sejmowych do druku ${ }^{23}$.

Jako kasztelan krakowski, pierwszy świecki senator Rzeczypospolitej, Jerzy ks. Zbaraski poczuwał się do obowiazku doradzania królowi i recenzowania niemal wszystkich decyzji politycznych

${ }^{23}$ Więcej na temat poczynań Zbaraskich podczas obrad tego sejmu por. W. Dobrowolska, Książęta..., s. 60-63; J. Pietrzak, Po Cecorze..., s. 64-65, 80, 82-85, 101 i n.; A. Filipczak-Kocur, op. cit., s. 267-268; Z. Trawicka, op. cit., s. 96-97; Konstytucye seymu walnego koronnego warszawskiego R.P. 1620, [w:] Vol. leg., t. III, s. 176-198; Sejmik posejmowy województwa krakowskiego w Proszowicach 30-31 grudnia 1620 r., [w:] ASWK, s. 423-426. Dodajmy, że przedstawiony przez Zbaraskich na sejmie 1620 r. plan wojny tureckiej przewidywał utworzenie trzech wielkich armii. Pierwsza $z$ nich, licząca 60 tys. zaciężnych żołnierzy, miała wkroczyć do Mołdawii i obsadzić linię Dunaju tak, aby zmusić Turków do podjęcia walki na ich terytorium. Druga armia miała się składać z pospolitego ruszenia i stanowić rezerwę dla wojsk zaciężnych. Trzecią armię, liczaca aż 80 tys. ludzi, mieli utworzyć Kozacy Zaporoscy. Mieli oni wyprawić się na czajkach na Morze Czarne i zaatakować Stambuł. Nie trzeba jednak dodawać, że był to projekt zdecydowanie przekraczajacy możliwości finansowe państwa polsko-litewskiego i właśnie $z$ tego powodu nigdy nie został zrealizowany. Por. P. G aw ro n, Projekty reform armii Rzeczypospolitej w latach 20. XVII w. na tle wojskowości zachodnioeuropejskiej, [w:] Staropolski ogląd świata. Rzeczpospolita między okcydentalizmem a orientalizacja, t. I (Przestrzeń kontaktów), red. F. Wolański, R. Kołodziej, Toruń 2009, s. 188-189; J. Pietrzak, Po Cecorze..., s. 62 i n.; Z. Anusik, Kasztelan..., s. 70-72. 
podejmowanych na dworze. Objęcie urzędu senatorskiego nie wpłynęło jednak w żaden sposób ani na poglądy, ani postawę księcia Jerzego. Przez cały czas pozostawał on zdeklarowanym opozycjonistą wobec rządów Zygmunta III i prawie zawsze występował przeciwko kolejnym inicjatywom politycznym monarchy. W poczatkach lutego 1621 r. pan krakowski wyrażał swój niepokój z powodu opieszałych przygotowań do wojny przeciwko Turcji. Domagał się od króla szybkiego uzgodnienia warunków, na jakich Jan Karol Chodkiewicz miał objąć dowództwo nad armią koronną. Popierał zresztą w tym względzie stanowisko wojewody wileńskiego. Przestrzegał też władcę przed zaciaganiem do wojska Rzeczypospolitej lisowczyków, którzy w początkach 1621 r. na wezwanie króla powrócili do kraju ze służby cesarskiej. Zwracał uwagę na ich niekarność, skłonność do łupiestwa i niewielką wartość bojową ${ }^{24}$. W kilka tygodni później namawiał monarchę do wysłania gońca do Stambułu i podjęcia rozmów pokojowych $z$ Turkami. Jego zdaniem swojego posła do wezyra mógłby wysłać również hetman Chodkiewicz. Swoje stanowisko uzasadniał Zbaraski słabościa przygotowań wojennych Rzeczypospolitej. $Z$ tego też powodu zachęcał króla do szybkiego działania, aby rozmowy $z$ Turkami zostały rozpoczęte, zanim sułtan wyjedzie ze swojej stolicy, „gdyż on, który barbaro fastu tak jest nadęty, że po Bogu pierwszy majestatem swoję kładzie, rozumiałby inferius być sua Majestate wrócić się nazad, albo non confecto bello, albo superbissimis conditionibus nie dawszy pokoju". Przy tej samej okazji książę Jerzy, który wojnę uważał za ostateczność i ostrzegał przed nią Zygmunta III, podjął również w charakterystyczny dla siebie sposób kwestię kozacką. Obawiał się bowiem, żeby Kozacy przez swoje poczynania nie zniweczyli zabiegów o utrzymanie pokoju $z$ Turcją. Dlatego też prosił króla, aby „zaraz raczył rozkazać panu wojewodzie wileńskiemu, aby surowe uniwersały do nich rozesłał, aby szli nad Dniepr co prędzej i tatarskiej przeprawy

${ }^{24}$ Jerzy Zbaraski do Zygmunta III, Kraków 16 i 26 II 1621, Listy księcia Jerzego Zbaraskiego kasztelana krakowskiego z lat 1621-1631, wyd. A. Sokołowski, Scriptores Rerum Polonicarum, t. V, Kraków 1880, s. 22-23, 24-25. Por. też L. Pod horodecki, Jan Karol Chodkiewicz 1560-1621, Warszawa 1982, s. 299-304 (tu jednak na s. 302 pozbawione podstaw twierdzenie, że Jerzy ks. Zbaraski postulował odebranie naczelnego dowództwa Chodkiewiczowi i przekazanie go własnemu bratu); H. Kotars ki, Kalinowski Idzi, [w:] PSB, t. XI, Wrocław-Warszawa-Kraków 1964-1965, s. 454-455; A. Filipczak-Kocur, Contra..., s. 268-269; Z. Anusik, Kasztelan..., s. 72-74. 
strzegli, a skoro da znać, żeby szli na morze infestować Turka, bo inaczej ich nie zahamuje pewnie" 25 .

W czerwcu 1621 r. kasztelan krakowski wskazywał na poważne zagrożenie Małopolski w przypadku, gdyby Turcy zdecydowali się uderzyć $z$ dwóch stron na Rzeczpospolitą. Obawiał się, że sułtan może wysłać 200 tys. ludzi na Kamieniec, a sam $z$ inną armią spod Belgradu może pójść na Eger i Koszyce, „a z Koszyc do Krakowa 26 mil drogami dobremi i przestronnemi, i kto by mu impediet, radbym to wiedział". Zdaniem Zbaraskiego, gdyby 10 tys. Tatarów znalazło się pod murami stolicy, zapaliwszy Kleparz i inne przedmieścia, „dymem i płomieniami wydusiliby Kraków wszystek”. Książę pisał także, że nawet w przypadku, gdyby sułtan poszedł $z$ główną armia na Podole, to wystarczyłby atak ze strony władcy Siedmiogrodu lub jakiegoś pogranicznego paszy, aby Kraków dostał się w ręce Turków, „bo ani bronić, ani obronić [stolicy] nie masz podobieństwa żadnego" 26 .

W początkach lipca 1621 r. Jerzy ks. Zbaraski skarżył się na postępowanie ówczesnego hetmana Kozaków Zaporoskich Jacka Borodawki oraz wysłanego na Zaporoże sekretarza królewskiego Bartłomieja Obałkowskiego. W liście do Zygmunta III pisał, że Borodawka posłał uniwersał do wszystkich dóbr królewskich i szlacheckich na Ukrainie, „gdzie ja też mam $z$ bratem moim szmat majętności moich, rozkazując sobie chować konie pod armatę, prochy, ołów i do każdego miasteczka regestr posłali, jako wiele czego skąd potrzebują". A wszystko to za wiedza, zgodą i namową Obałkowskiego, który „tą kondycją ich z Zaporoża wywiódł, że im pozwolił tak w dobrach WKM, jak i szlacheckich to, com wzwyż mianował brać pro libitu". Zbaraski był oburzony tymi działaniami i zapowiedział wszczęcie kroków prawnych przeciwko Obałkowskiemu, „gdyż i tak krzywd od żołnierzów i od tego inszego hultajstwa, które się włóczy, aż nazbyt

25 J. Zbaraski do Zygmunta III, Kraków 29 V 1621, Listy..., s. 28-30. Por. też L. Podh orodecki, Jan Karol...., s. 303-305 (tu o trudnościach $z$ wystawieniem przez Rzeczpospolita armii na wojnę turecka i zabiegach o pozyskanie Kozaczyzny Zaporoskiej).

${ }^{26}$ J. Zbaraski do Zygmunta III, Kraków 12 VI 1621, Listy..., s. 30-33. Warto w tym miejscu zwrócić uwage na to, że opracowany przez dowództwo tureckie pierwotny plan wojny z Polską rzeczywiście przewidywał uderzenie na Rzeczpospolita $z$ dwóch kierunków - z Mołdawii na Lwów i z Siedmiogrodu na Kraków. Na Lwów miał wyruszyć sam sułtan z głównymi siłami, a na Kraków Bethlen Gabor z Siedmiogrodzianami oraz posiłkami tureckimi i tatarskimi. Por. L. Podhorodecki, Jan Karol..., s. 311. 
mam, że prawie mi wszystko popustoszono, jeśli jeszcze i tę severitatem od tego swawoleństwa ostatnią cierpieć mam, w sercu mojem z śmiercią by mi się to równało" 27 .

Kilka dni później kasztelan krakowski w liście do króla ponownie powrócił do spraw podnoszonych we wcześniejszej korespondencji. Wyraził ogromne zdziwienie, że Zygmunt III skarży się na nieposłuszeństwo kozackie, „za którym i pan Obełkowski miałby na nie protestacyja uczynić w Kijowie. Zaprawdę validum remedium na tak uczciwe ludzie". Ostrzegał też monarchę przed uchwałami kijowskiego synodu wyznawców prawosławia, „który był w świątki między wszystkiem prawie duchowieństwem i ludźmi religii greckiej, których praesidium sa Kozacy". Niepokoiło go także to, że zaraz po synodzie odbyła się rada kozacka w Suchej Dąbrowie. Przypuszczał bowiem, „że wyleci coś stamtąd dość niepociesznego". Ponownie oburzał się także Zbaraski na zaciaganie lisowczyków do wojska koronnego. Jego poważny niepokój budziło skierowanie ich oddziałów nad granicę węgierską i rabunki dokonywane w województwach krakowskim i sandomierskim. Zdaniem kasztelana krakowskiego pojawienie się lisowczyków na granicy z Węgrami mogło mieć fatalne konsekwencje dla Rzeczypospolitej. Pogłoski o rychłym wkroczeniu Polaków miały bowiem ostatecznie przekonać stany węgierskie do porozumienia się $z$ Bethlenem Gaborem i wezwania na pomoc Turków i Tatarów ${ }^{28}$.

W poczatkach sierpnia 1621 r. Jerzy ks. Zbaraski pisał do Zygmunta III, że wysłannik stanów węgierskich oddał mu kolejny list od swoich mocodawców oraz list od władcy Siedmiogrodu. Ten ostatni zapewniał Rzeczpospolita o swojej przyjaźni i ostrzegał, że wojska tureckie i tatarskie ruszyły w kierunku jej granic. Zbaraski jednak nie wierzył w dobra wolę Bethlena Gabora i uważał go za wiernego

27 J. Zbaraski do Zygmunta III, Kraków 3 VII 1621, Listy..., s. 34; K. Tyszkowski, Borodawka Nerodowicz Jakób (Jacko), [w:] PSB, t. II, Kraków 1936, s. 342; Z. Anusik, Kasztelan..., s. 76 (tu jednak błędne stwierdzenie, że hetmanem kozackim, na którego postępowanie skarżył się pan krakowski, był Piotr Konaszewicz-Sahajdaczny).

${ }^{28}$ J. Zbaraski do Zygmunta III, Kraków 9 VII 1621, Listy..., s. 37-38. Dodajmy w tym miejscu, że zgromadzeni na uroczysku Sucha Dąbrowa Kozacy zdecydowali się udzielić Rzeczypospolitej pomocy w wojnie $z$ Turcja. Wysłali jednak poselstwo do króla, proszac go m.in. o zatwierdzenie nielegalnie wyświęconych przez patriarchę jerozolimskiego Teofanesa hierarchów cerkwi prawosławnej. Więcej informacji na ten temat por. M. Drozdowski, Religia i Kozaczyzna Zaporoska $w$ Rzeczypospolitej w pierwszej połowie XVII wieku, Warszawa 2008, s. 95-107; A. Filipczak-Kocur, Książę..., s. 44. 
lennika sułtana, a zatem wroga Rzeczypospolitej i całego chrześcijaństwa ${ }^{29}$. Dnia 4 września 1621 r. Jerzy ks. Zbaraski pojawił się w Warszawie, aby wziąć udział w sejmie ekstraordynaryjnym, który rozpoczą swoje obrady 27 sierpnia. W swoim wotum senatorskim apelował o pospolite ruszenie $z$ Korony i Litwy. Spotkało się to $z$ pełna aprobata zarówno ze strony senatorów, jak i posłów. W izbie poselskiej zasiadał brat księcia Jerzego - Krzysztof, który posłował na ten sejm $z$ województwa sandomierskiego. Zajmował on postawę krytyczną w stosunku do króla. Obu braci Zbaraskich zabrakło w obozie chocimskim. W czasie walk $z$ wojskami tureckimi Jerzy bawił bowiem w swoich dobrach w Małopolsce, a książę koniuszy z grupa innych senatorów i dygnitarzy u boku Zygmunta III. Należy jednak jeszcze raz podkreślić, że opracowanie planu zwycięskiej kampanii 1621 r. (zwłaszcza od strony organizacyjnej) było w dużej mierze dziełem i zasługa książąt Jerzego i Krzysztofa Zbaraskich ${ }^{30}$.

W dniu 30 października 1621 r. Jerzy ks. Zbaraski przesłał królowi gratulacje $z$ powodu pomyślnego zakończenia kampanii chocimskiej i zawarcia traktatu pokojowego $z$ Turkami. Jego zdaniem pakty chocimskie stanowiły wybawienie dla Rzeczypospolitej spustoszonej wojna, przejściem wojska, powodziami i jesienna niepogodą. $Z$ tego powodu wzywał Zygmunta III do jak najszybszego potwierdzenia układu zawartego pod Chocimiem i wysłania do Stambułu odpowiedniej rangi poselstwa. Książę Jerzy nalegał też, aby poseł wielki wyjechał do stolicy Turcji zaraz po Bożym Narodzeniu. „A lubo by też kilka niedziel przedłużył, przynajmniej żeby dał wezyrom i hospodarowi wołoskiemu [mołdawskiemu - przyp. Z.A.] o sobie znać, że już jest od WKM naznaczony, żeby nie byli suspensi na to i non ambigeretur u Turków pokoju". Wzywał także władcę do uspokojenia Kozaków, obmyślenia płacy dla wojska i znalezienia środków na wypłatę upominków tatarskich. Najważniejszą dla niego kwestia było jednak utrzymanie świeżo zawartego pokoju, o czym tak pisał do Zygmunta III: „Racz to ukazać wszystkim narodom i państwom, że jako to consilio et armis umiałeś tak państwa

${ }^{29}$ J. Zbaraski do Zygmunta III, Kraków 2 VIII 1621, Listy..., s. 39-40.

${ }^{30}$ Por. A. Filipczak-Kocur, Contra..., s. 270; J. Pietrzak, Po Cecorze..., s. 152 i n.; Konstytucye seymu walnego koronnego warszawskiego R.P. 1620, [w:] Vol. leg., t. III, s. 176-198; J. Tretiak, Historia wojny chocimskiej (1621), Kraków 1921; L. Podhorodecki, N. Raszba, Wojna chocimska 1621 r., Kraków 1979; L. Podhorodecki, Jan Karol..., s. 326-388; Z. Trawicka, op. cit., s. 98-102; Z. Anu sik, Cztery listy..., s. 469; id e m, Kariery..., s. 53; id e m, Kasztelan..., s. 78; W. Konopczyńs ki, op. cit., s. 21 (147). 
sobie od Pana Boga powierzone od upadku wyzwolić, tak i pokojem, dla którego się wszystkie arma, wszystkie pericula podnosza, umiesz wszystkie aerumnas nasze uleczyć"31.

Dopiero kilka miesięcy później król zdecydował się wyznaczyć posła wielkiego do Stambułu. Został nim młodszy z braci Zbaraskich - Krzysztof. Dnia 13 stycznia informował on hetmana polnego litewskiego Krzysztofa Radziwiłła, że zdecydował się odbyć „we wszystkim przykre i niebezpieczne poselstwo". Skarżył się przy tej okazji na brak w skarbie królewskim pieniędzy na upominki dla tureckich dygnitarzy. Wspomniał też o wyznaczeniu komisji do pertraktacji z Kozakami, „na czym wszystka rzecz należy”. Przewidywał, że w drogę do stolicy Turcji wyruszy nie wcześniej niż po Wielkiej Nocy $^{32}$. Tymczasem pojawiły się kolejne przeszkody. W skarbie nadal nie było pieniędzy, a Kozacy po staremu urządzali wyprawy na terytorium Turcji. W odwecie na Rzeczpospolita spadł najazd tatarski. Zygmunt III postanowił więc odwlec misję Zbaraskiego do czasu, aż sytuacja się unormuje. W początkach maja 1622 r. starszy $z$ braci Zbaraskich w liście do monarchy wyraził zaniepokojenie możliwościa wznowienia wojny tureckiej. $Z$ wielkim żalem książę Jerzy przyjął wiadomość o śmierci Piotra Konaszewicza-Sahajdacznego, którego uważał za wiernego sługe króla i Rzeczypospolitej. Obawiał się, że pozbawieni utrzymującego ich w ryzach hetmana, Kozacy znowu staną się poważnym problemem dla państwa polsko-litewskiego („Wykradło się ich snać do Dońców niemało i poszli $z$ nimi na morze"). Niepokój pana krakowskiego budziło też to, że od czasu zakończenia walk pod Chocimiem nie wysłano posła polskiego na Krym, co mogło doprowadzić do wyprawy tatarskiej na kresy południowo-wschodnie. Zażegnanie niebezpieczeństw upatrywał Zbaraski przede wszystkim w uregulowaniu stosunków z Turcja. Radził królowi, aby pisma do wezyra napisali jego brat, Krzysztof ks. Zbaraski, jako wyznaczony już poseł Rzeczypospolitej do Porty, Stanisław Lubomirski, jako wódz spod Chocimia, oraz obecni w obozie chocimskim komisarze - Mikołaj Sieniawski i Jakub Sobieski. Mieli oni ostrzec Turków o wyprawie Kozaków Dońskich (w służbie moskiewskiej) na Morze Czarne, złożyć skarge na Kantymira za najazdy ordy budziackiej na Ukrainę i przesłać tekst przysięgi na wierność królowi złożonej przez

${ }^{31}$ J. Zbaraski do Zygmunta III, Solec 30 X 1621, Listy..., s. 41-44.

${ }^{32}$ K. Zbaraski do Krzysztofa Radziwiłła, Warszawa 13 I 1622, Korespondencja..., s. 105. 
Kozaków Zaporoskich. Prosił także Zygmunta III o jak najszybsze odesłanie posła tatarskiego i wyznaczenie nowego hetmana kozackiego. Decyzję personalna w tej ostatniej sprawie radził pozostawić do uznania Bartłomieja Obałkowskiego, jako najlepiej zorientowanego w kwestiach kozackich ${ }^{33}$.

W poczatkach czerwca 1622 r. uwaga Jerzego ks. Zbaraskiego skoncentrowana była głównie na odpowiednim przygotowaniu stambulskiej legacji jego brata. $Z$ myślą o bezpieczeństwie orszaku poselskiego obserwował więc sytuację na południowo-wschodnim pograniczu i zachęcał króla do uśmierzania wszelkich ognisk zapalnych. Skarżył się na wyprawy kozackie na Morze Czarne oraz na poczynania starosty bracławskiego Adama Kalinowskiego, którego ludzie mieli organizować wypady aż pod Białogród przeciwko Tatarom, którym zagarnęli stada koni, oraz do Mołdawii, gdzie złupili jakiś monastyr ${ }^{34}$. W tym samym czasie książę Krzysztof pisał do Kozaków Zaporoskich, przypominając im o złożeniu na ręce króla zapewnienia, że nie będa organizować wypraw na Morze Czarne. Mimo to „siła ludzi kozackich” udała się nad Don, a inni zorganizowali wyprawę na morze. Tych, co poszli nad Don, uznano za zdrajców, którzy porzucili ojczyznę i przeszli na służbę cara. Uczestnicy wyprawy na Morze Czarne zdobyli jednak na Turkach bogate łupy i powrócili na Niż. Książę koniuszy żądał więc ukarania „swawolników" i wydania hersztów komisarzom królewskim. Chciał także, aby zbiegłych nad Don Kozaków wytrabiono $z$ wojska zaporoskiego i skonfiskowano im wszelką własność ${ }^{35}$.

W pisanym kilkanaście dni później liście do króla książę koniuszy szerzej zajął się kwestią kozacką. Przypominał, że dawno już radził powstrzymać Kozaków. Przyczynę ich kolejnych wypraw na morze widział w braku wypłaty obiecanych Zaporożcom pieniędzy. Zmarły hetman Konaszewicz-Sahajdaczny chciał powstrzymać nieposłusznych, ale bezskutecznie. Poza tym Zbaraski uważał, że zbyt późno odprawiono posła tatarskiego, co mogło grozić zemstą ze strony chana. Pisał, że to właśnie od Kozaków zależy, czy z Turkami będzie pokój czy wojna. Wskazywał dwa sposoby powstrzymania

${ }^{33}$ J. Zbaraski do Zygmunta III, Kraków 8 V 1622, Listy..., s. 54-55. Por. też W. Majewski, Konaszewicz (Kunaszewicz) Sahajdaczny Piotr, [w:] PSB, t. XIII, s. 484-486 (hetman zmarł 22 IV 1622 r. w Kijowie); oraz Z. Anu sik, Kasztelan..., s. $81-82$.

${ }^{34}$ J. Zbaraski do Zygmunta III, Kraków 8 VI 1622, Listy..., s. 56-57.

${ }^{35}$ K. Zbaraski do mołojców, 4 VI 1622, Korespondencja..., s. 109-110. 
Zaporożców. Pierwszym miało być wypłacenie obiecanych im 50 tys. złotych. Twierdził, że jeśli Kozacy nie dostana pieniędzy, to pójda na Niż i na morze. Gdyby zaś chcieli ruszyć na włości ukrainne, byliby szkodliwsi od nieprzyjaciela, „nie dla drapiestwa jakiego, bo to mniejsza, ale dla różnych złych zamysłów, które ich popi in pectora agunt'. Nie bez przyczyny wybrali bowiem hetmana sprzyjającego dyzunitom (został nim Olifer Hołub). Na Ukrainie przyłączą się do nich różne niespokojne duchy, w tym uczestnicy żołnierskiej konfederacji. „Czując się w sile swojej, by zaś nie chcieli do czego się inszego piąć". Książę koniuszy twierdził, że z całą stanowczością należy zwalczać pogłoski o możliwości wybuchu wojny z Turcją. Kozaków zaś, „dawszy im pieniądze, zaciagnąc ich albo do Moskwy... albo na bardzo ciężkie imprezy i niebezpieczeństwa”. Rozwiąanie problemu widział w wysłaniu Zaporożców do Inflant na wojnę ze Szwedami. Ponieważ zaś przypuszczał, że to rozwiązanie nie zostanie przez Zygmunta III zaakceptowane, powtórzył swoją prośbę o bezzwłoczne przesłanie pieniędzy do Kijowa i wypłacenie Kozakom wszystkich należności ${ }^{36}$.

Dopiero 6 sierpnia 1622 r. Krzysztof ks. Zbaraski odebrał w Warszawie instrukcje dotyczące jego poselstwa. Kilka dni później pan krakowski otrzymał $z$ dworu królewskiego niepokojące wieści, że w związu $z$ zamachem stanu w Stambule i zamordowaniem sułtana Osmana II pieniądze na upominki dla dygnitarzy tureckich (obiecane im $\mathrm{w}$ traktacie chocimskim) zostały przeznaczone przez Zygmunta III na zaspokojenie pretensji finansowych wojska, które po wojnie tureckiej, nie otrzymawszy należnej zapłaty, zawiąało konfederację lwowską. Zbaraski przekonywał króla, że popełnia on poważny błąd polityczny, gdyż bez pieniędzy na upominki jego brat nie będzie mógł odbyć legacji. Następcy zamordowanych $z$ sułtanem urzędników $z$ pewnością bowiem upomna się o podarki obiecane ich poprzednikom, co oznacza, że książę koniuszy albo niczego nie mógłby „sprawić, albo w zakładzie być tam długo dla tych kilkudziesiąt tysięcy talarów, ażby je odesłano". Jednocześnie książę Jerzy zaręczał, że jego brat sumiennie rozliczy się $z$ otrzymanych pieniędzy, nie będzie nimi szastał i jeśli nie zostanie zmuszony przez okoliczności, nie wręczy upominków nowym dygnitarzom dworu sułtańskiego, „tylko odda je tam, gdzie je weźmie”37. Do sprawy tej

${ }^{36}$ K. Zbaraski do Zygmunta III, 16 VI 1622, Korespondencja..., s. 110-112.

${ }^{37}$ J. Zbaraski do Zygmunta III, Pilica 13 VIII 1622, Listy..., s. 58-59. Por. też A. Filipczak-Kocu r, Książę..., s. 25-26; oraz Z. Anu sik, Kasztelan..., s. 82-83. 
powrócił kasztelan krakowski w kolejnym liście do króla. Dziękował za przyznanie księciu koniuszemu sumy 20 tys. talarów na upominki tureckie. Ponieważ jednak suma ta wydawała mu się zbyt mała w stosunku do obietnic poczynionych Turkom pod Chocimiem, prosił dodatkowo o podpisanie przez władcę pisma wyrażającego zgodę na zadłużenie się księcia Krzysztofa u kupców stambulskich w przypadku, gdyby wymagał tego interes Rzeczypospolitej ${ }^{38}$.

We wrześniu 1622 r., odpowiadając monarsze na zapytanie o materię obrad przyszłego sejmu, pan krakowski ponownie odniósł się do kwestii kozackiej. „Więc Kozacy zaporoscy, aby mieli być coerciti sine armis, to jest rzecz niepodobna". Żadne traktaty nie utrzymają ich w posłuszeństwie, gdyż jest to "gens insolens, nadęta tą wojną teraźniejszą z Turki tak tumida, że lekko sobie wszystkie imperata waży". O Kozakach miał zresztą książę jak najgorsze zdanie i twierdził, że „póki krwią się nie ustraszą swą, niepodobna rzecz, aby mieli obsequi, bo nihil modicum in vulgo"39. W październiku 1622 r. Jerzy ks. Zbaraski schronił się przed zaraza w Solcu nad Wisłą, w starostwie należącym do jego brata. Pisał stąd do wojewody sandomierskiego Zbigniewa Ossolińskiego (popierającego braci Zbaraskich w czasie ich konfliktu $z$ hetmanem Żółkiewskim), starając się uzgodnić $z$ nim stanowisko, jakie należałoby zająć na zbliżającym się sejmie. W liście tym książę Jerzy wspomniał także o konieczności poskromienia Kozaków, na czym „wszystka anima pokoju $z$ Turki zawisła”. Radził użycie najsurowszych środków i krwawe przywrócenie Zaporożców do posłuszeństwa ${ }^{40}$.

W lutym 1623 r. Jerzy ks. Zbaraski zjawił się na sejmie walnym w Warszawie obradującym od 24 stycznia do 5 marca. Spóźnił się co prawda na inauguracje obrad, ale zdażył jeszcze wygłosić swoje wotum. Poruszył w nim problemy, które od dłuższego czasu pojawiały się $\mathrm{w}$ jego korespondencji z Zygmuntem III. Zdecydowanie i w ostrych słowach wystapił przeciwko konfederacjom żołnierskim, oskarżając ich twórców i uczestników o grabienie własnego kraju i wysuwanie wygórowanych żądań finansowych. W swoim wystąpieniu książę kasztelan poruszył także problem swawoli kozackiej, obawiając się zadrażnienia stosunków z Turcją. Proponował

38 J. Zbaraski do Zygmunta III, Pilica 9 IX 1622, Listy..., s. 59-60. Więcej na temat wspomnianej tutaj konfederacji wojskowej por. J. Pietrzak, Konfederacja lwowska w 1622 roku, „Kwartalnik Historyczny” 1973, R. LXXX, z. 4, s. 845-871.

${ }^{39}$ J. Zbaraski do Zygmunta III, Pilica 18 IX 1622, Listy..., s. 60-61.

${ }^{40}$ J. Zbaraski do Zbigniewa Ossolińskiego, Solec 15 X 1622, Listy..., s. 62-65. 
szybkie wysłanie listów od króla, senatu i sejmu z zapewnieniem, że jeśli Zaporożcy nie wyjda na morze, Rzeczpospolita dotrzyma paktów i będzie płaciła im żołd. Sugerował jednak, aby równocześnie zgromadzić jak najwięcej wojska na Ukrainie i strachem zmusić Kozaków do uległości ${ }^{41}$.

Wkrótce po zakończeniu obrad sejmu 1623 r. (w niedzielę wielkanocna, czyli 16 kwietnia był on już w Końskowoli) wrócił z Turcji brat księcia Jerzego. Poselstwo Krzysztofa ks. Zbaraskiego przyniosło Rzeczypospolitej realne korzyści pod każdym względem, gdyż poseł odprawił swoją legację nie tylko wspaniale, lecz także bardzo zręcznie. Udało mu się bowiem przekonać wezyra Husseina o potrzebie utrzymania trwałego pokoju między Porta a Polska i uzyskać potwierdzenie traktatu chocimskiego. Ponadto Zbaraski doprowadził do uwolnienia wziętych do niewoli po klęsce cecorskiej jeńców polskich (część $z$ nich wykupił za własne pieniądze). Ambicje braci Zbaraskich zostały więc zaspokojone, aczkolwiek ponieśli oni przy tej okazji dość znaczne wydatki ${ }^{42}$.

${ }^{41}$ Mowa ks. Jerzego Zbaraskiego na sejmie walnym, który był w Warszawie roku 1623, Listy..., s. 71-79; A. Filipczak-Kocur, Contra..., s. 272; J. Pietrzak, W przygaszonym blasku wiktorii chocimskiej. Sejm z 1623 roku, Wrocław 1987, s. 68 i n., 77-78, 82-84; Z. Trawicka, op. cit., s. 113-117; W. Konopczyńs ki, op. cit., s. 21 (147).

${ }^{42}$ Krzysztof ks. Zbaraski wyruszył do Stambułu w początkach września $1622 \mathrm{r}$. na czele orszaku liczacego ponad 1000 osób. W końcu listopada odbył uroczysty wjazd do stolicy Turcji, a 6 XII został przyjęty na audiencji przez sułtana. Początkowo rokowania toczyły się w napiętej atmosferze, gdyż Turcy usiłowali zastraszyć Zbaraskiego groźbą wznowienia wojny. Żąali też haraczu od Rzeczypospolitej. Książę Krzysztof nie poszedł jednak na żadne ustępstwa i doczekał chwili, kiedy w styczniu 1623 r. janczarzy obalili dotychczasowego wezyra i wynieśli na ten urząd przychylnego Polsce Husseina paszę. Z nim właśnie Zbaraski wynegocjował porozumienie ze wszech miar korzystne dla państwa polsko-litewskiego. I chociaż przywieziony przez księcia-koniuszego do Polski turecki tekst zawartego w Stambule traktatu odbiegał w kilku punktach od treści paktów chocimskich (w celu naniesienia poprawek o charakterze formalnym - istotnych jednak ze względu na prestiż króla i Rzeczypospolitej - wysłano do Turcji orientalistę Krzysztofa Serebkowica), to nie ma to najmniejszego nawet wpływu na ocene jego poselstwa. Najważniejszym rezultatem legacji Krzysztofa ks. Zbaraskiego było bowiem przekonanie Turków o konieczności utrzymania pokoju z Rzecząpospolitą i respektowania w całej rozciagłości traktatu chocimskiego (dodajmy tu tylko, że o wprowadzonych dzięki zabiegom Serebkowica zmianach w tekście porozumienia z Polska - po przekupieniu pisarzy z kancelarii - wezyr Hussein nie został nawet poinformowany). Por. Przeważna legacja Krzysztofa Zbaraskiego, koniuszego wielkiego koronnego, do Turcji w r. 1622, [w:] Dyplomaci w dawnych czasach. Relacje staropolskie z XVI-XVIII stulecia, oprac. A. Przyboś i R. Żelewski, Kraków 1959, s. 196-206; 
Wkrótce po swoim powrocie ze Stambułu Krzysztof ks. Zbaraski napisał list do arcybiskupa gnieźnieńskiego Wawrzyńca Gembickiego. Przekazał mu szereg informacji dotyczacych sytuacji na południowym i południowo-wschodnim pograniczu Rzeczypospolitej. Pisał o kolejnych wyprawach kozackich na Morze Czarne i ostrzegał przed odwetowym najazdem tatarskim. Odniósł się także do powołanej na sejmie komisji, która miała doprowadzić do zawarcia jakiegoś porozumienia $z$ Kozaczyzna Zaporoska.. „Kozacka komisja następuje, z której wszyscy się snadź co zacniejsi wymówieli. Nie zostaje rozumiem podkomorzy kijowski [Stefan Niemirycz - przyp. Z.A.], a mój pan [Jan - przyp. Z.A] Bielecki, co za fundus i authoritas przy nich, to WMMP racz considerować. Rozkazali do wielkiej rady gotować każdemu po kilku funtach prochu i kul po kilku kop. Ba i toć napiszę, że tak concorditer mówią, król do Szwecyjej pojechał, Lachowie nam nic nie uczynia, obierzem sobie swego. Za pewne mi też i to dano znać i ten, co go w Wołoszech widzial, że aleksandryjski jakiś patriarcha ku nim pojechał i to sine motu nie będzie"43.

Jesienią 1623 r. Jerzy ks. Zbaraski w listach do króla poruszal przede wszystkim problem lisowczyków, którzy wrócili do kraju po odprawieniu ich ze służby cesarskiej. Doradzał aresztowanie i osadzenie ich hetmana Lanikowskiego ${ }^{44}$. Kiedy zaś w listopadzie agent cesarza Ferdynanda II, Adolf hr. Altheim ponownie przystapił do werbowania elearów do służby cesarskiej, kasztelan krakowski naciskał na Zygmunta III, aby zabronił tych zaciagów, gdyż uwa$\dot{z ̇ a ł}, \dot{z}$ e może to grozić wznowieniem wojny tureckiej ${ }^{45}$. Zbaraski nie posiadał się też $z$ oburzenia, kiedy otrzymał list królewski $z$ rozkazem, aby w porozumieniu $z$ innymi panami małopolskimi na własna rękę zaczął walczyć $z$ lisowczykami. Irytował go to, że król zasłania się niedostatkiem własnego skarbu i bez ogródek sięga do kieszeni

J. Wojtasik, Uwagi księcia Krzysztofa Zbaraskiego, posła wielkiego do Turcji z 1622 roku - O państwie ottomańskim i jego siłach zbrojnych, „Studia i Materiały do Historii Wojskowości" 1961, t. VII, cz. 1, s. 321-346; H. W is n e r, Dyplomacja polska w latach 1572-1648, [w:] Historia dyplomacji polskiej, t. II (1572-1795), red. Z. Wójcik, Warszawa 1982, s. 81-82 (tu chybiona w sumie próba zdyskredytowania osiągnięć poselstwa Zbaraskiego w Stambule); W. Dobrow ols ka, Ksiażęta..., s. 64-65; A. Filipczak-Kocur, Książe..., s. 27-32; Z. Anusik, Cztery listy..., s. 470 (tu wykaz najważniejszych źródeł i literatury przedmiotu).

${ }^{43}$ K. Zbaraski do W. Gembickiego, Końskowola 23 V 1623, Korespondencja..., s. 124-127; ten sam list por. Z. Anusik, Cztery listy..., s. 478-479; oraz id e m, $Z$ korespondencji..., s. 79-84.

${ }^{44}$ J. Zbaraski do Zygmunta III, Pilica 30 IX 1623, Listy..., s. 79-80.

${ }^{45}$ J. Zbaraski do Zygmunta III, Pilica 20 XI 1623, Listy..., s. 80-81. 
tych, których dobra najwięcej ucierpiały od niepłatnego żołnierza. Odmawiając wykonania poleceń królewskich, książę Jerzy zaznaczył przy tym, że jest przekonany, iż wysłannicy królewscy do lisowczyków co innego publicznie, a co innego sekretnie im rozkazuja. Wyciagał stąd uzasadniony wniosek, że zaciagi cesarskie w Polsce dokonywane sa za wiedzą i zgoda Zygmunta III ${ }^{46}$. Warto w tym miejscu zwrócić uwagę na to, że stanowisko kasztelana krakowskiego w tej sprawie różniło się od postawy księcia Krzysztofa, który na wezwanie króla gotów był wysłać swoich ludzi do zbrojnej rozprawy $z$ grasujacymi w Małopolsce lisowczykami.

Odpowiadając na list, w którym monarcha prosił go o wysłanie ludzi do walki $z$ elearami, książę koniuszy napisał, że nie tylko wyśle swoją czeladź, „która zawsze na posługe [króla - przyp. Z.A.] chowa”, lecz także sam dopomoże „do uspokojenia tych szkodliwych tumultów, tak i do usłużenia WKM". Wspomniał co prawda przy tej okazji, że „nieprzyjaciel iteratis vicibus mszcząc się wszystkich kozackich iknursyji, a particulariter [jego - przyp. Z.A.] z niewygody swojej w Konstantynopolu, złupił [mu] majętność prawie najcenniejszą, [a] co największa, wszystkę prawie czeladź w niewolę pobrał". I chociaż „mało [mu] już co tego zostało po onychże calamitates wojny przeszłej, lecz cokolwiek będzie mogło być, [rozkaże], żeby przysłuchiwać, kiedy roty WKM nastapią". Swój udział w rozprawie z lisowczykami uzależniał więc książę Krzysztof od przybycia do Małopolski wojsk kwarcianych. Ponieważ jednak wattpił w to, żeby hetman Stanisław Koniecpolski mógł dogonić lisowczyków, którzy nie mając taborów, mogliby łatwo umknać armii koronnej, radził zebrać ad hoc kilkuset ludzi pod dowództwem jakiegoś urzędnika koronnego i rozesłać uniwersały do szlachty na pospolite ruszenie. Gdyby zaś jeszcze wydano uniwersały, „że można tych łotrów impune zabijać”, to wszystko razem mogłoby sprawić, że „niejeden by zapłacił za swawoleństwo"47.

W styczniu 1624 r. (przed sejmikami poselskimi) Jerzy ks. Zbaraski poddał $\mathrm{w}$ liście do brata druzgocacej krytyce całokształt dotychczasowej polityki Zygmunta III. Oskarżał króla o skapstwo i chęć przerzucenia na obywateli wszystkich kosztów funkcjonowania państwa. Był przekonany o tym, że utrzymanie pokoju $z$ Turcją zależy niemal wyłącznie od ujęcia w ryzy Kozaków. Twierdził,

\footnotetext{
${ }^{46}$ J. Zbaraski do Zygmunta III, Pilica 30 XI 1623, Listy..., s. 81-83; Z. A nu sik, Kasztelan..., s. 88.

${ }^{47}$ K. Zbaraski do Zygmunta III, 16 XI 1623, Korespondencja..., s. 136.
} 
że w skarbie królewskim jest 700 tys. florenów, które proponował rozdzielić po połowie między armię litewską w Inflantach i koronną na Ukrainie. „Niechże dwa tysiące przyczynia kwarcianych żołnierzów lub ze trzy, wybrańce do tego, i panowie przyczynić się musza, i tem $z$ Kozaki się próbuja, bo komisjami ani żadnymi żołdami nic nie pomoże". W zakończeniu tego listu znalazło się stwierdzenie, że Zbaraski nie wybiera się na obrady sejmu, ale chciałby informację tę jak najdłużej utrzymać w tajemnicy ${ }^{48}$. Rzeczywiście też pan krakowski nie wziął udziału w nadzwyczajnym sejmie warszawskim, który obradował od 11 lutego do marca 1624 r. Na sejmie tym ksiażę Krzysztof złożył obszerną relację ze swego poselstwa do Turcji i otrzymał za nie publiczne podziękowanie. Przedstawił również traktat o stanie państwa tureckiego i plan obrony granic przez Tatarami. Obrady tego sejmu zostały jednak zdominowane przez kwestię ewentualnego wznowienia wojny ze Szwecją. Tu Zygmunt III poniósł klęskę, gdyż posłowie odmówili poparcia jego wojennych planów i żądali zażegnania konfliktu droga pertraktacji ${ }^{49}$.

Wiosną 1624 r. Jerzy ks. Zbaraski opuścił na kilka miesięcy granice Rzeczypospolitej, wyjeżdżając do Cieplic w celu poratowania zdrowia. Do kraju powrócił we wrześniu tego roku. Na list Zygmunta III w sprawie zwołania sejmu, który otrzymał we Wrocławiu, odpowiedział dopiero $z$ Myślenic. Podkreślał to, że żadna ważna dla Rzeczypospolitej sprawa nie znalazła swojego rozwiąania. Zaliczał

${ }^{48}$ J. Zbaraski do Krzysztofa Zbaraskiego, I 1624, Listy..., s. 162-165; Z. A nu sik, Kasztelan..., s. 88-89.

${ }^{49}$ Por. Przeważna legacja..., s. 199; A. Fili p czak-Ko cu r, Ksiażę..., s. 31-32; Z. Anusik, Cztery listy..., s. 470; idem, Kasztelan..., s. 89-90; Z. Trawicka, op. cit., s. 118; H. W is ne r, Zygmunt III Waza, Wrocław-Warszawa-Kraków 1991, s. 188-190; id e m, Radziwiłt Krzysztof, [w:] PSB, t. XXX, s. 278; A. Szelag ow s ki, op. cit., s. 273-280; W. Kon opczyń ski, op. cit., s. 21 (147). W przedstawionym na sejmie 1624 r. planie obrony Ukrainy przed najazdami tatarskimi Krzysztof ks. Zbaraski postulował utworzenie armii liczącej 16 tys. żołnierzy, z czego połowę stanowić mieli żołnierze zaciężni. Oprócz tego w jej skład wchodzić mieli wybrańcy (3 tys.), Kozacy oraz oddziały ordynacji ostrogskiej i ludzie starostów ukrainnych. Por. J. D oro bis z, Krzysztofa Zbaraskiego plan obrony Ukrainy przed najazdami tatarskimi, „Sprawozdania Opolskiego Towarzystwa Przyjaciół Nauk”, Wydział I, seria A, nr 23, Opole 1992, s. 31-43; P. Gawron, op. cit., s. 189. Dodajmy, że w czasie obrad sejmu 1624 r. Krzysztof ks. Zbaraski wygłosił (w zwiazku ze skazaniem Jerzego Nowodworskiego na trzy miesiące wieży za rozpowszechnianie antyjezuickiej broszury) utrzymana w bardzo stanowczym tonie mowę w obronie szlacheckiej wolności słowa i druku. Por. J. Se redyka, Sejm zawiedzionych nadziei, Opole 1981, s. 43, 56. Por. też Konstytucye seymu walnego koronnego warszawskiego R.P. 1624, [w:] Vol. leg., t. III, s. 222-235. 
do nich zagrożenie ze strony Tatarów (przy okazji gratulował królowi zwycięstwa odniesionego w dniu 20 czerwca przez hetmana polnego koronnego Stanisława Koniecpolskiego w bitwie $z$ wojskami murzy Kantymira pod Martynowem), sprawę odzyskania Inflant, ukrócenia swawoli kozackiej i pohamowania zaburzeń domowych. Najwięcej miejsca pan krakowski poświęcił sprawie ewentualnego sojuszu $z$ Szahin Girejem i wyprawy kozackiej na Krym. Nie był temu przeciwny, ale radził utrzymać cała rzecz w sekrecie, aby nie dowiedzieli się o niej Tatarzy krymscy, gdyż inaczej dostaną oni posiłki od innych ord, Turków oraz Czerkiesów i dobrze przygotuja się do obrony. Twierdził, że jeśli uda się pomyślnie załatwić problem tatarski, to wyniknie $z$ tego „i kozackie skuteczne pohamowanie i domowej swywoli wielka correctio" ${ }^{50}$.

W roku następnym stosunki braci Zbaraskich z królem uległy daleko idacemu ochłodzeniu. Jednym $z$ powodów takiego stanu rzeczy było narastanie napięcia na Ukrainie i stosunek książąt do rozgrywających się tam wydarzeń. W czerwcu 1625 r. książę Krzysztof informował Krzysztofa ks. Radziwiłła, że Kozacy zbieraja się na Niżu, skąd część uda się po raz kolejny na morze, a część wkroczy na „włości”. Na Ukrainie rozpowszechniane były pogłoski, że „pan hetman na Kozaki ma nastąpić, a to $z$ tych koniektur sobie biora, że między Czarnym a Kuczmańskim Szlakiem na Kamienicy obóz naznaczył. Chłopi szemrzą barzo i passim o jakiejś złej rezolucyjej powiadają". Pisał także o możliwości zawarcia porozumienia między Moskwa a Turcja oraz o wyjściu wojsk tatarskich w pole ${ }^{51}$. Mimo że sytuacja na kresach groziła wybuchem powstania kozackiego, w lipcu 1625 r. ksiązę koniuszy odmówił królowi wzięcia udziału w komisji kozackiej. Swoje racje wyłuszczył w obszernym liście do

50 J. Zbaraski do Zygmunta III, Myślenice 16 IX 1624, Listy..., s. 84-85. Dodajmy w tym miejscu, że ówczesny chan krymski Mehmed III popadł w konflikt z Turcją. Dnia 19 VIII 1624 r. jego brat - kałga sułtan Szahin Girej zwrócił się z listem do Rzeczypospolitej, proponujac jej „wieczne przymierze” i szereg ustępstw w istotnych dla niej sprawach. W zamian za to państwo polsko-litewskie miało jednak wyrazić zgodę na wystapienie Kozaków Zaporoskich po stronie Tatarów przeciwko Turkom. Jednym z najgorliwszych orędowników wysłania pomocy kozackiej Mehmedowi i Szahinowi Girejom był Krzysztof ks. Zbaraski. Por. J. Te odorczyk, Pogrom Kantymira, Warszawa 1972; B. Baranowski, Polska a Tatarszczyzna w latach 1624-1629, Łódź 1948, s. 31 i n.; L. Pod horod ecki, Chanat krymski i jego stosunki z Polska w XVI-XVIII w., Warszawa 1987, s. 148-149; id e m, Stanisław..., s. 120-134.

${ }^{51}$ K. Zbaraski do K. Radziwiłła, Końskowola 18 VI 1625, Korespondencja..., s. $147-148$. 
Zygmunta III: „Racz WKM sam konsyderować to, że na tę posługę tak trzeba jechać, jak na największą i najpotężniejszą wojnę, przysposobiwszy się nie tylko co do wojny należy, ale i w żywność samą, gdyż żyć $z$ sąsiedzkiego $z$ gromadą ludzi stanąwszy, nie godzi się i niebezpiecznie dla terminów prawnych, do czego czasu na przygotowanie się niemałego potrzeba. Teraz też jednę część czeladzi tak JMP krakowskiego jako i mojej posłaliśmy do JMP hetmana dla posługi WKM, drudzy też pilnuja spraw prawnych swoich po różnych rokach i naszych samych, tak $z$ prawa, jako i z pozwolenia przyjacielskiego, różnych rozjazdów, które opuścić z wielką szkoda i naszą i ich musielibyśmy i zbierać to tak nagle, o czymeśmy nie myśleli, rzecz niepodobna"52.

Odmawiając udziału w komisji kozackiej, młodszy z braci Zbaraskich nie szczędził jednak królowi rad i pouczeń. Twierdził, że kozacka swawola wiedzie prosto do wojny $z$ Turcja, a sułtan będzie chciał się rozprawić $z$ Kozakami nawet kosztem poświęcenia swoich interesów w stosunkach $z$ Persją. Kozacy zaś staja się coraz bardziej zuchwali. Pozwalaja sobie na zawieranie przymierzy z obcymi państwami (casus Mehmeda i Szahina Girejów). Twierdzą, że pokój z sułtanem zawarł król polski, ale nie oni. Kozacy czują swoja moc dzięki sławie wojennej, którą zdobyli pod Chocimiem i dzięki temu, że jest ich bardzo wielu. Poza tym moga liczyć na poparcie ze strony cerkwi dyzunickiej oraz mieszkańców kijowskiej Ukrainy i Białej Rusi. „A nadto wszystko przystąpiło ćwiczenie w używaniu broni i dzieł rycerskich $z$ częstego ćwiczenia szczęścia i nieszczęścia wojennego, $z$ bogactwem, pewnie dość znacznym". Dlatego monarcha powinien działać bardzo ostrożnie, żeby zapewnić sobie pewne zwycięstwo. Gdyby bowiem wojsko królewskie zostało pobite, „ruskie tamte wszystkie kraje, które częścia privatorum dominio uciśnione się być rozumieją, częścią też na tę unię i religię głupim swym impetem sarkaja, nieomylnie by pochop wzięli et vindictam z niemi pospołu szukali”. Do buntowników przyłączyłyby się kupy swawolne i „ci, którzy do takiego chleba apetyt mają. WKM racz brać miarę, że lada wiatr, lada praesentio pogłosu zaciagów wnet ze wszystkich państw WKM swywoleństwo pędzi nad prawa, nad zakazy WKM, nad bojaźń kary". W dalszej części swojego listu książę koniuszy radził, aby przed generalna rozprawa $z$ Kozakami zapewnić sobie spokój ze strony Turków i Tatarów. Namawiał

${ }^{52}$ K. Zbaraski do Zygmunta III, Końskowola 20 VII 1625, Korespondencja..., s. 152 . 
do rozpoczęcia rozmów $z$ sułtanem i wielkim wezyrem za pośrednictwem posłów angielskiego i francuskiego. Turcy powinni się zgodzić na wycofanie swoich wojsk znad granic Rzeczypospolitej i złożyć zapewnienie, że Tatarzy nie będą najeżdżać kresów po zniesieniu Kozaków. Jeśli jednak nie dojdzie do porozumienia $z$ Porta, w nadchodzącym roku może dojść do wybuchu wojny i wtedy Kozacy moga być potrzebni. Jeśli zaś Turcy zgodza się na porozumienie, wtedy będzie można pomyśleć o rozprawie $z$ Kozakami. Ksiażęe Krzysztof radził więc zwołać sejm, uchwalić podatki i dopiero wtedy zbrojnie egzekwować posłuszeństwo Kozaczyzny. Twierdził, że hetman Koniecpolski powinien, „nie drażniąc tej gadziny, ale raczej głaszcząc”, z całym wojskiem zostać na zimę w Kijowie lub Korsuniu. Zbaraski nie wierzył bowiem w powodzenie działań militarnych, gdyż ośmiu tysiącom żołnierzy Koniecpolskiego ciężko „ze czterdziestoma tysięcy się bić”53.

W tym samym czasie Jerzy ks. Zbaraski poróżnił się z Zygmuntem III. Zaczęło się od listu króla z 11 lipca 1625 r., w którym informował on pana krakowskiego o swoim zamiarze wyjazdu do Wilna w celu prowadzenia pertraktacji pokojowych ze Szwedami. Książę Jerzy był temu zdecydowanie przeciwny. Wyjazd monarchy na Litwę odradzał również ze względu na niepewna sytuację na Krymie i spodziewana wyprawę kozacka przeciw Turkom. I chociaż wattpił w to, by Turcy mogli zbrojnie wystąpić przeciwko Rzeczypospolitej, to nie wykluczał wybuchu wojny tureckiej. Radził zatem Zygmuntowi III, by opóźnił swój wyjazd do stolicy Wielkiego Księstwa Litewskiego przynajmniej do zimy, gdyż do tego czasu powinny się rozwiać wszelkie wątpliwości dotyczace zarówno sytuacji na pograniczu południowo-wschodnim, jak i prawdziwych zamiarów Gustawa Adolfa ${ }^{54}$.

${ }^{53}$ Ibidem, s. 153-155; A. Filipczak-Kocur, Książe..., s. 45-46.

${ }^{54}$ J. Zbaraski do Zygmunta III, Kraków 1 VIII 1625, Listy..., s. 87-89. W uzupełnieniu dodajmy, że na sejmie zwyczajnym w Warszawie (7 I-III 1625 r.) opozycja (istotna rolę odgrywał tu obok Krzysztofa ks. Radziwiłła także Krzysztof ks. Zbaraski), bezskutecznie domagając się od króla rozpatrzenia egzorbitancji, sparaliżowała obrady i uniemożliwiła przyjęcie uchwał podatkowych. W jakimś sensie ułatwiło to szwedzki atak na Inflanty, Litwę i Kurlandię w początkach lipca 1625 r. Na domiar złego 3 I 1625 r. Kozacy Zaporoscy zawarli sojusz zaczepno-odporny z Szahinem Girejem i wmieszali się do walk na Krymie. Por. Instrukcja dana posłom $z$ sejmiku przedsejmowego województwa krakowskiego $w$ Proszowicach 26 listopada 1624 r. [w:] ASWK, t. II (1621-1648), wyd. A. Przyboś, Wrocław-Kraków 1953, s. 28-37; Z. Trawicka, op. cit., s. 119-120; A. Filipczak-Kocur, Contra..., s. 273; B. Baranowski, op. cit., s. 36; W. Konopczyński, op. cit., s. 21 (147). Por. też Manifestacja posłów województwa krakowskiego na sejmie 
Nie dziwi więc to, że we wrześniu 1625 r. Jerzy ks. Zbaraski odmówił królowi udzielenia pożyczki na wyjazd do Wilna, o którą Zygmunt III zwrócił się za pośrednictwem wielkorządcy krakowskiego Stanisława Witowskiego. Przy tej okazji raz jeszcze zdecydowanie wystapił przeciwko pomysłowi podróży monarchy do stolicy Litwy: „ja przecie pro fide et munere meo proszę WKM i upominam, abyś WKM abstinere od tej drogi raczył". Stwierdzał też, że tymczasem sa inne sprawy do rozwiązania. Turcy pilnie staraja się bowiem o pokój z Persją i porozumiewają się $z$ Tatarami. Nikt tak naprawdę nie panuje nad Kozakami, na których nie komisji trzeba, a szabli. Słowem: Rzeczypospolitej grozi nowa wojna turecka, a to oznacza potrzebę rychłego zwołania sejmu, czego nie da się pogodzić $z$ planowanym wyjazdem króla na Litwę ${ }^{55}$. Jeszcze większą irytację Zygmunta III wywołać musiało uzasadnienie odmowy udzielenia władcy pożyczki przekazane przez Zbaraskiego na ręce Stanisława Witowskiego. Kasztelan krakowski podał w wątpliwość twierdzenie, że król nie ma pieniędzy. Przypomniał, że on sam był systematycznie pomijany przez władcę w dystrybucji królewszczyzn. Wyjaśniał dalej, że chociaż ojciec zostawił mu znaczny majątek, to on zmuszony jest wydawać duże sumy na utrzymanie odpowiedniego dla swego urodzenia i dostojeństwa dworu. „W wołyńskich i ukraińskich majętnościach jakową kupę ludzi chowam, z która i sam na posłudze JKMości i Rzplitej stawałem nieraz i agminatim do obozu posyłałem i posyłam, przedniejszym $z$ własnego dochodu mego, sobie od gęby odrywając i majętnościami płacąc, pośledniejszym konie, barwy, rynsztunki wszelakie wojenne za własne pieniądze kupując i żywność obmyślając. Nie wspominam fabryk, którem czynił i czynię, szkód nieznośnych, które majętności moje tak od nieprzyjaciela i od swoich odniosły". W konsekwencji odesłał króla po pożyczkę do jego faworytów ${ }^{56}$.

W kolejnym liście do monarchy, pisanym we wrześniu 1625 r., Jerzy ks. Zbaraski zajął się sytuacją polityczna na pograniczu południowo-wschodnim. Mówił o konieczności wzięcia w karby

walnym koronnym, podpisana w Warszawie 5 marca 1625 r., [w:] ASWK, t. II, s. 40-41; oraz Konstytucye seymu walnego koronnego warszawskiego R.P. 1625, [w:] Vol. leg., t. III, s. 235-236.

${ }^{55}$ J. Zbaraski do Zygmunta III, Kraków IX 1625, Listy..., s. 91-93.

${ }^{56}$ Respons ks. Zbaraskiego, pana krakowskiego, panu wielkiemu rządcy, który przyjeżdżał od króla imci fl. 100.000 na drogę litewską pożyczając, ukazując mu bezpieczna asekuracyą z najlepszych podatków - 1625 in. 7-bri, Listy..., s. 93-96; Z. Anusik, Kasztelan..., s. 94. 
Kozaczyzny oraz o poczynaniach Turków i Tatarów. Obawiał się, że jeśli hetman Koniecpolski nie zatrzyma pod sztandarami wojska na zimę, to Kozacy rozleja się po całej Ukrainie i nie będą słuchać niczyich rozkazów. Nie pokładał też pan krakowski większych nadziei w kolejnej komisji kozackiej (powołanej przez króla w lipcu 1625 r.), gdyż przewidywał, że Kozacy jak zawsze przyjmą wszystkie narzucone im warunki, po czym ich nie dotrzymaja. Sporo uwagi poświęcił natomiast sojuszowi Zaporoża z Szahin Girejem. Niebezpieczeństwo $z$ tej strony wydało mu się znacznie większe niż zagrożenie ze strony Gustawa Adolfa czy też Bethlena Gabora, o którym również wspominał w swoim liście ${ }^{57}$. Użyte przez księcia Jerzego w jednym $z$ cytowanych listów do króla słowo „upominam” wywołało tymczasem prawdziwą burzę na dworze. Zygmunt III poczuł się urażony i zażądał przeprosin. Pan krakowski tłumaczył, że upominał władce jako senator, a słowo to znaczy tyle co „przestrzegam”. Poza tym twierdził, że upominał króla wybranego na wolnej elekcji, jako obywatel wspólnej Rzeczypospolitej, zapewniał o swoim szacunku dla monarchy, ale przeprosin odmówił. Pełna dumy i nieustępliwości postawa musiała wywołać nieprzychylne wobec Zbaraskiego komentarze, skoro w obronie brata wystapił książę Krzysztof. Ten z kolei tłumaczył owo „upominam” jako „radzę”. Przywoływał przy tym instrukcje sejmikowe, w których słowo to oznaczało żądanie przestrzegania praw ${ }^{58}$.

W czasie, kiedy hetman Stanisław Koniecpolski prowadził już kampanię przeciwko Kozakom, przebywający najpewniej z dala od teatru działań wojennych książę koniuszy wysłał kolejny list do brata. Poddał w nim surowej krytyce politykę króla i hetmana na Ukrainie. Twierdził, że obawia się sojuszu kozacko-tatarskiego i boi się o los rodowych majętności na Wołyniu i Ukrainie, które moga zostać zniszczone tak przez Zaporożców, jak i niepłatnych żołnierzy. Przypomniał również warunki, które Koniecpolski zamierzał narzucić Kozakom: „nie zostawić tylko te cztery tysiące ad mentem reipublice i w tych zaraz $z$ ramienia królewskiego hetmana obrać, wziać, małe tylko praesidium na Nizie zostawiwszy. Classem wszystkę oddać i armatę, wypisać się zaraz kazać wszystkim $z$ kozactwa. Jurysdykcji, aby w miastach królewskich takiej nie wymagali, jaka mieli. Na kupy sub poena capitis nie wołać, ani na morze chodzić, być zawsze gotowym na rozkazanie hetmańskie do wojska. To są cardinalia".

${ }^{57}$ J. Zbaraski do Zygmunta III, Pilica 22 IX 1625, Listy..., s. 96-99.

${ }^{58}$ Por. A. Filipczak-Kocur, Contra..., s. 279; Z. Anu sik, Kasztelan..., s. 95. 
Zbaraski był przekonany, że nie uda się narzucić Kozakom tych warunków bez rozlewu krwi. Ci zaś, mając za sprzymierzeńców Tatarów i Moskwę, nie ustapią aż tak bardzo, mając poparcie całej dyzunickiej Rusi w sprawach religii i wiedzac o wtargnięciu do Inflant króla szwedzkiego. Książę Krzysztof przewidywał też smutny koniec wyprawy hetmana. Twierdził, że Kozacy będa przeciagać rokowania do czasu, aż wojsku zabraknie żywności i nastapią niepogody. Miasta królewskie zamkną bramy przed wojskiem koronnym i trzeba będzie „każdego miasteczka dobywać”. Ochotnicy rozjada się do domów, „wybrańcy albo pozdychaja albo pouciekaja, pieniędzy już nic dla żołnierzów nie będzie”, co może grozić zawiązaniem nowej konfederacji wojskowej. Młodszy z braci Zbaraskich dziwił się postępowaniu hetmana, który działał wbrew radom przesłanym przez niego w liście do króla. W tej sytuacji odwodził Jerzego od udziału w całej imprezie. Twierdził, że wytłumaczą się ze swojego postępowania zarówno w przypadku porażki hetmana, jak i jego sukcesu. Prosił, by Jerzy zakazał swoim sługom wzięcia udziału w wyprawie, co pozwoli im uniknać ewentualnej zemsty ze strony Kozaków. „Życzyłbym sobie i prosiłbym żebyś WM pilnego kozaka wyprawił do [kniazia Stefana - przyp. Z.A.] Czetwertyńskiego, żeby nikogo $z$ naszych nie puszczał i sam nie chodził, dawszy w liście swym rationes panu hetmanowi któreś wyraził, jeśliby się i to zdało żebyś i tę przyczynę ostatnią na mnie zwalił, żem i ja consensum praebere na to nie chciał" 59 .

Książę Jerzy nie wziął udziału w rozpoczynającym się pod koniec stycznia sejmie zwyczajnym 1626 r. ${ }^{60}$ Tłumaczył się przed królem niespodziewana choroba. Na sejmiku przedsejmowym w Proszo-

${ }^{59}$ K. Zbaraski do J. Zbaraskiego, 20 X 1625, Korespondencja..., s. 164-166. Dodajmy w tym miejscu, że czarne prognozy księcia Krzysztofa nie znalazły potwierdzenia w rzeczywistości. Inni magnaci kresowi posłali bowiem do obozu hetmana swoje nadworne poczty, co pozwoliło temu ostatniemu osaczyć Kozaków koło Jeziora Kurukowskiego. Sprawa kozacka znalazła też swoje tymczasowe rozwiąanie w narzuconej Kozaczyźnie przez Stanisława Koniecpolskiego tzw. ugodzie kurukowskiej (6 XI 1625 r.), która przewidywała obniżenie rejestru do 6000 ludzi. Ponadto Kozacy zobowiązali się zaniechać „chadzek” na Morze Czarne, przestrzegać porządku i nie wdawać się w żadne konszachty z obcymi państwami. Por. W.A. Se rczyk, Na dalekiej Ukrainie. Dzieje Kozaczyzny do 1648 r., Kraków 1984, s. 263; Z. Wój cik, Dzikie pola w ogniu. O Kozaczyźnie w dawnej Rzeczypospolitej, wyd. 2, Warszawa 1961, s. 102-104; L. Pod horodecki, Stanisław..., s. 136-144; Z. Trawicka, op. cit., s. 120; A. Fili pczak-Kocur, Ksiażę..., s. 45.

${ }^{60}$ Sejm ten obradował w Warszawie od 27 I do 6 III 1626 r. Podobnie jak na sejmach poprzednich, spora rolę odegrał na nim Krzysztof ks. Zbaraski. Spory 
wicach namawiał jednak szlachtę na wyrażenie zgody na wyższe podatki. Przewidywał duży najazd tatarski i ostrzegał, że Zaporożcy szykuja się do wyjścia na morze. Ubolewał nad tym, że sejm uchwalił zbyt małe podatki na tak wiele potrzeb Rzeczypospolitej. Zapewniał też Zygmunta III, że chociaż sam nie będzie na sejmiku relacyjnym w Proszowicach, to będzie zabiegał o uchwalenie czwartego poboru na potrzeby wojska kwarcianego na Ukrainie ${ }^{61}$.

Kiedy jednak w maju roku 1626 król poprosił Zbaraskiego o wysłanie jego ludzi do obozu hetmana polnego koronnego Stanisława Koniecpolskiego, książę zdecydowanie odmówił. Uzasadniał to w następujacy sposób: „Dwa razy w tym roku ludzie moi i brata mego byli na usłudze WKM i Rzeczypospolitej przeciwko Kozakom, czyniąc to, co im było rozkazano od imć pana hetmana $i$ jednych nabito, drugich nastrzelano i koni, nie odpoczywajac nic prawie, chodzili za chanem i tam siła we zła zimę koni nachromili i napsowali. Dispar i nierówna jest conditio ludzi Rzeczypospolitej $\mathrm{w}$ tej mierze, a privatorum Rzeczpospolita ex communi szkody takowe nagradza, i kiedy zgubi swojego stipendiarium za pieniądze pospolite łatwie drugiego dostanie. My prywatni nagradzać z swojego swoim szkody musimy, konie, barwy, rynsztunki wszelakie dawać, co jako wiele kosztuje i jako szkodę w prywatnem mieszkaniu czyni, coraz to kupując i naprawiając, a ile tych czasów, nie trzeba się $z$ tem szerzyć. Więc i kiedy przez długi czas ćwiczony, zginie człowiek, nim drugi na to miejsce urośnie i wyćwiczy się, siła czasu weźmie”. Dał już zresztą „niejeden przykład z bratem swoim ichmościom drugim, którzy i nie ucierpieli jeszcze tyle, ile ja i teraz świeżo od chana dużą dziurę w ojczyźnie swojej wziąwszy...

o egzorbitancje i tym razem doprowadziły do burzliwej dyskusji. Konieczność zapewnienia obrony kraju skłoniła jednak tak króla, jak i opozycyjnych posłów do zawarcia w tej sprawie kompromisu. Ostatecznie uchwalono też podatki na obronę Ukrainy i wojnę inflancką. Po zakończeniu sejmu opozycja wniosła do grodu warszawskiego protestację w sprawie egzorbitancji i nierozstrzygnięcia po jej myśli sporu Akademii Krakowskiej z jezuitami. Dodajmy, że umiarkowane stanowisko marszałka tego sejmu - Jakuba Sobieskiego naraziło go na poważne pogorszenie dobrych dotąd stosunków z braćmi Zbaraskimi. Por. J. Kwak, Sejm warszawski 1626 roku, Opole 1985; Z. Trawicka, op. cit., s. 121-124; U. Augustyniak, W. Sokołow ski, op. cit., s. 23-24; W. Kon o pczyńs ki, op. cit., s. 21 (147); Konstytucye seymu walnego koronnego warszawskiego R.P. 1626, [w:] Vol. leg., t. III, s. 237-250.

${ }^{61}$ J. Zbaraski do Zygmunta III, Kraków 27 III 1626, Listy..., s. 102-103. Por. też J. Kwak, op. cit., s. 118-119; A. Filipczak-Kocur, Contra..., s. 274; Z. Anusik, Kasztelan..., s. 97-98. 
Niech też spróbuja, jeśli takowa służba lekko przychodzi albo nie, i jeśli się prędko sprzykrzy, $z$ swego coraz bez ratunku mieszka sięgając"62.

Wiosną i latem 1626 r. miało się okazać, że książęta Zbarascy, nie wierząc w trwałość porozumienia $z$ Kozakami, rację mieli. W początkach lipca książę Krzysztof informował Krzysztofa ks. Radziwiłła, że Zaporożcy zorganizowali dużą wyprawę morską i złupili okolice Stambułu. W tej sytuacji $z$ dworu sułtańskiego „po odejściu kozackiem, zaraz posłano do cara [chana Mehmeda Gireja - przyp. Z.A.] $z$ szablą, kaftanem i czerwonemi złotemi, aby potężnie szli do Polski, a już też był wprzód jego brat Szahin Girej wygotował, i już dwanaście dni po bajeranie jako się mieli ruszyć". Tymczasem zaś Koniecpolski zarządził koncentrację sił polskich pod Barem, a na Sicz posłał Michała Doroszenkę z rejestrowymi, żeby ukarał tych, co byli na morzu. Doroszenko doprowadził do zniszczenia czółen kozackich, ale nie miał szans na rozprawienie się $z$ uczestnikami ostatniej wyprawy. Kozacy zostawili na Siczy 1200 ludzi, a reszta wyszła razem $z$ Doroszenka. „O generalne prosili pana hetmana odpuszczenie chcąc przyjść do niego $z$ wszystkiem wojskiem, mianowicie ci wypiszczykowie i pozwolił pan hetman, i do KJM $z$ tym posłał". W tym samym liście Zbaraski wspomniał o tym, że Bethlen Gabor zbiera wojska i szykuje się do najazdu na Polskę w sojuszu $z$ Tatarami ${ }^{63}$. W tym samym duchu pisał też do ulubieńca Zygmunta III, starosty lajskiego Kaspra Denhoffa. Ostrzegając przed zagrożeniem ze strony Tatarów oraz władcy Siedmiogrodu, twierdził, że Bethlen Gabor jest już gotowy do wojny, a Rzeczpospolita nie jest przygotowana. Jeśli Bethlen ruszy z Koszyc, to kto i czym go zatrzyma? Przy tej okazji książę Krzysztof wyraził też obawy o to, by władca Siedmiogrodu nie porozumiał się przeciwko Polsce ze

62 J. Zbaraski do Zygmunta III, 13 V 1626, Listy..., s. 103-104. W uzupełnieniu tej relacji kasztelana krakowskiego warto powiedzieć, że w lutym $1626 \mathrm{r}$. ludzie księcia Krzysztofa dowodzeni przez kniazia Stefana Czetwertyńskiego wzięli chlubny udział w walkach $z$ Tatarami pod Haliczem, przyczyniając się do odparcia najazdu prowadzonego przez samego chana. Por. Stefan Czetwertyński do K. Zbaraskiego, 23 II 1626, Korespondencja..., s. 203-204. O ekscesach kozackich w Kijowie i Trechtymirowie oraz o zagrożeniu ze strony Turcji i Tatarów informował $z$ kolei hetmana polnego litewskiego sam książę Krzysztof w kwietniu tego roku. Por. K. Zbaraski do K. Radziwiłła, Końskowola 15 IV 1626, Korespondencja..., s. 205.

${ }^{63}$ K. Zbaraski do K. Radziwiłła, Końskowola 9 VII 1626, Korespondencja..., s. 206-207. 
swoimi szwagrami - królem Szwecji Gustawem II Adolfem i elektorem brandenburskim Jerzym Wilhelmem ${ }^{64}$.

Zapewne w tym samym czasie książę koniuszy napisał list do podkanclerzego koronnego Stanisława Łubieńskiego. Informując go o zagrożeniu południowych i południowo-wschodnich granic Rzeczypospolitej, wyraził przy tej okazji obawę, żeby na państwo polsko-litewskie nie spadł najazd $z$ trzech stron w sytuacji, gdyby Bethlen Gabor uderzył na Kraków, Tatarzy na Lwów, a pasza silistryjski Mehmed Diak na Raszków. Według Zbaraskiego hetman Koniecpolski miał na Ukrainie 10 tys. ludzi i wkrótce miał się połączyć z 12-tysięczna armią kozacką Michała Doroszenki. Mając pod swoją komendą 22 tys. żołnierzy, hetman $z$ powodzeniem mógłby nie tylko bronić kresów, lecz także wspomóc przygotowania do obrony Małopolski. Ksiązę Krzysztof radził więc, aby Koniecpolski wydzielił ze swojej armii dywizję w sile 6-8 tys. husarii i Kozaków i przesuną ją ku Przemyślowi lub Krakowowi. Jej dowództwo proponował powierzyć kasztelanowi halickiemu Marcinowi Kazanowskiemu. Ten ostatni, na wypadek agresji ze strony Bethlena Gabora, powinien jednak unikać otwartej walki, ale uformowawszy tabor, obserwować poczynania wroga i iść w ślad za nim. Nie widzac innego sposobu przygotowania obrony, książę koniuszy postulował ściagnięcie nad południowa granicę prywatnych pocztów magnackich. Doradzał, żeby król napisał list do jego brata, Jerzego ks. Zbaraskiego, „żądajac, aby ludziom swoim tak z Wołynia, jako z Ukrainy, osadziwszy jako może swoje miasteczka, kazał się ku Lublinowi ruszyć, którym myśmy kazali dawno być w pogotowiu. Wiem pewnie, że tam będzie z 1000 człowieka”. Książę Krzysztof twierdził ponadto, że można będzie ściągnąć pod Kraków 600 ludzi wojewody kijowskiego Tomasza Zamoyskiego, kilkuset ludzi podczaszego koronnego Stanisława Lubomirskiego, kilkusetosobowy poczet starosty czerkaskiego Konstantego ks. Wiśniowieckiego i milicję biskupa krakowskiego Marcina Szyszkowskiego (400-500 żołnierzy). Jeśli swoich ludzi przysłaliby też kasztelan sandomierski Mikołaj Spytek Ligęza oraz inni panowie małopolscy, to zebrałoby się dodatkowo około 1000 żołnierzy. Zbaraski liczył ponadto na kilkuset ludzi, których mógłby przysłać biskup wrocławski (był nim trzynastoletni wówczas syn Zygmunta III - Karol Ferdynand Waza), na wsparcie finansowe ze strony Gdańska i Elbląga, pomoc ze strony biskupów

${ }^{64}$ K. Zbaraski do Kaspra Denhoffa, na zamku w Pilicy 12 VII 1626, Korespondencja..., s. 207-212. 
i faworytów króla oraz na pieniądze samego monarchy. Proponował także, aby wydać uniwersały na pospolite ruszenie dla województw krakowskiego i sandomierskiego. Przewidywał, że do września uda się zebrać kilkanaście tysięcy ludzi, co powinno wystarczyć do powstrzymania Siedmiogrodzian. Na wszelki wypadek prosił jednak o przysłanie $z$ Prus Królewskich 1000 żołnierzy, „co do Inflant mieli iść". Radził wreszcie na koniec, aby hetman Stanisław Koniecpolski, Jerzy ks. Zbaraski oraz Stanisław Lubomirski wyprawili do Bethlena Gabora poselstwa $z$ ostrzeżeniem, że Rzeczpospolita wie o jego wrogich zamiarach i podjęła już przygotowania do obrony ${ }^{65}$.

Wydaje się niemal pewne, że przynajmniej o niektórych swoich pomysłach dotyczacych obrony Małopolski przed spodziewanym najazdem Bethlena Gabora książę Krzysztof poinformował brata. W pisanych latem 1626 r. listach pana krakowskiego do króla pojawiaja się bowiem dość podobne propozycje. Dnia 18 lipca $1626 \mathrm{r}$. Jerzy ks. Zbaraski informował Zygmunta III o zagrożeniu południowej granicy ze strony Bethlena Gabora, Turków, Tatarów i hospodara mołdawskiego. Jego niepokój pogłębiało to, że w Małopolsce nie było żadnych sił wojskowych, a bezpieczeństwa Krakowa strzegł podstarości i 20 piechurów. Książę przewidywał, że w przypadku ataku w ciagu dwóch dni miasto znalazłoby się w rękach nieprzyjaciela. Prosił więc króla, aby wydał rozkazy Koniecpolskiemu, nakazując mu przysłać z Ukrainy nad granicę węgierska 1500 do 2000 jazdy, „a najwięcej hussarzów, bo rozumiem, że tych najmniejsza opera przeciwko Tatarom być może". Proponował również zwołanie pospolitego ruszenia województw krakowskiego, sandomierskiego i sieradzkiego oraz zawezwanie na pomoc piechoty biskupa krakowskiego i ludzi Stanisława Lubomirskiego. Sam Zbaraski obiecywał, że do zgromadzonych wojsk dołaczy swoje nadworne oddziały, aczkolwiek zastrzegał, że nie będzie to łatwe, „bo mnie widzisz WKM, jako daleko ludzi ściagać aż z Ukrainy". Zgromadzenie na granicy węgierskiej kilku tysięcy żołnierzy (książę przewidywał, że zwykła w takich razach plotka powiększy znacznie ich liczbę) powinno skutecznie zniechęcić Bethlena Gabora od podejmowania jakichś wrogich działań przeciwko Rzeczypospolitej. Do najazdu na Polskę mogłaby go skłonić jedynie porażka Stanisława Koniecpolskiego

65 K. Zbaraski do Stanisława Łubieńskiego, bez daty, Korespondencja..., s. 221-225. Dodajmy w tym miejscu, że A. Filipczak-Kocur datuje ten list „przed sejmem wiosennym 1626 r.”. W moim przekonaniu jednak list ten został napisany w pierwszej połowie lipca $1626 \mathrm{r}$. 
w walce $z$ Tatarami. Zbaraski nie dopuszczał jednak do siebie tej myśli, twierdząc, że chociaż „hetman i 2000 ludzi sobie ujmie, supplebit to zasię Kozakami, którzy bez pochyby do niego pójda, kiedy Doroszenko już się tam $z$ nim uspokoił”. W tym samym liście książę kasztelan pisał, że właśnie otrzymał wiadomość o lądowaniu wojsk szwedzkich w Prusach. Przewidywał stąd zagrożenie dla osoby króla i utrudnienia w handlu gdańskim, bez którego „Polska żadnych dostatków mieć nie może”. Sytuację uznawał za bardzo groźna, gdyż ewentualny sukces w Prusach Gustawa Adolfa mógłby zachęcić do uderzenia na Polskę jego szwagra - Bethlena Gabora ${ }^{66}$.

Kilka dni później Zbaraski ponownie ostrzegał króla, że Rzeczypospolitej grozi najazd ze strony Bethlena Gabora i Tatarów Szahin Gireja. Obaj mieliby uderzyć w jednym czasie, korzystając z tego, że Gustaw Adolf rozpoczą działania wojenne w Prusach. Ksiązę Jerzy obawiał się ataku władcy Siedmiogrodu na Kraków, a Tatarów na Ukrainę. Ponieważ wojska hetmana Koniecpolskiego znajdowały się daleko na kresach, Zbaraski raz jeszcze prosił króla o przysłanie na granice węgierska 2 tys. jazdy kwarcianej, zwołanie pospolitego ruszenia województwa krakowskiego, wyznaczenie odpowiedniego wodza i danie mu na pierwsze wydatki kilkudziesięciu tysięcy złotych ze skarbu radomskiego. Radził przy tym powierzenie dowództwa obrony Małopolski Stanisławowi Lubomirskiemu, „który i kilka set człeka swego zaraz może mieć i tu w Podgórzu ma powinowactwa i clientellą swoję mógłby prędko co ludzi zebrać". Zbaraski nalegał na pośpiech, gdyż na Spiszu widziano posła szwedzkiego jadącego do Bethlena Gabora. Twierdził jednak stanowczo, że nie będzie można zorganizować skutecznej obrony bez przysłania $z$ Ukrainy regularnych oddziałów jazdy koronnej. Radził wreszcie, aby Koniecpolski przesunął swoją armię bardziej na zachód i stanął między Kuczmańskim a Czarnym Szlakiem ${ }^{67}$.

66 J. Zbaraski do Zygmunta III, Kraków 18 VII 1626, Listy..., s. 104-107. Dodajmy w tym miejscu, że w końcu czerwca 1626 r. wojska szwedzkie opanowały Piławę, a następnie Braniewo, Frombork, Tolkmicko, Elblag (15 VII), Malbork (18 VII) i Tczew (27 VII). Por. Z. Anusik, Gustaw II Adolf, wyd. 2, Wrocław 2009, s. 157-159; idem, Kasztelan..., s. 98-100; M. Roberts, Gustavus Adolphus. A History of Sweden 1611-1632, vol. II (1626-1632), London-New York-Toronto 1958, s. 321-327; P. Skworoda, Wojny Rzeczypospolitej Obojga Narodów ze Szwecja, Warszawa 2007, s. 59-60; M. Korduba, Doroszenko Michat, [w:] PSB, t. V, Kraków 1939-1946, s. 336; L. Podhorodecki, Stanisław..., s. 167-169; A. Filipczak-Kocur, Contra..., s. 274.

67 J. Zbaraski do Zygmunta III, Kraków 22 VII 1626, Listy..., s. 107-108; Z. Anusik, Kasztelan..., s. 100. 
W dniu 1 sierpnia 1626 r. Jerzy ks. Zbaraski pisał, że właśnie otrzymał rozkazy od króla, aby w porozumieniu $z$ innymi panami małopolskimi myślał o obronie Krakowa w przypadku agresji ze strony Bethlena Gabora. Książę, nie wiedząc zapewne, że Zygmunt III realizuje pomysł podsunięty mu przez Krzysztofa ks. Zbaraskiego, nie posiadał się $z$ oburzenia. Twierdził, że obronę stolicy powinna obmyślić Rzeczpospolita, a nie prywatni obywatele. Zebrana naprędce czeladź nie zatrzyma bowiem nieprzyjaciela dysponującego regularnym wojskiem. Powinność obrony miasta i zamku krakowskiego spoczywa co prawda na wojewodzie krakowskim, ale bronić Krakowa ma on nie swoimi prywatnymi siłami, tylko wojskami Rzeczypospolitej. Stan umocnień stolicy jest zaś tak żałosny, że nawet 5-6 tys. piechoty nie obroni miasta. Trzeba zatem zorganizować obronę Krakowa przed jego murami. Radził więc książę Jerzy sięgnięcie do środków wspomnianych w jego wcześniejszych listach. Sam również deklarował pomoc, ale zastrzegał, że w przypadku nagłego ataku Siedmiogrodzian nie zdąży ściągnąć na czas swoich choragwi z Ukrainy: „Ja tych trochę ludzi, których mam tak daleko odległych, nie moge prędko dosiąc, więc i rozdzielić się z niemi muszę, bo i tam chudoby swojej odbieżeć nago, pod tak prędkim i ustawicznym nieprzyjacielem, byłaby wielka dementia". Wytknął ponadto królowi, że jego życzenie, aby kilku prywatnych obywateli powstrzymało wroga, który $z$ cesarzem „dobrze się próbował, et non sine gloria i wielkiego zysku... nie tylko jest sperandum, ale neque i mente habendum". Ponowił swoją radę, aby wziąć ze skarbu radomskiego chociaż 30 tys. złotych i przekazać te pieniądze Stanisławowi Lubomirskiemu, żeby ten zaciągnał choć 1000 jazdy. Jeśli z Ukrainy przyszłoby 2000 kwarcianych (o czym pisał wcześniej), to razem $z$ pospolitym ruszeniem krakowskim nad granica mogłoby stanąc do 6000 ludzi, a stugębna fama $z$ pewnościa podwoiłaby te siły. „Posłałem ja do swoich na Wołyń i Ukrainę, także i mój brat, aby się tu co prędzej nademknęli bliżej, cóż ja wiem, jeśli przejścia Tatarowie dopuszcza, bo i tych już co godzinę wyglądać trzeba". Kasztelan krakowski zapewniał króla, że jeśli nadejdzie Bethlen Gabor, to będzie robił $z$ bratem wszystko, co w jego mocy, licząc na wsparcie ze strony województw krakowskiego, sandomierskiego i lubelskiego. Swoim zwyczajem nie omieszkał jednak w dość przykrych słowach przypomnieć władcy, że ten nigdy nie potrafił docenić zasług braci Zbaraskich dla Rzeczypospolitej. Książę Jerzy podkreślał, że wielokrotnie stawiał się do obozu hetmanów, a przychodził 
„nie ze stem ani z 50 koni jako drudzy, ale z pułkiem znacznym... Potem teraz po kilka razów rok po roku jaka gromada ludzi moich i brata mego przychodziła do imć pana wojewody sandomierskiego [Stanisława Koniecpolskiego], dał świadectwo dobre Jegomość, jako człowiek cnotliwy et non invidus virtuti, gdzie i krwia swoją skropili dobrze jedni, posługę WKM i Rzeczypospolitej, drudzy żywot położyli. I to mnie cieszy, żem więcej uczynił, i tysiąc razów więcej, lubo się moim nieprzyjaciołom będzie zdało, że to arroganter rzekę, niźli ci, którycheś WKM, sine mea dali Bóg invidia, Bóg mi sam świadkiem, ubogacićeś raczył ad nauseam, ci niechaj i teraz pokazuja miłość swoję, którzy jako żywo ani sobą experimentum dederunt, ani kosztem najmniejszym Rzeczypospolitej nie ratowali"68.

Kilka dni później pan krakowski przesłał królowi uspokajające wieści odnośnie do Bethlena Gabora, gdyż okazało się, że jego wojska nie wkroczyły jeszcze na terytorium węierskich komitatów pozyskanych od Habsburgów na mocy traktatów pokojowych z Nikolsburga (1622) i Wiednia (1624). Mimo wyraźnego polecenia Zygmunta III, Zbaraski wstrzymał się więc $z$ wysłaniem listu do księcia siedmiogrodzkiego, gdyż jego zdaniem niezręcznie byłoby pytać Bethlena, „dlaczego wojsko do siebie gromadzi”, skoro robi to w głębi kraju. Książę zamierzał wysłać posłańca do władcy Siedmiogrodu dopiero w wypadku, gdyby pojawił się on w Koszycach. Na wieść o tym, że Zygmunt III wybiera się osobiście do Prus, aby stawić czoła szwedzkiemu najazdowi, Zbaraski zareagował bez wielkiego entuzjazmu. Radził dobrze przygotować kampanię, zadbać o bezpieczeństwo władcy i poczynić rozeznanie co do sił i zamiarów przeciwnika. Chwalił króla za pozostawienie wojsk hetmana polnego na Ukrainie. Proponował jednak, żeby Zygmunt III wezwał do siebie kasztelana halickiego Marcina Kazanowskiego, którego uważał za najlepszego kandydata do objęcia dowództwa wojsk w Prusach $^{69}$. W połowie sierpnia 1626 r. pan krakowski pojawił się na

68 J. Zbaraski do Zygmunta III, Kraków 1 VIII 1626, Listy..., s. 108-110; J. Seredyka, Sejm w Toruniu z 1626 roku, Wrocław-Warszawa-Kraków 1966, s. 17; Z. Anu sik, Kasztelan..., s. 100-102.

${ }^{69} \mathrm{~J}$. Zbaraski do Zygmunta III, Kraków 5 VIII 1626, Listy..., s. 111-112. Dodajmy w tym miejscu, że Zbaraski liczył na to, że Kazanowski obejmie dowództwo nad jazda kwarciana przeznaczona do obrony Małopolski. Jego ewentualny wyjazd do Prus uzależniał od wyjaśnienia stanowiska Bethlena Gabora i zniknięcia zagrożenia $\mathrm{z}$ jego strony. Zbaraski nie mógł wiedzieć, że Bethlen Gabor w początkach sierpnia 1626 r. wypowiedział wojnę Ferdynandowi II. Na wieść o porażkach wojsk duńskich w Niemczech władca Siedmiogrodu zawarł jednak rozejm z cesarzem, 
sejmiku proszowskim, który uchwalił podatki i podjął przygotowania do odparcia spodziewanego ataku na województwo krakowskie ze strony Bethlena Gabora ${ }^{70}$.

W listopadzie 1626 r. zebrał się sejm nadzwyczajny w Toruniu. Jerzy ks. Zbaraski, podobnie zreszta jak inni przywódcy magnackiej opozycji (Rafał Leszczyński, Krzysztof ks. Radziwiłł, Jan Tęczyński), nie pojawił się jednak w tym mieście. Być może rzeczywiście - jak sugeruje Jan Seredyka - w obliczu pojawienia się pogłosek o przejęciu przez infantkę Izabelę listów dotyczących spisków $z$ cudzoziemcami o koronę polska po Zygmuncie książę Jerzy postanowił pozostać w domu i poczekać, aż król częściowo przynajmniej ujawni treść korespondencji i wskaże dokładniej, kogo oskarża o udział w sprzysiężeniu ${ }^{71}$.

a dwa miesiące później zdecydował się na przywrócenie pokoju. Por. M. Roberts, op. cit., vol. II, s. 329; W. Felczak, Historia Wegier, wyd. 2, Wrocław 1983, s. 144; A. Przybos, Kazanowski Marcin z Kazanowa, [w:] PSB, t. XII, Wrocław-Warszawa-Kraków 1966-1967, s. 257-259. Powiedzmy także, że zastrzeżenia pana krakowskiego odnośnie do pomysłu wyjazdu króla do Prus okazały się w pełni uzasadnione, gdyż kampania 1626 r. (w wyprawie do Prus wziął też udział Krzysztof ks. Zbaraski, mimo że brat wzywał go do włączenia się do przygotowań do obrony Małopolski) nie przyniosła Zygmuntowi III żadnych poważniejszych sukcesów, a stoczona w dniach 29 IX - 1 X 1626 r. bitwa pod Gniewem zakończyła się przykra porażka wojsk polskich. Por. Z. Anusik, Gustaw II..., s. 161-164; M. Roberts, op. cit., vol. II, s. 330-332; P. Skworoda, op. cit., s. 63-64; J. Te od orczyk, Bitwa pod Gniewem (22 IX-29 IX-1 X 1626). Pierwsza porażka husarii, „Studia i Materiały do Historii Wojskowości” 1966, t. XII, cz. 2, s. 70-172; J. Se redyka, Nowe poglady na bitwe ze Szwedami pod Gniewem w 1626 r., „Zapiski Historyczne" 1969, t. XXXIV, z. 2, s. 81-95; idem, Sejm $w$ Toruniu..., s. 20; L. Pod horodecki, Stanisław..., s. 171-175.

${ }^{70}$ Por. Uchwały sejmiku województwa krakowskiego w Proszowicach 14 sierpnia 1626 r., [w:] ASWK, t. II, s. 58-61 (pod przywołanymi tu uchwałami widnieje podpis Jerzego ks. Zbaraskiego); Z. An u sik, Kasztelan..., s. 102-103.

${ }^{71}$ Sejm w Toruniu obradował od 19 XI do 3 XII 1626 r. W czasie jego obrad bardzo pożyteczna i konstruktywną rolę odegrał Krzysztof ks. Zbaraski, który wszedł do sejmowej komisji do spraw obrony i był jednym $z$ jej najaktywniejszych członków. On też zażądał ujawnienia nazwisk osób oskarżanych przez dwór o spiskowanie przeciwko królowi, nie wiedzac, że oskarżenia te kierowane są przeciwko jednemu z jego najbliższych przyjaciół - Krzysztofowi ks. Radziwiłłowi. Występując ostro przeciwko projektom reformy elekcji, książę koniuszy zgłosił jednocześnie bardzo nowoczesny projekt komputu wojsk koronnych na rok 1627. Przewidywał on zaciagnięcie 27 tys. żołnierzy (w tym 15 tys. piechoty i 5 tys. jazdy do działań w Prusach) i wydatki w kwocie ponad 8,3 mln złotych, nie licząc żołdu dla Kozaków rejestrowych, kosztów transportu armat i wydatków na „inżynierię” wojskową. Powiedzmy wreszcie, że to właśnie Krzysztof ks. Zbaraski był inicjatorem utworzenia komisji, która miała się zająć wyszukaniem nowych sposobów 
Zimą 1627 r., wróciwszy do domu z sejmu toruńskiego, książę koniuszy napisał list do podkanclerzego koronnego Stanisława Łubieńskiego. Wystąpił w nim zdecydowanie przeciwko pomysłowi użycia oddziałów kozackich do walki ze Szwedami w Prusach Królewskich. Uważał, że nie należy zaciagać ich do wojska „ani pod ich choragwiami, ani pod ich kapitanami i jeśli być może nec sub nomine Kozaków, bo kiedy ich wypisano już deposuerunt to nomen. Przy tych jeno to zostało, którzy sub oboedientiam przyszli zniecać to znowu". Młodszy $z$ braci Zbaraskich proponował, żeby wypisanych $z$ rejestru Kozaków zaciągać do pieszych choragwi węgierskich i płacić im „po 4 złote jako hajdukowi”. Obawiał się zniszczeń w czasie przemarszu oddziałów kozackich do Prus. „Będą drzeć, będą łupić i nie 2000 ich pójdzie, [bo] taborów się też nie puszczą, [a] wezmą [i] ciurów". Uważał, że w związku z planowanym ściągnięciem Zaporożców na Pomorze trzeba przypomnieć i na nowo wprowadzić surowe konstytucje sejmowe przeciwko lisowczykom. Ci bowiem jako szlachta bali się infamii, a tamci powroza, który „włożyć im na szyję trzeba”. Twierdził, że sprowadzając do Prus zwarte oddziały kozackie, zaprzepaści się wszystko to, co do tej pory osiagnięto na Ukrainie ${ }^{72}$.

W niedługim czasie po napisaniu tego listu, w dniu 6 marca 1627 r., zmarł w Końskowoli koniuszy wielki koronny Krzysztof ks. Zbaraski. Był to ogromny cios dla kasztelana krakowskiego. Ksiażę Krzysztof był bowiem nie tylko jego ukochanym bratem, lecz także najbliższym przyjacielem, powiernikiem i współpracownikiem. Podobnie jak książę Jerzy, był on zdeklarowanym przeciwnikiem prohabsburskiej polityki Zygmunta III, potępiał imprezę $z$ lisowczykami, był zwolennikiem utrzymania pokoju z Turcją i Moskwa oraz rzecznikiem tolerancji religijnej. Wielokrotnie zasiadajac $\mathrm{w}$ izbie

pozyskiwania przychodów skarbowych. Por. J. Seredyka, Sejm $w$ Toruniu..., s. 8-9, 44-45, 58, 69, 102-105, 112-115, 117-118, 132-135, 140-142, 156; U. Augustyniak, W. Sokołowski, op. cit., s. 29, 31; P. Gawron, op. cit., s. 190, 196, 201; A. Filipczak-Kocur, Contra..., s. 274 (tu błędna informacja, że Jerzy ks. Zbaraski uczestniczył w obradach sejmu toruńskiego); Z. Anusik, Kasztelan..., s. 103-104; Uchwały seymu toruńskiego dwuniedzielnego roku pańskiego 1626, [w:] Vol. leg., t. III, s. 250-259; W. Konopczyński, op. cit., s. 21 (147) podaje błędnie, że sejm w Toruniu obradował od 10 do 29 XI; podobny błąd popełnia P. Skworoda (op. cit.), s. 65.

${ }^{72}$ K. Zbaraski do S. Łubieńskiego, bez daty (I/II 1627), Korespondencja..., s. 228-230. Dodajmy w tym miejscu, że A. Filipczak-Kocur datuje ten list „po 19 I 1627 r.”. 
poselskiej, reprezentował tam zwykle interesy starszego brata. $\mathrm{Na}$ kolejnych sejmach zajmował też $z$ reguły stanowisko opozycyjne wobec polityki Zygmunta III. I aczkolwiek młodszy $z$ braci Zbaraskich nie zawsze podzielał skrajnie antyregalistyczne zapatrywania księcia Jerzego, to był jednak jego wiernym sojusznikiem niemal we wszystkich akcjach politycznych ${ }^{73}$. Warto też zaznaczyć, że Krzysztof ks. Zbaraski był żelaznym kandydatem opozycji do buławy wielkiej koronnej. Przedwczesna śmierć nie pozwoliła mu jednak sięgnać po ten upragniony urząd, do którego sprawowania miał, jak się wydaje, odpowiednie kwalifikacje.

Po bezpotomnej śmierci brata książę Jerzy odziedziczył wszystkie jego dobra, stając się największym latyfundystą na Ukrainie i jednym $z$ najpotężniejszych magnatów koronnych. U schyłku lat dwudziestych XVII w. kasztelan krakowski był najbogatszym właścicielem ziemskim na kresach Rzeczypospolitej. W skład latyfundium kasztelana krakowskiego w województwie bracławskim wchodziło 35 miast oraz około 180 wsi (19 283 dymy). W województwie kijowskim do Jerzego ks. Zbaraskiego należało sześć miast i około 30 wsi (3500-3800 dymów). W 1629 r. w jego dobrach wołyńskich znajdowało się natomiast sześć miast oraz 99 wsi (5114 dymów). Łacznie więc w swoich dobrach na Wołyniu i Ukrainie pan krakowski miał 47 miast i ponad 300 wsi, w których znajdowało się blisko 28000 gospodarstw chłopskich i mieszczańskich. Warto dodać, że pod względem liczby dymów na przełomie trzeciego i czwartego dziesięciolecia XVII w. było to największe latyfundium magnackie na kresach ${ }^{74}$.

Oprócz rozległych (o powierzchni około $8500 \mathrm{~km}^{2}$ ) i świetnie zagospodarowanych dóbr na Wołyniu i Ukrainie, kasztelan krakowski miał również niemałe dobra w Małopolsce. Po śmierci brata

${ }^{73}$ Por. W. Chomętow ski, op. cit., passim; J. Seredyka, Sejm w Toruniu..., passim; idem, Sejm zawiedzionych..., s. 8, 9, 43, 56, 102, 103; A. Filipczak- Kocur, Sejm zwyczajny z roku 1629, Warszawa-Wrocław 1979, s. 22, 67, 68, 73; eadem, Ksiażę..., passim; Z. Anusik, Cztery listy..., s. 470-471; idem, Kasztelan..., s. 108.

${ }^{74}$ Por. H. Litwin, op. cit., s. 36, 45; Z. Anusik, Struktura..., s. 237-243; idem, Szlachta..., s. 237; idem, Latyfundia..., s. 66-71; idem, Zbarascy..., s. 96-97, 102; idem, Własność ziemska $w$ województwie kijowskim $w$ świetle rejestru poborowego z 1628 roku, [w:] Między Zachodem a Wschodem, t. IV (Życie gospodarcze $w$ Rzeczypospolitej $w$ XVI-XVIII wieku), red. J. Wijaczka, Toruń 2007, s. 87-88, 92; ide m, Glosa do dziejów rodu ksiażą Ostrogskich, „Przeglad Nauk Historycznych" 2008, R. VII, nr 1, s. 201-203; idem, Kasztelan..., s. 108-110; O. Baranowycz, op. cit., s. 26, 43, 98-103. 
Krzysztofa odziedziczył bowiem klucz końskowolski w województwie lubelskim. Dobra te składały się z miasteczka Końskowoli oraz 21 wsi. Jerzy ks. Zbaraski niedługo jednak władał włością końskowolską. W kilka miesięcy po śmierci księcia koniuszego odstąpił ja bowiem Janowi Tęczyńskiemu ${ }^{75}$.

Rezygnacja $z$ Końskowoli na rzecz Tęczyńskich wiązała się bez watpienia $z$ działaniami gospodarczymi podejmowanymi przez księcia Jerzego na terenie województwa krakowskiego. Co prawda, w rejestrze poborowym z 1629 r. odnotowano w rękach kasztelana krakowskiego jedynie dobra pilickie w tym kształcie, w jakim nabył je od Padniewskich. Obejmowały one wówczas miasta Pilicę i Mrzygłód oraz 15 całych i trzy części wsi. Przypomnijmy również, że w 1618 r. Zbaraski nabył rozległe dobra łodygowickie (wsie Łodygowice, Bystra, Meszna i Wilkowice) w powiecie śląskim. Ponieważ w rejestrze poborowym z 1629 r. w ogóle nie uwzględniono powiatu ślasskiego, nie można przedstawić stanu zagospodarowania tej włości. Skądinąd jednak wiadomo, że w ciagu ostatnich kilkunastu miesięcy życia książę Jerzy dość znacznie powiększył swoje dobra w Krakowskiem, kupujac siedem wsi w powiatach proszowskim, ksiąskim i lelowskim oraz lokując na surowym korzeniu dziewięć wiosek w „państwie łodygowickim”. Nie wchodząc w dalsze szczegóły, można stwierdzić, że u schyłku życia ostatni ze Zbaraskich władał w województwie krakowskim prywatnymi dobrami obejmującymi dwa miasta i 44 wsie, nie licząc zamków w Pilicy i Smoleniu, dworów w Secygniowie i Łodygowicach, pałacu w Krakowie oraz wójtostw, sołectw, kopalń, młynów i folwarków ${ }^{76}$.

Można zatem przyjąć, że latyfundium Jerzego ks. Zbaraskiego obejmowało pod koniec jego życia 49 miast i około 330-350 wsi prywatnych (należy pamiętać o tym, że część wiosek na kresach było osadami efemerycznymi, które znikały $z$ powierzchni ziemi po kolejnych najazdach tatarskich). Był on dzięki temu drugim co do zamożności (po ordynacie ostrogskim Władysławie Dominiku ks. Zasławskim) panem w Rzeczypospolitej. Spośród innych

75 Por. Rejestr 1626, s. 136-139; Z. Anusik, Latyfundia..., s. 71; R. Szczygieł, op. cit., s. 42; J. Kurtyka, Latyfundium tęczyńskie. Dobra i właściciele (XIV-XVII wiek), Kraków 1999, s. 147.

${ }^{76}$ Por. Rejestr 1629, s. 170, 171, 175, 183-186, 190, 191; Z. Anusik, Kariery..., s. 53; id e m, Latyfundia..., s. 72-75; id e m, Kasztelan..., s. 111-113; Wstęp, [w:] Rejestr 1629, tablica V po s. XL (tu błędne obliczenia dokonane przez wydawców w odniesieniu do dóbr Zbaraskiego); Archiwum Główne Akt Dawnych w Warszawie, Metryka Koronna 180, k. 589-591v. 
magnatów koronnych jedynie Stanisław Lubomirski i Tomasz Zamoyski dysponowali dobrami porównywalnymi $z$ ogromnymi i świetnie zagospodarowanymi włościami pana krakowskiego ${ }^{77}$.

Przejęcie dóbr ziemskich po bracie i skupienie w swoim ręku całej fortuny rodu zwiększyło wyraźnie (i tak przecież bardzo duże) znaczenie polityczne Jerzego ks. Zbaraskiego, ale $z$ pewnościa nie rekompensowało mu ogromu poniesionej straty. Pograżony w bólu i żałobie, pisał jednak w połowie marca do króla, przypominając o konieczności przyspieszenia zaciagów do armii tak w Prusach, jak i na Ukrainie ${ }^{78}$. Co jednak ciekawe, będąc po śmierci Krzysztofa największym latyfundysta na kresach, zaabsorbowany innymi problemami, pan krakowski $z$ rzadka tylko poruszał w swojej korespondencji kwestie związane $z$ sytuacją na południowo-wschodnim pograniczu państwa.

W czerwcu 1627 r. Jerzy ks. Zbaraski informował króla, że Bethlen Gabor ostatecznie pojednał się $z$ cesarzem. Pisał także o niepokojach na pograniczu $z$ Turcja i wielkiej wyprawie kozackiej na Morze Czarne. Radził wykorzystać sytuację i zmusić Turków do zaprzestania budowy nowej twierdzy w okolicach Oczakowa ${ }^{79}$. Kilkanaście dni później książę Jerzy ponownie przypomniał Zygmuntowi III tę kwestię. Liczył jednak na to, że budowę nowej twierdzy pod Oczakowem uniemożliwią Kozacy. Nie obawiał się też większego zagrożenia ze strony Porty, gdyż uważał, że Turcy nie moga podjąć żadnych działań przeciwko Polsce $z$ powodu wojny $z$ Persją. Również Bethlen Gabor „roku tego pewnie quiescet i będzie patrzył eventum tych wojsk luterskich $z$ katolikami, więc i tureckiej wojny $z$ Persami" 80 .

Dopiero w początkach września 1628 r. książę Jerzy napisał do kanclerza wielkiego koronnego Jakuba Zadzika, niemal cały list poświęcając sytuacji na pograniczu południowo-wschodnim. Radził wykorzystać walki o tron w Bakczysaraju między Mehmedem III

${ }^{77}$ Gdybyśmy wzięli pod uwagę wszystkie osady wiejskie odnotowane przez źródła w dobrach należących do Jerzego ks. Zbaraskiego, byłoby to aż 368 wiosek. Bardziej realistyczny wydaje się jednak szacunek określający liczbę osad wiejskich w tym latyfundium na 330-350. Por. Z. An usik, Zbarascy..., s. 97; idem, Kariery..., s. 52; idem, Struktura..., s. 238-239; ide m, Latyfundia..., s. 75-76; idem, Glosa..., s. 201-204; idem, Kasztelan..., s. 113-114; O. Bara nowycz, op. cit., s. 25 .

${ }^{78}$ J. Zbaraski do Zygmunta III, Kraków 14 III 1627, Listy..., s. 124-125.

79 J. Zbaraski do Zygmunta III, Kraków 13 VI 1627, Listy..., s. 131-132.

${ }^{80}$ J. Zbaraski do Zygmunta III, Kraków 29 VI 1627, Listy..., s. 132-133. 
(obalonym w czerwcu 1628 r.) i Szahinem Girejami a popieranym przez Turcję chanem Dżanibekiem II i wysłać na Krym posiłki kozackie. Wszystko to należałoby jednak robić bardzo ostrożnie, żeby Turcy nie mieli żadnego dowodu na udział Rzeczypospolitej $\mathrm{w}$ tym przedsięwzięciu. Oficjalnie należy rozmawiać $z$ sułtanem o utrzymaniu pokoju, a potajemnie trzeba zachęcać Szahina Gireja do walki o tron na Krymie. Trzeba też wykorzystać zapał Kozaków, którzy chcą niezwłocznie „Szahin Gireja wnieść na państwo, Tatary mieszać [...] tak prudenti consilio choć prości chłopi, żeby i nieboszczyk Juliusz Cezar lepiej radzić nie mógł”. Zbaraski nalegał, aby wykorzystać okazję do interwencji w chanacie, póki Turcy mają ogromne kłopoty w Persji. Im zaś więcej zamieszania wśród Tatarów na Krymie, tym lepiej dla Rzeczypospolitej. A nawet gdyby przy tej okazji „też Kozaków co i nadymało, od których i samych wiele razóweśmy strach miewali, wszystko to nam salubre". Pan krakowski przestrzegał jednak kanclerza, aby wojska kwarciane regimentarza Stefana Chmieleckiego pod żadnym pozorem nie udzielały wsparcia Kozakom, gdyż to mogłoby grozić zerwaniem paktów z Turkami. Domagał się też utrzymania wszystkich poczynań Rzeczypospolitej w najgłębszej tajemnicy i powierzenia Bartłomiejowi Obałkowskiemu zadania prowadzenia sekretnych negocjacji z Kozakami. Twierdził także, że jeśli Rzeczpospolita nie wykorzysta nadarzającej się okazji do osłabienia Krymu, to „taką wojnę jadowitą i sroga od Tatarów będziem mieli, jaka przez wszystkie wieki nie bywała" ${ }^{81}$. W pisanym tego samego dnia liście do króla Zbaraski powtórzył swoje uwagi odnośnie do kwestii tatarskiej, radząc równocześnie władcy, aby wykorzystał Szahin Gireja jako narzędzie nacisku na Turcję i nowego chana krymskiego - Dżanibeka II Gireja ${ }^{82}$.

81 J. Zbaraski do Jakuba Zadzika, Kraków 9 IX 1628, Listy..., s. 137-140. Dodajmy w tym miejscu, że już latem 1628 r. wyruszyło na Krym 4 tys. Kozaków, którzy wsparli obu Girejów w walce $z$ chanem ordy nogajskiej Kantymirem, pokonali go, a następnie oblegli w Kaffie, gdzie schronił się pod opiekę Turków. Jesienia 1628 r. przybyło do Warszawy poselstwo od Mehmeda i Szahina Girejów (którzy utracili tymczasem realną władzę w chanacie). Oświadczyło ono w ich imieniu, że bracia dobrowolnie zrzekaja się „upominków”, gwarantuja Polsce pomoc wojskową oraz wypuszczaja na wolność jeńców uprowadzonych z ziem Rzeczypospolitej. Przychylne dla obu Girejów stanowisko dworu warszawskiego nie miało jednak większego wpływu na przebieg wypadków na Krymie, gdzie tymczasem armia turecka pokonała Zaporożców i umocniła tron Dżanibeka II. Por. B. Ba ra nowski, op. cit., s. 74-117; L. Podhorodecki, Chanat..., s. 151-152; Z. Anusik, Kasztelan..., s. 120-121.

82 J. Zbaraski do Zygmunta III, Kraków 9 IX 1628, Listy..., s. 136-137. 
W końcu września 1628 r. Jerzy ks. Zbaraski odradzał monarsze zwołanie pospolitego ruszenia. Po pierwsze, ze względu na późną już porę roku, po drugie dlatego, że pospolite ruszenie $z$ województw ruskich mogłoby dotrzeć do Prus dopiero późna jesienią. Brak żywności i paszy dla koni doprowadziłby jedynie do dewastacji całego królestwa, a skutek tej wyprawy byłby żaden, gdyż Szwedzi właśnie w końcu października zwykli kończyć kampanię i wracać z większością wojsk do domu. Poza tym wyprowadzenie $z$ województw ruskich pocztów magnackich i szlachty byłoby nieostrożne ze względu na spodziewane starcie Szahina Gireja i Kozaków z wojskami chana Dżanibeka II. W razie ich klęski na Ukrainę $z$ pewnością spadnie najazd tatarski, a kwarciani Chmieleckiego sa za słabi, aby samodzielnie go odeprzeć. Nie należy też lekceważyć zagrożenia ze strony Bethlena Gabora, który patrzy w kierunku Małopolski i „dyba jako złodziej na jarmark, żeby co jeno załapić mógł"83. W październiku pan krakowski odmówił królowi przysłania do Prus swoich prywatnych choragwi $z$ Ukrainy, wymawiając się zbyt dużą odległością miejsca stacjonowania tych oddziałów od pruskiego teatru działań wojennych oraz brakiem pieniędzy. Powtórzył natomiast swoją prośbę o zwołanie sejmu, gdyż wszystkie inne nadzieje królewskie uznał za „bardzo płonne" ${ }^{4}$.

W początkach 1629 r. kasztelan krakowski wziął udział w obradach sejmu zwyczajnego w Warszawie (9 stycznia - 20 lutego). Wszedł wówczas do komisji powołanej do opracowania reform monetarnych, podatkowych i wojskowych. Zbaraski był autorem przynajmniej jednego projektu podatkowego. Proponował w nim ustanowienie swego rodzaju akcyzy od sprzedaży i kupna każdego towaru. Mieli ja płacić wszyscy podatnicy, więc również przedstawiciele stanu szlacheckiego. Projekt ten nie znalazł jednak uznania w oczach sejmujacych, a do jego obalenia przyczynili się przede wszystkim posłowie litewscy. Pan krakowski był podczas tego sejmu wyjątkowo aktywny. Zgłaszał także inne projekty skarbowe, ale bez powodzenia, gdyż uważano je za zamach na system szlacheckich przywilejów (libertatibus contrariae). Kiedy zaś wreszcie przeprowadzono reformę podatkowa, uchwalając podymne, protestowali przeciw temu przedstawiciele województw kresowych wspierani przez Jerzego ks. Zbaraskiego. Oskarżano go w związku z tym,

83 J. Zbaraski do Zygmunta III, Kraków 27 IX 1628, Listy..., s. 142-144; Z. Anusik, Kasztelan..., s. 122.

${ }^{84}$ J. Zbaraski do Zygmunta III, Pilica 31 X 1628, Listy..., s. 145. 
że sprzeciwia się nowemu podatkowi, gdyż na Wołyniu i Ukrainie znajdują się jego majątki. Sądzić jednak wypada, że książę protestował przeciwko podymnemu nie tylko dlatego, że było ono bardziej uciążliwe dla jego poddanych w porównaniu $z$ obciążającym ich wcześniej łanowym. Najpewniej uznał on bowiem, że zgłoszone przez niego w trakcie obrad sejmu propozycje mogłyby przynieść skarbowi państwa większe korzyści niż nowo uchwalone podymne. Protest przeciwko podymnemu mógł być też wynikiem frustracji kasztelana krakowskiego, gdyż spośród wszystkich zgłoszonych przez niego projektów podatkowych uchwalono jedynie podatek od kupców, pobierany w formie narzutu na towary ${ }^{85}$.

Na sejmie 1629 r. pan krakowski przedstawił również własny projekt reorganizacji wojska w Prusach. Proponował jego powiększenie do liczby 23 tys. żołnierzy - 14 tys. piechoty (6000 piechoty niemieckiej, 4000 polskiej, 2000 węgierskiej, 2000 wybrańców), 1500 dragonów, 3000 Kozaków Zaporoskich i 4500 jazdy (2000 husarii, 2000 kirasjerów i 500 kozaków). Postulował zrównanie żołdu piechoty polskiej $z$ niemiecka oraz rekrutowanie do pieszych formacji drobnej szlachty $z$ Podlasia i Mazowsza, w czym nawiązywał wyraźnie do projektu zgłoszonego na poprzednim sejmie w lipcu $1628 \mathrm{r}$. Jeśli chodzi o jazdę, to książę Jerzy nie miał najlepszego zdania ani o choragwiach kozackich, ani też o rotach husarskich. Dlatego proponował utworzenie oddziałów typu kirasjerskiego, rekrutowanych spośród żołnierzy choragwi kozackich, a wyposażonych w pancerze, szyszaki, parę pistoletów oraz broń biała. Dzięki temu mieli oni dorównać jeździe szwedzkiej, z która nie potrafili walczyć Kozacy. Na polu walki kirasjerzy mieli być używani do decydujacych uderzeń w szyku zwartym („koracyr jak najgęściej iść powinien, gdyż w tym jego robur wszystka”), uzupełniając w tym względzie husarię. Koszty utrzymania 21-tysięcznej armii (nie uwzględniono piechoty wybranieckiej) Zbaraski obliczył na około 700 tys. złotych kwartalnie. Kozaków Zaporoskich zamierzał użyć do walki morskiej $z$ flotą szwedzką. Wsparci przez 10 okrętów królewskich (Zbaraski

${ }^{85}$ Dodajmy, że Zbaraski pojawił się w Warszawie dopiero 30 I 1629 r. W czasie obrad sejmu wykazywał jednak ogromną aktywność, przyczyniając się do przyjęcia szeregu pożytecznych $z$ punktu widzenia interesu państwa uchwał. Por. A. Filipczak-Kocur, Contra..., s. 276-277; eadem, Sejm..., s. 32, 60, 64-65, 84; Z. Anusik, Kasztelan..., s. 124-125; W. Konopczyński, Chronologia..., s. 21 (147); Konstytucye seymu walnego koronnego warszawskiego R.P. 1629 dnia 20 lutego, [w:] Vol. leg., t. III, s. 289-309. 
nie wiedział, że w styczniu 1629 r. eskadra Zygmunta III odpłynęła do Wismaru), Kozacy mieli zaatakować Szwedów w okolicach Piławy już na wiosnę, aby uniemożliwić Gustawowi Adolfowi lądowanie w Prusach. Innymi słowy, książę Jerzy proponował przekształcenie wojny $z$ królem szwedzkim $z$ defensywnej $w$ ofensywną, upatrując w tym klucza do zwycięstwa nad najeźdźca z północy. Przedstawiony przez Zbaraskiego projekt (wystapił przeciwko niemu hetman polny litewski Krzysztof ks. Radziwiłł, ponieważ pomijał on milczeniem problem prowadzenia działań wojennych w Inflantach) nie znalazł jednak uznania w oczach uczestników obrad i nigdy nie został wdrożony do realizacji, aczkolwiek ostatecznie sejm zgodził się na przyjęcie do służby na kolejną kampanię 23-25 tys. żołnierzy zaciężnych oraz 4-5 tys. wybrańców ${ }^{86}$.

W początkach kwietnia 1629 r. Zbaraski pisał do króla, informując go o ponownym zagrożeniu Krakowa przez Bethlena Gabora. U władcy Siedmiogrodu mieli bowiem przebywać posłowie szwedzki, turecki i moskiewski, którzy radzili mu uderzenie na Polskę. Pan krakowski tłumaczył postępowanie Stanisława Lubomirskiego, który odmówił prośbie króla, aby zajął się przygotowaniem obrony Małopolski na wypadek agresji ze strony Bethlena Gabora. Twierdził, że podjęcie się takiego dzieła prywatnymi siłami jednego obywatela byłoby oczywistym szaleństwem. Radził zatem przysłać nad granicę węgierska przynajmniej 1000 jazdy kwarcianej i kilkadziesiąt tysięcy florenów. Z ludźmi Lubomirskiego, „których też ma, i może mieć kilkanaście set tak piechoty, jako i jazdy", byłaby to siła wystarczajaca do powstrzymania uderzenia Siedmiogrodzian. Na wszelki wypadek Zbaraski proponował jednak, aby król rozesłał również uniwersały na pospolite ruszenie do województw krakowskiego, sandomierskiego i sieradzkiego, a Stefanowi Chmieleckiemu rozkazał, żeby Kozakom rejestrowym kazał uderzyć na Siedmiogród, gdyby Bethlen zdecydował się zaatakować Polskę 87 .

86 Por. A. Filipczak-Kocur, Sejm..., s. 68-74; Z. Anusik, Kasztelan..., s. 125-126; H. W is ner, Dwa polskie plany wojny szwedzkiej z 1629 r. (Projekty Jerzego Zbaraskiego i Krzysztofa Radziwiłła), „Zapiski Historyczne” 1977, t. XLII, z. 2, s. 7-23; id e m, Zygmunt III..., s. 200; P. G aw ro n, op. cit., s. 190-191, 200, 202, 204, 209; R. Skow ro n, Olivares, Wazowie i Bałtyk. Polska w polityce zagranicznej Hiszpanii w latach 1621-1632, Kraków 2002, s. 234-243; J. Pertek, Flota polska w Wismarze (1629-1632), „Przegląd Zachodni” 1954, R. X, nr 7-8, s. 413-434.

${ }^{87}$ J. Zbaraski do Zygmunta III, Kraków 9 IV 1629, Listy..., s. 148-150. 
Wiosna 1630 r. Jerzy ks. Zbaraski wysłał swoje nadworne choragwie do obozu hetmana Koniecpolskiego, który na czele wojsk kwarcianych przystapił do tłumienia buntu Kozaków Zaporoskich pod wodza Tarasa Fedorowicza. Był to ostatni przejaw jego zainteresowania kwestiami zwiazanymi $z$ sytuacja na południowo-wschodnim pograniczu Rzeczypospolitej. W początkach września pan krakowski uczestniczył natomiast w obradach sejmiku przedsejmowego w Proszowicach. Nie ulega najmniejszej nawet watpliwości, że wywarł on decydujący wpływ na treść instrukcji dla posłów krakowskich ułożonej przez uczestniczacą w obradach szlachtę. Znalazły w niej bowiem swoje odzwierciedlenie sprawy, na których załatwieniu od dawna Zbaraskiemu zależało. Posłowie krakowscy mieli więc przypomnieć w czasie obrad sejmu o naruszeniu przez króla prawa w sprawie kupna przez królową dóbr żywieckich oraz nadania jej Golubia i Brodnicy. Mieli także wrócić do innych, nierozstrzygniętych na poprzednich sejmach egzorbitancji. Ponadto mieli zażądać rozliczenia „przeszłych podatków” i obmyślić zapłatę wojsku $z$ wojny pruskiej ( $z$ obniżeniem jednak należnych mu wypłat ze względu na ubytki w szeregach). Szlachta krakowska godziła się na zatrzymanie w służbie tylko 2 tys. kwarcianych. Natomiast stanowczo żądała rozpuszczenia wszystkich oddziałów cudzoziemskich oraz zmniejszenia liczby żołnierzy w garnizonach na terenie Prus Królewskich. Proponowała także, aby „prezydia” pruskie król utrzymywał ze swoich własnych dochodów. $Z$ innych punktów instrukcji krakowskiej warto przywołać zapisy dotyczące funkcjonowania mennicy, ułożenia stosunków $z$ duchowieństwem (compositio inter statum) oraz respektowania zasad tolerancji religijnej. Ponieważ w instrukcji na sejmiki przedsejmowe Zygmunt III zapowiedział przedłożenie projektu naprawy sposobu elekcji, również ta kwestia została podniesiona w omawianym tu dokumencie. Idąc niewątpliwie za głosem księcia Jerzego, sejmik proszowski wyraził zgodę na to, aby w niczym nie naruszajac zasady elekcji i obowiązującego w tym zakresie prawa, wyznaczyć deputację $z$ grona posłów i senatorów, która miałaby przygotować projekt reformy i podać go do wiadomości sejmików. Dopiero po akceptacji $z$ ich strony projekt ten mógłby zostać przyjęty i uchwalony na następnym sejmie ${ }^{88}$.

${ }^{88}$ Por. Instrukcja dana posłom na sejm z sejmiku przedsejmowego województwa krakowskiego w Proszowicach 4 września 1630 r., [w:] ASWK, t. II, s. 119-123; W. To mkiewicz, Powstanie kozackie w roku 1630, „Przegląd Powszechny” 1930, 
Przyznać trzeba, że Zbaraski zapalił się do pomysłu dokonania reformy elekcji. Opracował nawet memoriał zatytułowany Koncept JMości Jerzego Zbaraskiego, kasztelana krakowskiego, o sposobie elekcyi królów polskich, w którym cudzoziemskich sposobów siła mianuje. Zaproponował w nim wyłączenie kandydatów cudzoziemskich i zniesienie elekcji viritim, a przeprowadzanie wyboru króla większościa głosów przez senat i izbę poselską. Swój pogląd na tę sprawę podtrzymał książę kasztelan również w trakcie obrad sejmu zwyczajnego (29 stycznia - 12 marca 1631 r.) w Warszawie. Nalegał przy tym (zgodnie $z$ treścia instrukcji proszowskiej z 4 września 1630 r.), aby nowy sposób elekcji został zatwierdzony przez sejmiki. Ostatecznie jednak sprawa reformy elekcji została pogrzebana, gdyż Zygmunt III wycofał się z lansowania tego pomysłu. Królowi zależało bowiem najbardziej na zabezpieczeniu własnych dzieci, a forsowanie siła niepopularnej wśród szlachty reformy mogło być dla nich szkodliwe. Niemniej jednak pojawienie się koncepcji zniesienia wolnej elekcji królów sprawiło, że na czele uchwał sejmu 1631 r. znalazła się konstytucja pod nazwa Warunek wolney elekcyi, reasumujacca konstytucję $z$ roku 1607 . Warto może jednak przy tej okazji dodać, że konstytucje sejmowe z 12 marca $1631 \mathrm{r}$. zawierały też wiele rozstrzygnięć zgodnych $z$ postulatami księcia kasztelana i prowadzonej przez niego szlachty krakowskiej. Dotyczy to zwłaszcza uchwał powtarzajacych stare zarzuty wobec monarchy w sprawie egzorbitancji i mennicy oraz tych, które zabezpieczały prawa innowierców, a także wyznawców prawosławia. W literaturze przedmiotu za pewnik przyjmuje się, że zaangażowanie się księcia

t. CLXXXVII, s. 104-128; Z. Wójcik, op. cit., s. 107-111; L. Podhorodecki, Stanisław..., s. 258-257; H. W is n e r, Zygmunt III..., s. 210-211; J. Se red y ka, Rzeczpospolita $w$ ostatnich latach panowania Zygmunta III (1629-1632). Zarys wewnętrznych dziejów politycznych, Opole 1978, s. 79; Z. A nu sik, Kasztelan..., s. 131-132. Trudno natomiast zgodzić z wywodem A. Filipczak-Kocur, która wyraża zdziwienie, że Zbaraski podpisał instrukcje proszowska, „chociaż rok wcześniej był zwolennikiem ofensywy w Prusach i zwycięskiego zakończenia wojny. Sądzę, że jego stanowisko zdeterminowała sytuacja finansowa Rzeczypospolitej, a nie antykrólewskie nastawienie. Rozwiały się nadzieje na reformę systemu podatkowego; dotychczasowy system nie mógł zapewnić środków na realizację takiego przedsięwzięcia”. Por. eadem, Contra..., s. 277-278. Autorka nie dostrzega bowiem faktu, że od ponad roku obowiązywał rozejm altmarski ze Szwecja (zawarty 26 IX 1629 r.) i zarówno zdaniem szlachty, jak i księcia Jerzego, który zabiegał przecież o spłatę długu wobec wojska walczacego w Prusach, nie było potrzeby myśleć o obronie prowincji, której nie groziło na razie żadne realne niebezpieczeństwo. 
Jerzego w sprawę reformy elekcji dowodzi jego regalistycznej postawy i polepszenia się jego relacji $z$ królem ${ }^{89}$.

Jeśli jednak prawdziwe jest twierdzenie Wandy Dobrowolskiej, że w ostatnich latach życia Zbaraski snuł marzenia o uzyskaniu korony po śmierci Zygmunta III $^{90}$, to na kwestię tę należy spojrzeć $z$ innej perspektywy. Nie jest bowiem bynajmniej prawda, że kasztelan krakowski popierał kandydaturę królewicza Władysława do korony po ojcu. Uważał go co prawda za lepszego kandydata od młodszych synów Zygmunta III, ale równocześnie wskazywał na możliwość wyboru władcy pochodzącego spoza polskiej rodziny panującej. Jeśli myślał o sobie, to reforma sposobu elekcji mogła oddziaływać tylko na jego korzyść. Na korzyść jednego $z$ najpotężniejszych panów w Rzeczypospolitej, magnata ogromnie popularnego wśród szlachty, senatora, który siłą swojego autorytetu i argumentów wielokrotnie wpływał na przebieg obrad izby poselskiej. Sa to jednak rzecz jasna rozważania o charakterze czysto teoretycznym. Los sprawił bowiem, że pan krakowski nie przeżył króla, którego śmierci od kilku lat wyczekiwał. Jerzy ks. Zbaraski zmarł niespodziewanie w Krakowie w dniu 30 lipca 1631 r. Podobnie jak jego młodszy brat, kasztelan krakowski nigdy nie założył rodziny. Na nim też wygasł po mieczu potężny i sławny ród książąt na Zbarażu ${ }^{91}$.

${ }^{89}$ Por. A. Filipczak-Kocur, Contra.., s. 278-279; J. Seredyka, Rzeczpospolita..., s. 59, 110-116, 141; Z. Trawicka, op. cit., s. 135; H. Wis ner, Zygmunt III..., s. 211; Z. Anusik, Kasztelan..., s. 132-133; W. Konopczyński, Chronologia..., s. 21 (147); Konstytucye seymu walnego koronnego R.P. 1631 dnia 12 marca, [w:] Vol. leg., t. III, s. 318.

${ }^{90}$ Por. W. Dobrowols ka, Młodość..., s. 21, 25.

${ }^{91}$ Por. Zabytki sztuki w Polsce, t. I (Kraków, kościół i klasztor OO. Dominikanów), oprac. L. Lepszy i S. Tomkowicz, Kraków 1924, s. 44; W. Cza plińs s ki, Władysław IV i jego czasy, wyd. 2, Warszawa 1976, s. 91; Z. Anusik, Zbarascy..., s. 96; idem, Kasztelan..., s. 133. Józef Wolff (op. cit., s. 618) podaje błędnie, że śmierć Zbaraskiego nastapiła w dniu 4 VII $1631 \mathrm{r}$. Warto może w tym miejscu dodać, że mieszkający podówczas w Krakowie słynny Walerian Nekanda Trepka utrzymuje, że książę Jerzy został otruty z inspiracji zamieszanych w oszustwa i machinacje monetarne braci Szembeków: „Książę, że już złej woli był na Szemboków, który do ich przedsięwziętego ślachectwa przeszkoda za to byłby im, oni naprawili na to pania jednę, która bywała u książęcia, przedarowali i dodali trucizny, co otruła książę, pana zacnego, iż umarł anno 1631 Iulii 29”. Por. W. N e ka n da Trepka, Liber generationis plebeanorum („Liber chamorum”), cz. 1 (Wstepy wydawców i tekst), wyd. W. Dworzaczek, J. Bartyś, Z. Kuchowicz, red. W. Dworzaczek, Wrocław-Warszawa-Kraków 1963, s. 546. 
Książęta Jerzy i Krzysztof Zbarascy z pewnością moga być zaliczeni do grona najwybitniejszych polityków polskich pierwszej połowy XVII w. Potomkowie starej i ogromnie bogatej rodziny magnackiej, wykształceni, oczytani, znajacy obce kraje, władajacy kilkoma obcymi językami, mieli wielkie szanse na to, aby zrobić szybka i błyskotliwą karierę. Posiadany majątek, pochodzenie społeczne i niepospolite walory umysłowe predestynowały ich do odgrywania pierwszorzędnej roli na arenie politycznej. Niechęć ze strony Zygmunta III uniemożliwiła im jednak sięgnięcie po najwyższe urzędy państwowe. Pomijani przez króla w dystrybucji godności i starostw, obaj Zbarascy z konieczności znaleźli się więc w szeregach opozycji.

Jako właściciele wielkich majątków na kresach książęta na Zbarażu $z$ natury rzeczy musieli być zainteresowani zarówno sytuacja na Ukrainie, jak i stosunkami $z$ państwami graniczącymi $\mathrm{w}$ tym regionie $z$ Rzeczapospolitą. $W$ połowie drugiego dziesięciolecia XVII w. popadli w konflikt $z$ hetmanem Stanisławem Żółkiewskim. Występowali przeciwko niemu nie tylko dlatego, że Żółkiewski nie radził sobie $z$ utrzymaniem porządku na kresach i $z$ organizacja obrony przed Tatarami, lecz także dlatego, że byli przeciwni eskalacji konfliktu $z$ Turcja, do czego nieuchronnie prowadziła polityka realizowana przez króla i hetmana. Zbarascy byli bowiem przekonani o tym, że Rzeczpospolita nie powinna wojować $z$ sułtanem. Konsekwentnie też opowiadali się za utrzymaniem pokoju z Porta. Nawet po klęsce wojsk hetmana Żółkiewskiego w 1620 r. książę Jerzy namawiał monarchę do szukania porozumienia $z$ Turkami. Po zwycięskiej obronie Chocimia obaj bracia nalegali na szybkie zatwierdzenie zawartego w obozie pokoju. Mieli też swój istotny udział w przyjęciu przez Turcję paktów chocimskich (wielka legacja księcia Krzysztofa do Stambułu). Swojego stosunku do państwa sułtanów nie zmienili też $\mathrm{w}$ kolejnych latach. Utrzymanie pokojowych stosunków $z$ Imperium Osmańskim uważali za jeden $z$ priorytetów polityki zagranicznej Rzeczypospolitej.

$\mathrm{Na}$ kwestię stosunków $\mathrm{z}$ Chanatem Krymskim książęta Zbarascy patrzyli przez pryzmat polityki tureckiej. Władców Krymu uważali za wykonawców polityki Stambułu i narzędzie służące sułtanom do wywierania nacisku na Rzeczpospolita. Opowiadali się za tym, by nie prowokować Tatarów i unikać wszystkiego, co mogłoby zachęcić chana do najazdów na kresy. Jako właściciele majątków pustoszonych przez tatarskie czambuły, brali jednak czynny 
udział w walkach $z$ ordyńcami. Dążąc do zapewnienia skutecznej obrony ziem ruskich Korony przed Tatarami, gotowi byli zaakceptować pewne ustępstwa wobec Kozaczyzny Zaporoskiej. W latach 1624-1628 bracia Zbarascy namawiali Zygmunta III do poparcia walczących o władzę na Krymie Mehmeda i Szahina Girejów oraz do zaakceptowania ich sojuszu z Kozakami. Uważali bowiem, że podsycanie wojny domowej na Krymie będzie pod każdym względem korzystne dla interesów Rzeczypospolitej (zajęci bratobójczymi walkami Tatarzy nie będą najeżdżać na Ukrainę). Chcieli jednak, aby polska ingerencja $\mathrm{w}$ ten konflikt była jedynie pośrednia i zakulisowa. Miało to zapobiec pojawieniu się jakichkolwiek napięć w stosunkach $z$ Turcja.

Bardzo ciekawy był też stosunek braci Zbaraskich do Kozaczyzny Zaporoskiej. Również na ten problem patrzyli oni bowiem przez pryzmat stosunków z państwem padyszacha. Przyznać trzeba, że obaj książęta uważali Kozaków za buntowników, burzycieli porządku wewnętrznego i awanturników, którzy swoim postępowaniem (wyprawy na czarnomorskie wybrzeża Imperium Osmańskiego) zmierzali wprost do sprowokowania wojny $z$ sułtanem. $Z$ tego m.in. powodu Jerzy i Krzysztof ks. Zbarascy nie akceptowali polityki pobłażania Kozakom w okresie przed wyprawą cecorską. W czasie wojny chocimskiej bez wahania opowiedzieli się jednak za współpraca wojskową z Zaporożcami. Po zawarciu pokoju z Turcja, zarówno sami, jak i za pośrednictwem króla i hetmana Stanisława Koniecpolskiego, starali się nakłonić Kozaków do zaniechania "chadzek" na Morze Czarne. Obaj bracia bardzo szybko dostrzegli niebezpieczeństwo, jakie niosło ze soba nielegalne wskrzeszenie hierarchii dyzunickiej przez patriarchę jerozolimskiego Teofanesa. Sojusz prawosławnych władyków $z$ Kozaczyzną uznali za poważne zagrożenie dla interesów Rzeczypospolitej na Ukrainie. Książęta ze Zbaraża odnosili się do mołojców z poczuciem wyższości i z pogardą. Doceniali jednak siłę wojskowa Kozaczyzny. W momentach zagrożenia granic państwa (podobnie jak ogromna większość społeczeństwa szlacheckiego) gotowi byli odwołać się do pomocy Zaporożców. Częściej jednak podsuwali królowi pomysły, których realizacja mogła doprowadzić do znacznego osłabienia siły bojowej wojsk kozackich. Namawiając np. Zygmunta III do zaangażowania się w wojnę domową na Krymie, dopuszczali możliwość zniszczenia w tych walkach armii zaporoskiej. Bracia Zbarascy opowiadali się bowiem w gruncie rzeczy za polityką twardej ręki wobec mołojców. Książę Jerzy 
wielokrotnie powtarzał, że na Kozaków nie trzeba żadnych komisji, tylko szabli. Niemniej jednak książęta ze Zbaraża czuli respekt przed liczna i bitna armia kozacką. Bali się zniszczenia swoich majątków w przypadku, gdyby Zaporożcy zdecydowali się ruszyć „na włości”. $Z$ tego też powodu, nie wierząc w sukces działań prowadzonych na Ukrainie przez hetmana Stanisława Koniecpolskiego, książę Krzysztof namawiał brata do niewysyłania posiłków do obozu wojsk koronnych jesienia 1625 r. Po zawarciu ugody kurukowskiej młodszy $z$ braci Zbaraskich żądał jednak rygorystycznego przestrzegania jej warunków, występując gwałtownie przeciwko pomysłowi użycia wojsk kozackich (rekrutowanych spoza rejestru) w działaniach wojennych na terenie Prus Królewskich.

Warto też zwrócić uwage na to, że bracia Zbarascy stosunkowo niewiele uwagi poświęcali sytuacji w księstwach naddunajskich - Mołdawii i Wołoszczyźnie. Śledzili natomiast poczynania władcy Siedmiogrodu - Bethlena Gabora. Ten ostatni interesował ich $z$ dwóch powodów. Po pierwsze, jako wierny i oddany sułtanowi lennik turecki. Po drugie, jako szwagier wojujaccego $z$ Polska Gustawa II Adolfa. Posiadajac dobra w województwach krakowskim i lubelskim, książęta ze Zbaraża obawiali się ewentualnej agresji Bethlena Gabora na Małopolskę właściwą. Pod koniec trzeciego dziesięciolecia XVII w. przedstawiali też królowi własne pomysły dotyczace przygotowania obrony tej prowincji.

Bardzo ciekawa wydaje się również konstatacja, że po śmierci brata, kiedy to odziedziczywszy jego majątki, został najpotężniejszym latyfundysta na kresach Rzeczypospolitej, Jerzy ks. Zbaraski w dużo mniejszym stopniu interesował się sytuacją w tamtym regionie. Jego uwage absorbowały bowiem w tym czasie zupełnie inne problemy. Warto zresztą dodać, że również we wcześniejszym okresie problematyka pogranicza południowo-wschodniego nie stanowiła bynajmniej głównego przedmiotu zainteresowania braci Zbaraskich. Byli oni bowiem politykami, którzy próbowali wpływać na całokształt tak wewnętrznej, jak i zagranicznej polityki państwa. Atak wojsk Gustawa II Adolfa na Prusy w 1626 r. uzmysłowił jednak panu krakowskiemu, że w wojnie ze Szwecją chodzi już nie tylko o konflikt dynastyczny w rodzinie Wazów, lecz o najbardziej żywotne interesy Rzeczypospolitej. $Z$ tego właśnie powodu zmienił on swoje stanowisko w wielu kwestiach. Wielbiciel wolności szlacheckich i zdeklarowany konserwatysta, zdał sobie wówczas sprawę $z$ konieczności przeprowadzenia szeregu reform - w pierwszym 
rzędzie wojskowych i skarbowych (w prace nad tymi reformami zaangażował się również książę Krzysztof). Nie cofnął się też przed poparciem niepopularnej wśród szlachty reformy sposobu elekcji. Był przy tym książę Jerzy rzecznikiem utrzymania ładu i porządku, respektu dla władzy oraz poszanowania dla obowiazującego prawa. Dlatego tak ostro występował przeciwko rabującym kraj lisowczykom, Kozakom i konfederatom wojskowym. $Z$ tego samego powodu piętnował niezgodne $z$ prawem działania Zygmunta III, spisywane $\mathrm{w}$ formie egzorbitancji na kolejnych sejmach. Poglądy wyznawane przez Zbaraskiego zapewniały mu ogromna popularność wśród szlachty. O popularność tę książę Jerzy bardzo zręcznie zreszta zabiegał. Obaj bracia Zbarascy byli bowiem wybitnymi publicystami, którzy zabierali głos w każdej poważniejszej kwestii politycznej. Ich pisma, pełne erudycji i temperamentu, miały też często decydujacy wpływ na urabianie opinii szlacheckiej. Jest sprawą oczywistą, że Zbarascy schlebiali szlachcie, ale potrafili też narzucać jej swoje własne, $z$ reguły zbieżne $z$ interesem państwa, przekonania. Ich śmierć $z$ pewnością stanowiła ogromną stratę dla interesów państwa i w sposób negatywny wpłynęła na kształt sceny politycznej Rzeczypospolitej na przełomie trzeciego i czwartego dziesięciolecia XVII w.

\section{Bibliografia}

\section{$\dot{Z}_{\text {RÓdea ARCHIWALNE }}$}

Archiwum Główne Akt Dawnych w Warszawie (AGAD)

Metryka Koronna (MK) 180

\section{$\dot{Z}_{\text {RÓDEA DRUKOWANE }}$}

Akta sejmikowe województwa krakowskiego, t. I (1572-1620), wyd. S. Kutrzeba, Kraków 1932.

Akta sejmikowe województwa krakowskiego, t. II (1621-1648), wyd. A. Przyboś, Wrocław-Kraków 1953.

Listy księcia Jerzego Zbaraskiego kasztelana krakowskiego z lat 1621-1631, wyd. A. Sokołowski, Scriptores Rerum Polonicarum, t. V, Kraków 1880.

Ossoliński Z., Pamiętnik, oprac. J. Długosz, Warszawa 1983.

Przeważna legacja Krzysztofa Zbaraskiego, koniuszego wielkiego koronnego, do Turcji w r. 1622, [w:] Dyplomaci w dawnych czasach. Relacje staropolskie z XVI-XVIII stulecia, oprac. A. Przyboś i R. Żelewski, Kraków 1959, s. 196-206. 
Rejestr poborowy województwa krakowskiego z roku 1629, oprac. W. Domin, J. Kolasa, E. Trzyna, S. Żyga, red. S. Inglot, Wrocław 1956.

Rejestr poborowy województwa lubelskiego (powiat lubelski i urzędowski z r. 1626, ziemia łukowska z r. 1620), oprac. J. Kolasa i K. Schuster, red. S. Inglot, Wrocław 1957.

Starowolski S., Polska albo opisanie położenia Królestwa Polskiego, wyd. A. Piskadło, Kraków 1976.

Trepka Nekanda W., Liber generationis plebeanorum („Liber chamorum”), cz. 1 (Wstępy wydawców i tekst), wyd. W. Dworzaczek, J. Bartyś, Z. Kuchowicz, red. W. Dworzaczek, Wrocław-Warszawa-Kraków 1963.

Volumina legum, t. III, wyd. J. Ohryzko, Petersburg 1859.

Źródła dziejowe, t. XX (Polska XVI wieku pod względem geograficzno-statystycznym, t. IX, Ziemie ruskie. Ukraina [Kijów-Bracław]), wyd. A. Jabłonowski, Warszawa 1894.

\section{Opracowania}

Anusik Z., Cztery listy księcia Krzysztofa Zbaraskiego do prymasa Wawrzyńca Gembickiego z lat 1620-1623, „Przegląd Historyczny” 1991, t. LXXXII, z. 3-4, s. 469-479.

Anusik Z., Glosa do dziejów rodu książąt Ostrogskich, „Przegląd Nauk Historycznych" 2008, R. VII, nr 1, s. 127-210.

Anusik Z., Gustaw II Adolf, wyd. 2, Wrocław 2009.

Anusik Z., Kariery faworytów królewskich a kariery opozycjonistów w dobie panowania Zygmunta III (1587-1632), „Przegląd Nauk Historycznych” 2004, R. III, nr 2 (6), s. 5-62.

Anusik Z., Kasztelan krakowski Jerzy ks. Zbaraski (1574-1631). Szkic do portretu antyregalisty, „Przeglad Nauk Historycznych” 2010, R. IX, nr 1, s. 55-138.

Anusik Z., Latyfundia ksiażąt Zbaraskich w XVI i XVII wieku, „Przegląd Nauk Historycznych" 2009, R. VIII, nr 1, s. 17-77.

Anusik Z., Struktura społeczna szlachty bracławskiej $w$ świetle rejestru podymnego z 1629 roku, „Przegląd Historyczny” 1985, t. LXXVI, z. 2, s. 233-253.

Anusik Z., Szlachta polska na Ukrainie w latach 1569-1648. Kilka uwag na marginesie książki Henryka Litwina, „Przegląd Nauk Historycznych” 2002, R. I, nr 2, s. 231-250.

Anusik Z., Własność ziemska w województwie kijowskim $w$ świetle rejestru poborowego z 1628 roku, [w:] Miedzy Zachodem a Wschodem, t. IV (Życie gospodarcze $w$ Rzeczypospolitej $w$ XVI-XVIII wieku), red. J. Wijaczka, Toruń 2007, s. $81-112$.

Anusik Z., Zbarascy i Kalinowscy. Karta z dziejów wielkiej własności ziemskiej na kresach Rzeczypospolitej w pierwszej połowie XVII wieku, [w:] Między Zachodem a Wschodem, t. III (Etniczne, kulturowe i religijne pogranicza Rzeczypospolitej $w$ XVI-XVIII wieku), red. K. Mikulski i A. Zielińska-Nowicka, Toruń 2006, s. $74-105$. 
Anusik Z., Z korespondencji księcia Krzysztofa Zbaraskiego z arcybiskupem gnieźnieńskim Wawrzyńcem Gembickim, [w:] idem, Studia i szkice staropolskie, Łódź 2011, s. 68-84.

Augustyniak U., Sokołowski W., Wstęp, [w:] „Spisek orleańsk” z lat 1626-1628, oprac. U. Augustyniak, W. Sokołowski, Warszawa 1990, s. 5-73.

Baranowski B., Polska a Tatarszczyzna w latach 1624-1629, Łódź 1948.

Baranowycz O., Zaludnienija wołynskogo wojewodstwa w pierszij połowyni XVII st., Kyjw 1930.

Boniecki A., Poczet rodów w Wielkiem Księstwie Litewskim w XV i XVI wieku, Warszawa 1887.

Chłapowski K., Elita senatorsko-dygnitarska Korony za czasów Zygmunta III $i$ Władysława IV, Warszawa 1996.

Chłapowski K., Realizacja reform egzekucji dóbr 1563-1665. Sprawa zniesienia zastawów królewszczyzn małopolskich, Warszawa 1984.

Chłapowski K., Starostowie w Małopolsce 1565-1668, [w:] Społeczeństwo staropolskie, t. IV, red. A. Izydorczyk i A. Wyczański, Warszawa 1986, s. 105-178.

Chomętowski W., Ksiązę Krzysztof Zbaraski, koniuszy koronny, „Biblioteka Warszawska" 1865, t. III, s. 1-14, 424-428, t. IV, s. 142-174, 451-509.

Czapliński W., J. Długosz J., Życie codzienne magnaterii polskiej w XVII wieku, Warszawa 1976.

Czapliński W., Władysław IV i jego czasy, wyd. 2, Warszawa 1976.

Dobrowolska W., Książęta Zbarascy w walce z hetmanem Żółkiewskim, Kraków 1930.

Dobrowolska W., Młodość Jerzego i Krzysztofa Zbaraskich (Z wstępem o rodzie Zbaraskich i życiorysem Janusza Zbaraskiego wojewody bracławskiego), Przemyśl 1927.

Dorobisz J., Jakub Zadzik (1582-1642), Opole 2000.

Dorobisz J., Krzysztofa Zbaraskiego plan obrony Ukrainy przed najazdami tatarskimi, „Sprawozdania Opolskiego Towarzystwa Przyjaciół Nauk”, Wydział I, seria A, nr 23, Opole 1992, s. 31-43.

Drozdowski M., Religia i Kozaczyzna Zaporoska $w$ Rzeczypospolitej $w$ pierwszej połowie XVII wieku, Warszawa 2008.

Dworzaczek W., Hetman Jan Tarnowski. Z dziejów możnowładztwa małopolskiego, Warszawa 1985.

Dzieduszycki M., Krótki rys dziejów i spraw Lisowczyków, t. I-II, Lwów 1843-1844.

Felczak W., Historia Wegier, wyd. 2, Wrocław 1983.

Filipczak-Kocur A., Contra majestatem czy pro publico bono? Jerzy Zbaraski, kasztelan krakowski 1621-1631, [w:] Faworyci i opozycjoniści. Król a elity polityczne w Rzeczypospolitej XV-XVIII wieku, red. M. Markiewicz i R. Skowron, Kraków 2006, s. 261-282.

Filipczak-Kocur A., Ksiaże Krzysztof Zbaraski (1579-1627). Szkic biograficzny, [w:] Korespondencja księcia Krzysztofa Zbaraskiego koniuszego koronnego 1612-1627, oprac. A. Filipczak-Kocur, Opole 2015, s. 9-80

Filipczak-Kocur A., Sejm zwyczajny z roku 1629, Warszawa-Wrocław 1979. 
Gawron P., Projekty reform armii Rzeczypospolitej $w$ latach 20. XVII w. na tle wojskowości zachodnioeuropejskiej, [w:] Staropolski oglad świata. Rzeczpospolita między okcydentalizmem a orientalizacja, t. I (Przestrzeń kontaktów), red. F. Wolański, R. Kołodziej, Toruń 2009, s. 183-213.

Gruszecki A., Zamki bastionowe w Małopolsce, Warszawa 1962.

Konopczyński W., Chronologia sejmów polskich 1493-1793, Kraków 1948.

Korduba M., Doroszenko Michat, [w:] Polski słownik biograficzny, t. V, Kraków 1939-1946, s. 336.

Kotarski H., Kalinowski Idzi, [w:] Polski słownik biograficzny, t. XI, Wrocław-Warszawa-Kraków 1964-1965, s. 454-455.

Kowalska H., Padniewski Wojciech, [w:] Polski słownik biograficzny, t. XXV, Wroclaw 1980, s. 7-8.

Kudelka F., Bitwa pod Humiennem, „Przegląd Powszechny” 1902, t. LXXXV, s. $187-199$.

Kurtyka J., Latyfundium tęczyńskie. Dobra i właściciele (XIV-XVII wiek), Kraków 1999.

Kwak J., Sejm warszawski 1626 roku, Opole 1985.

Litwin H., Napływ szlachty polskiej na Ukraine 1569-1648, Warszawa 2000.

Lulewicz H., Sapieha Lew, [w:] Polski słownik biograficzny, t. XXXV, Warszawa-Kraków 1994, s. 84-104.

Majewski R., Cecora rok 1620, Warszawa 1970.

Majewski W., Konaszewicz (Kunaszewicz) Sahajdaczny Piotr, [w:] Polski słownik biograficzny, t. XIII, Wrocław-Warszawa-Kraków 1967-1968, s. 484-486.

Miłobędzki A., Architektura polska XVII wieku, t. I, Warszawa 1980.

Morzy J., Kryzys demograficzny na Litwie i Białorusi w II połowie XVII wieku, Poznań 1965.

Nagielski M., Sieniawski Adam Hieronim, [w:] Polski słownik biograficzny, t. XXXVII, Warszawa-Kraków 1996-1997, s. 100-102.

Opaliński E., Faworyci Zygmunta III a urzad podkomorzego koronnego, [w:] Faworyci i opozycjoniści. Król a elity polityczne $w$ Rzeczypospolitej XV-XVIII wieku, red. M. Markiewicz i R. Skowron, Kraków 2006, s. 245-259.

Pertek J., Flota polska w Wismarze (1629-1632), „Przeglad Zachodni” 1954, R. X, nr 7-8, s. 413-434.

Pietrzak J., Konfederacja lwowska w 1622 roku, „Kwartalnik Historyczny” 1973, R. LXXX, z. 4, s. 845-871.

Pietrzak J., Piekarski Michat, [w:] Polski słownik biograficzny, t. XXVI, Wrocław 1981, s. 73-74.

Pietrzak J., Po Cecorze i podczas wojny chocimskiej. Sejmy z lat 1620 i 1621, Wrocław 1983.

Pietrzak J., W przygaszonym blasku wiktorii chocimskiej. Sejm z 1623 roku, Wroclaw 1987.

Podhorodecki L., Chanat krymski i jego stosunki z Polska w XVI-XVIII w., Warszawa 1987. 
Podhorodecki L., Jan Karol Chodkiewicz 1560-1621, Warszawa 1982.

Podhorodecki L., Stanisław Koniecpolski ok. 1592-1646, Warszawa 1978.

Podhorodecki L., Raszba N., Wojna chocimska 1621 r., Kraków 1979.

Polak W., O Kreml i Smoleńszczyzne. Polityka Rzeczypospolitej wobec Moskwy w latach 1607-1612, Torun 1995.

Przyboś A., Kazanowski Marcin, [w:] Polski słownik biograficzny, t. XII, Wrocław-Warszawa-Kraków 1966-1967, s. 257-259.

Przyboś A., Komorowski Mikołaj, [w:] Polski słownik biograficzny, t. XIII, Wrocław 1967-1968, s. 426-427.

Roberts M., Gustavus Adolphus. A History of Sweden 1611-1632, vol. I-II, London-New York-Toronto 1953-1958.

Rzońca J., Ostatni sejm przed Cecora (w roku 1619), „Pamiętnik Biblioteki Kórnickiej" 1983, z. 20, s. 5-91.

Serczyk W.A., Na dalekiej Ukrainie. Dzieje Kozaczyzny do 1648 r., Kraków 1984.

Seredyka J., Nowe poglądy na bitwe ze Szwedami pod Gniewem w 1626 r., „Zapiski Historyczne" 1969, t. XXXIV, z. 2, s. 81-95.

Seredyka J., Rzeczpospolita $w$ ostatnich latach panowania Zygmunta III (16291632). Zarys wewnętrznych dziejów politycznych, Opole 1978.

Seredyka J., Sejm w Toruniu z 1626 roku, Wrocław-Warszawa-Kraków 1966.

Seredyka J., Sejm z 1618 roku, Opole 1988.

Seredyka J., Sejm zawiedzionych nadziei, Opole 1981.

Skowron R., Olivares, Wazowie i Bałtyk. Polska w polityce zagranicznej Hiszpanii w latach 1621-1632, Kraków 2002.

Skworoda P., Wojny Rzeczypospolitej Obojga Narodów ze Szwecja, Warszawa 2007.

Suwara F., Przyczyny i skutki klęski cecorskiej 1620 r., Kraków 1930.

Szczygieł R., Od lokacji do upadku szlacheckiej Rzeczypospolitej, [w:] Dzieje Końskowoli, red. R. Szczygieł, Lublin 1988.

Szelagowski A., Ślask i Polska wobec powstania czeskiego (Sprawa północna $w$ wiekach XVI i XVII, cz. 2), Lwów 1904.

Teodorczyk J., Bitwa pod Gniewem (22 IX-29 IX-1 X 1626). Pierwsza porażka husarii, „Studia i Materiały do Historii Wojskowości” 1966, t. XII, cz. 2, s. 70-172.

Teodorczyk J., Pogrom Kantymira, Warszawa 1972.

Tomkiewicz W., Powstanie kozackie w roku 1630, „Przegląd Powszechny” 1930, t. CLXXXVII, s. 104-128.

Trawicka Z., Jakub Sobieski 1591-1646. Studium z dziejów warstwy magnackiej w Polsce doby Wazów, Kraków 2007.

Tretiak J., Historia wojny chocimskiej (1621), Kraków 1921.

Tyszkowski K., Borodawka Nerodowicz Jakób (Jacko), [w:] Polski słownik biograficzny, t. II, Kraków 1936, s. 342

Urzędnicy centralni i nadworni Polski XIV-XVIII wieku. Spisy, oprac. K. Chłapowski, S. Ciara, Ł. Kądziela, T. Nowakowski, E. Opaliński, G. Rutkowska, T. Zielińska, red. A. Gąsiorowski, Kórnik 1992. 
Wasilewski T., Radziwiłł Janusz, [w:] Polski słownik biograficzny, t. XXX, Wrocław 1987, s. 202-208.

Wisner H., Dwa polskie plany wojny szwedzkiej z 1629 r. (Projekty Jerzego Zbaraskiego i Krzysztofa Radziwiłła), „Zapiski Historyczne” 1977, t. XLII, z. 2, s. 7-23.

Wisner H., Dyplomacja polska w latach 1572-1648, [w:] Historia dyplomacji polskiej, t. II (1572-1795), red. Z. Wójcik, Warszawa 1982, s. 5-161.

Wisner H., Radziwiłt Krzysztof, [w:] Polski słownik biograficzny, t. XXX, Wrocław 1987, s. 276-283.

Wisner H., Zygmunt III Waza, Wrocław-Warszawa-Kraków 1991.

Wiśniewski J., Historyczny opis kościołów, miast, zabytków i pamiątek w Olkuskiem, Mariówka 1933.

Wojtasik J., Uwagi księcia Krzysztofa Zbaraskiego, posła wielkiego do Turcji z 1622 roku - O państwie ottomańskim i jego siłach zbrojnych, „Studia i Materiały do Historii Wojskowości" 1961, t. VII, cz. 1, s. 321-346.

Wolff J., Kniaziowie litewsko-ruscy od końca XIV wieku, Warszawa 1895.

Wójcik Z., Dzikie pola w ogniu. O Kozaczyźnie w dawnej Rzeczypospolitej, wyd. 2, Warszawa 1961.

Zabytki sztuki w Polsce, t. I (Kraków, kościół i klasztor OO. Dominikanów), oprac. L. Lepszy i S. Tomkowicz, Kraków 1924.

ZBigniew Anusik

\section{The princes Jerzy and Krzysztof Zbaraski towards the problems of South-Eastern borderlands of Polish Republic in second and third decade of $17^{\text {th }}$ century}

he princes Jerzy and Krzysztof Zbaraski were descendants of the old and
very wealthy magnates family. Their education, wealth and mental qualities
predestined them to play an important role in the political arena. Reluctance on
the part of Sigismund III made, however, that the two brothers found themselves
in the ranks of the opposition. As owners of large estates in the South-Eastern
borderlands, the princes have to be interested in both the situation in Ukraine, as
well as relations with neighboring countries in this region of the Polish Republic.
In the middle of the second decade of the seventeenth century, they fell into
conflict with the hetman Stanislaw Żołkiewski. They believed that the policy of
hetman in borderlands leads to war with Turkey. Zbaraski brothers advocated
the maintenance of peace with the Sultan. Their relation to the Ottoman Empire
did not change until the end of their lives. Maintaining peaceful relations with
Turkey they regarded as one of the priorities of the foreign policy of the Polish
Republic. On the issue of relations with the Crimean Khanate the princes Zbaraski
looked through the prism of Turkish politics. They regarded rulers of Crimea as
performers of the policy of Istanbul and sultan tool to exert pressure on the Polish 
Republic. They were in favor of not to provoke Tartars. But both of them took an active part in the fight against Tartar s invasions. In the fight against the Tatars they were ready to use the help of the Cossacks. In the years 1624-1628 the Zbaraski brothers supported the idea of intervention in the internal affairs of the Crimean Khanate. They believed that fueling the civil war in the Crimea will be in every way beneficial to the interests of the Polish Republic.

Very interesting was also the attitude of Zbaraski brothers to the Cossacks. Both princes believed Cossacks as the rebels, destroyers of internal order and adventurers provoking conflicts with Turkey. They do not accept the policy of tolerance towards Cossacks in the period before Cecora. After Khotyn war they urged Cossacks to stop their trips to the Black Sea. The both brothers quickly recognized the danger posed by an alliance of Orthodox bishops and the Cossacks. They found it as a serious threat to the interests of the Polish Republic in Ukraine. The princes Zbaraski referred to the Cossacks with a sense of superiority and contempt. Appreciated, however, their military force. The Zbaraski brothers advocated a policy of hard hand against the Cossacks. Prince Jerzy has repeatedly stated that the Cossacks do not need any committee, but a sword. However, the princes of Zbaraż feel awe in front of a large and valiant Cossacks army. They feared the destruction of their landed estates. After the conclusion of the Treaty of Kurukove they opted, however, for strict compliance with its terms. Relatively little attention devoted Zbaraski brothers to the situation in the Danubian principalities - Moldavia and Wallachia. But both brothers carefully watched the actions of the ruler of Transylvania - Bethlen Gabor. The paradox seems the fact that after the death of Krzysztof, when he was the most powerful magnate in the South-Eastern borderlands of the Republic, Jerzy Zbaraski was much less interested in the situation in that region. His attention was absorbed at that time by completely different problems. It is in this context to note that even earlier the issue of the problems of the South-Eastern borderlands of Polish Republic were not the main subject of the interest of the Zbaraski brothers. Both princes were politicians who tried to influence the whole, as well internal and foreign policy of the state. Because of that reason they followed and commented all the most important events that have taken place in the Central and Eastern Europe in the second and third decade of the seventeenth century.

Keywords: Polish Republic in the first half of $17^{\text {th }}$ century, South-Eastern borderlands, Jerzy prince Zbaraski, Krzysztof prince Zbaraski, Sigismund III, Turkey, Tatars, Cossacks. 